Portland State University

PDXScholar

Summer 8-11-2014

\title{
Synthesizing the Vertical and the Horizontal: A World-Ecological Analysis of 'the Industrial Revolution', Part I
}

Christopher R. Cox

Portland State University

Follow this and additional works at: https://pdxscholar.library.pdx.edu/open_access_etds

Part of the Economic History Commons

Let us know how access to this document benefits you.

Recommended Citation

Cox, Christopher R., "Synthesizing the Vertical and the Horizontal: A World-Ecological Analysis of 'the Industrial Revolution', Part I" (2014). Dissertations and Theses. Paper 1944.

https://doi.org/10.15760/etd.1943

This Thesis is brought to you for free and open access. It has been accepted for inclusion in Dissertations and Theses by an authorized administrator of PDXScholar. Please contact us if we can make this document more accessible: pdxscholar@pdx.edu. 
Synthesizing the Vertical and the Horizontal:

A World-Ecological Analysis of 'the Industrial Revolution', Part I

by

Christopher R. Cox

\author{
Master of Science \\ in \\ Political Science
}

A thesis in partial fulfillment of the requirements for the degree of

Thesis Committee:

Birol Yesilada, Chair

Joseph Lampert

Kim Williams

Portland State University

2014 


\begin{abstract}
'The Industrial Revolution' is simultaneously one of the most under-examined and overlysimplified concepts in all of social science. One of the ways it is highly under-examined is in the arena of the ecological, particularly through the lens of critical world-history. This paper attempts to analyze the phenomenon through the lens of the world-ecology synthesis, in three distinct phases: First, the history of the conceptualization of the Industrial Revolution is examined at length, paying special attention to the knowledge foundations that determine these conceptualizations. Secondly, I sift out what I believe is the dominant model throughout most of modern and now postmodern history, which I identify as the techno-economic narrative. I then present the main critical worldhistorical challenge to that argument (that the Industrial Revolution was a unified, linear, two-century phenomenon) by outlining the critical interpretations of Fernand Braudel, Immanuel Wallerstein, Giovanni Arrighi, among others, leading a view of industrialization that is over the very long term, or what Braudel referred to as the longue durée. This long-view form of critical historical analysis is unabashedly Marxist, so there is some foray into various pieces of the Marxian canon, pieces that are often left untouched or at the least under-utilized in many politico-economic analyses of environmental history and politico-ecological narratives as well. Thirdly, I attempt to bring this new long-form view of industrialization more firmly into the ecological, but filtering the basic presuppositions of the 'techno-economic' narratives and the Marxist 'critical world-historical' narratives through the presuppositions of Jason W. Moore's
\end{abstract}


world-ecology synthesis. What we arrive at through this filtering process is a very different view of the Industrial Revolution than we are used to hearing about. This is Part I of a much larger research process, one that I intend to bring into the present and future by looking at the development process of the BRICS as the next extension of the Industrial Revolution. What this paper is most concerned with is re-igniting what I think is a valuable debate among theorists, economic historians, and Marxist ecological thinkers, the debate about what exactly this phenomenon was, is, and will be. My small contribution is to re-define it in relationship to its really-existing history, including its antecedents and possible future expansions. 


\section{ACKNOWLEDGEMENTS}

There are several people who have contributed to the evolution of my understanding and interest in the subject matter of this thesis. First and foremost, I would like to thank Dr. Birol Yesilada for two years of unwavering support and guidance in my quest to figure out the answer to his repeated question, "what do you want to know?" It is through his guidance that I learned I need to read more economic history, and in the process I was opened up to the world of critical historical analysis, reading extensively on Marx, Mill,

and eventually Wallerstein. Most importantly, 'Dr. $\mathrm{Y}^{\prime}$ taught me that no question is off limits, as long as I am willing to do the work necessary to engage it. I would not have been able to do the extra-curricular reading necessary for this project if I did not have his help. Secondly, the great world-historian and political economist Dr. Jason W. Moore of Binghamton University has played a central role not only in the obvious sense of alerting me to the developing paradigm of the world-ecology synthesis, but in both the genesis of this project and in my eventually doing a much deeper reading of Marx, Wallerstein, Arrighi, and so many others in the process. The very idea of this paper came as a result of our year-long emails back and forth, often being discussions about Marx and metabolic rift, value, and the 'production of nature'. Without these wonderfully dense conversations, there is no way I would have grown as a thinker as much as I have over the past year. Thirdly, I would also like to thank Dr. Joseph Lampert for his wonderful 
classes, two of which were courses by arrangement that have each played a role in the thinking behind this project. Most notably, his guidance in the area of how we can look at 'gross concepts' without getting too lost in the minutia. I also gained a great deal understanding of how to look at dominant thought paradigms in history by doing a solid reading of the major works of Foucault, as well as all of the major writers on the subject of power in political theory. His gift is in his ability to make a thinker like myself - who is obsessed with gross concepts - not run away screaming, but also realize the gravity of what is being undertaken. I would also like to thank all of the administrative staff in the Department of Political Science and the library staff at Millar Library, who on so many dozens of occasions went and found loads of books for me when my time was running too short to hunt through the shelves. Those young people behind the library counters are simply indispensable. Last, but certainly not least, I thank Dr. Kim Williams for volunteering to read this thesis and Chris Shortell for always being at the ready to offer solid, unvarnished, advice and answers to my questions. 


\section{TABLE OF CONTENTS}

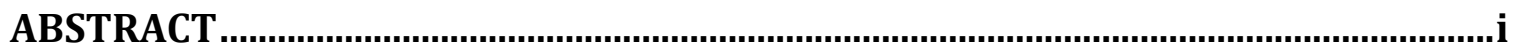

ACKNOWLEDGEMENTS........................................................................................... iii

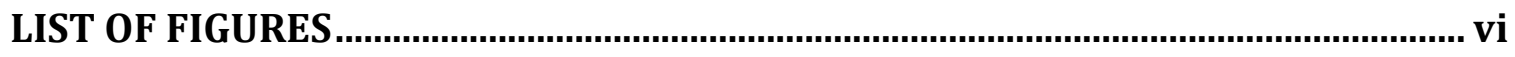

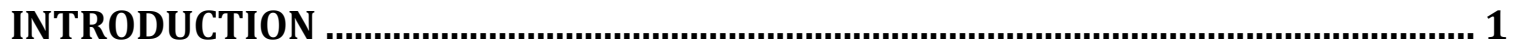

CHAPTER ONE: Tracing the history of the conceptualization of the Industrial

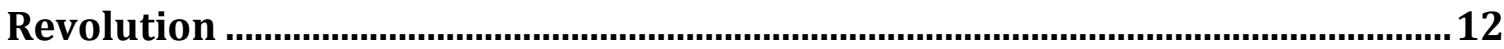

CHAPTER TWO: Industrial Revolution over the Longue Durée..........................41

CHAPTER THREE: Synthesizing the Vertical and the Horizontal ........................64 CHAPTER FOUR: A world-ecological re-defining of the Industrial Revolution 95

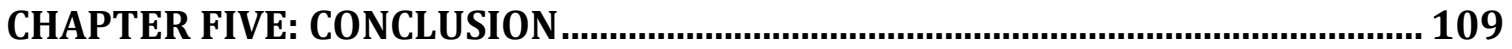

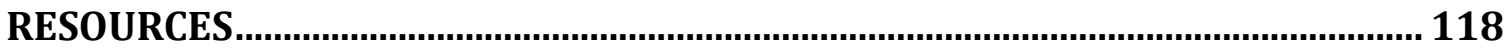




\section{LIST OF FIGURES}

Figure 1..............................................................................106 


\section{INTRODUCTION}

It is pretty obvious that industrialization is not of itself a panacea for man's woes, since it tends to create as many problems as it solves. One by-product of the industrial age has been a considerable fouling of the human environment. Another is the rapid exploitation and expenditure of cheap and available resources. A third is the development of critical social problems among the urbanized masses.

- Paul Shepard (1969)

Historical capitalism over the very long term has been dependent upon the geographical expansion of the capital frontier; expansion vertically, down into the Earth, and horizontally, across the earth's surface. At all points the prize has been cheap labour'power, food, energy, and raw materials, or what Jason W. Moore calls 'the four cheaps' (Moore 2012, 2014b), and what Karl Marx called the 'free gifts of nature' (Marx 1967, III: 745). This illumination allows us to see 'the Industrial Revolution' of 1750-1850 (what will herein be understood as the 'classical Industrial Revolution') not as the savior of men from the suffering of the state of nature and a pre-destined life of poverty and hard work, but as a great expansion of the extractive and exploitative capabilities of an already raging capitalist machine-fix to ecological limitations to economic growth, a revolutions that is still with us today. This paper not only wrestles with the phrase itself, but also the history of industrialization itself, a history that extends far past the middle of the eighteenth century, and begins long before.

\footnotetext{
${ }^{1}$ In this paper I have opted to use only the British spelling of the word 'labour' verses the American English 'labor'. This is only to avoid the annoyance of having both spellings throughout the paper, and also because much of the historical research covered herein is of British or at least European origin where the spelling is most often of the British 'labour'.
} 
'Revolution' enjoys everything but homogeneity of interpretation. It is, as Crane Brinton put it, "one of the looser terms" (1965). 'Industrialism', however, is a term with a lot more agreement across the paradigms of social thought. 'Industrialization', as it will be explained here, is to be understood very simply as the process through which certain items are produced faster - often through changes in production techniques - thereby increasing the availability of produced goods. Put 'industrialization' and 'revolution' together and we find the conceptually muddy waters of the Industrial Revolution. Historians, with the noted exceptions featured herein, have not done much better than the theorists and the economists in regard to rectifying the glaring inconsistencies in how the phenomenon is interpreted and utilized in the development of dominant regimes of politico-economic knowledge. This paper will argue, via the world-ecology framework, that industrialization, seen as ancien regime, not only caused ecological transformations, but utilized them as impetuses, and that the succession of these transformations created, by the time of the fall of feudalism in Europe, a world-system that was capitalist (Moore 2002a/b, 2003; Braudel 1972a, 1972b, 1982; Nef 1964; Marx 1967, 1974). Congruently, the Industrial Revolution can also be seen as the namesake for the series of 'revolutionary' territorial expansions of the capitalist world-system, expansions all dependent upon transcending ecological limitations to economic growth, beginning in roughly 1450 . It is therefore the beginning of the capitalist expansion of the historical industrializations of the past.

The Industrial Revolution is always at once economic, social, political, and crucially, ecological. It is also a subjective social construct that has taken on the role of 
explanatory tool for a long list of conflated socio-economic phenomena. 'Modernity', 'progress', 'advancement', 'growth', even 'evolution' are all terms commonly applied in its use. This paper argues that in order for this increasingly complex phenomenon to be understood better, it must be critically re-examined and met with an adequately complex framework of analysis. I argue that the world-ecology synthesis is one such framework, and possibly the only one in existence, that can accomplish this task, for it views 'environmental history' through the lens of 'historical capitalism as world-ecology', a basic approach that is not dominant in any established methodological or otherwise analytical approach. This central theoretical formation of the world-ecology viewpoint will be examined at length, as well as its potential implications to further research and thinking.

It would be highly suspect to suggest that this one paper will tackle the whole problem of the Industrial Revolution, its lack of definitional soundness, and its myriad inadequate interpretations, in a definitive way. Hence, this project is constructed as the first part in a much larger project that will seek to thoroughly re-problematize the conceptualization of the Industrial Revolution over time and space, with an eye toward what could be termed 'ecological futurism'. ${ }^{2}$ In short, this work is guided toward viewing historical industrialization as a world-ecological process that began long before England was even in existence, and continues unimpeded today. There are thick lines in the ether that separate 'industrialization', 'industrial revolution', and 'the Industrial Revolution'.

\footnotetext{
${ }^{2}$ This is merely meant to convey the idea that futurism, which is actually a branch of history, can be make more useful if it is engaged within an ecological frame as well as the other ways it is more commonly utilized. Futurism is, by design, based on going very far back in history, examining cyclical events in such a way as to give some clarity to how we might envision certain elements of humanity in the future. Futurists, contrary to popular myth, do not only write about the future, but about how we conceptualize the future. Hence, an ecological futurism is self-explanatory in that sense.
} 
Much attention will be spent on the history of the various conceptualizations of the Industrial Revolution, its political and economic drivers, and the socio-ecological implications of its trans-territorial reach. But perhaps most importantly, the challenge inherent in this work is against vulgar linearity, in search of a more ecologically relational way to visualize industrialization over the very long term and into the future. More precisely, to develop a language of analysis that addresses the real historical meaning of industrialization over the very long term, and how that differs from the Industrial Revolution as a flagrant capitalist concept, based on mechanization of already existing industrial enterprises. Further, I will attempt to shed some light upon the ongoing industrialization of the so-called 'developing world', so that we might begin to use our new language to look at ecological futures free of the dominant model of industrialization we have been bombarded with in Western academic pursuits, that of the classical, European two-century model. It is in this sense that I do seek to reclaim, if you will, the phraseology of 'the Industrial Revolution', by adding that it is still in process today. What separates the two interrelated concepts is capitalism.

In order to accomplish this, the basic presuppositions of the world-ecology synthesis - as I have extracted them from the writings of its preeminent practitioner Jason W. Moore - will be closely examined. Those tenets are the direct result of Moore's masterful Marxist dialectical melding of the world-historical models of Fernand Braudel, John U. Nef, E.A. Wrigley, and others, the world-systems thinking of Immanuel Wallerstein and Giovanni Arrighi, and the geospacial analysis of David Harvey, as well as numerous other ecological thinkers. What separates Moore is his willingness to re- 
engage the source literature of Marx and Engels, as well as that of other relational worldhistorians of industrial revolution more generally (Coleman; Hornborg; Bunker; Cipolla; Dean; Cole; et al.), without negating the important pieces of the Marxian canon that are routinely jettisoned by various neo-Marxists. In short, this deep historical canon forms a powerful rope that holds all of this historical-relational knowledge together without losing sight of the importance of the dialectical reasoning that Marxism brings to the table. In the work of the neo-Marxists (Sweezy, Baran, et al) there is a willingness to depart from the dialectic because it is unnecessarily complex, forming what they refer to as 'analytical Marxism'. Marxism without the dialectic is like studying musical theory without looking at the related concepts of harmony and dissonance. The world-ecology framework stems out from a basic premise that we ought not treat the human and the natural as dialectically discrete, but instead dialectically unified, making the crises of accumulation and ecology ineluctably connected and co-productive. This is but one of the reasons I have elected to look at the Industrial Revolution through this lens, a phenomenon that is routinely treated with Cartesian limitations and liberal economic myths that have yet to be shown truthful (the 'steady state', unlimited capital accumulation, the 'invisible hand', etc).

Perhaps the most important question I must address in this introductory statement is why the Industrial Revolution? Why not just capitalism itself? Why not write a paper about the rise of capitalism as an ecological phenomenon? The reason is simple. By looking at the phenomenon through a world-ecology lens, we begin to see, more clearly than ever, that capitalism might better be analyzed as a product of socio-ecological 
transformation over time and space (Moore 2002a). More precisely, industrialism itself, going all the way back to water as a source of power, has always manifested as a result of ecological transformations caused by the economic and productive complications brought about by the concentration of people and processes into certain geographical locales, what Marx referred to as 'breaks' in the social metabolism or Stoffwechsel (Marx 1967b, 1972d, 1972c). While Moore has done copious amounts of writing that critically reinterprets economic history as environmental history - laying the groundwork for this project - he has yet to produce a work that is solely focused upon the Industrial Revolution and its connected epistemic lines, viewed through this framework. My aim is to add that crucial element to the growing world-ecology literature. Lewontin and Levins, in their irreverent style, perfectly surmise the natural philosophical piece to both this paper and to the world-ecology framework:

Our understanding of nature is deeply constrained by the language we need in talking about it, a language that is itself the result, as well as the replicator, of long-standing ideological practice. All of science, even "radical" science, is plagued by dichotomies that seem unavoidable because of the very words that are available to us: organism/environment, nature/nurture, psychological/physical, deterministic/random, social/individual, dependent/independent. A remarkable fraction of the radical reanalysis of nature that we ourselves have engaged in has revolved around a struggle to cut through the obfuscations that have arisen from those false oppositions (2007: 23).

It is in this sense that the world-ecology project is a radical reanalysis of industrialization and historical capitalism over the long durée of world-history, and for that matter politico-economic theory. This paper is an attempt to add some clarity to the Industrial Revolution by actively negating those binaries wherever possible, taking us hopefully ever closer to the transcendence of the dead language of historical 'industrial revolutions' into a living language of ecological futures. It's central thesis is that the Industrial 
Revolution would hold vastly more explanatory power, as a concept, if we were to situate it within a more honest, historically holistic position in world-history. More precisely, I maintain that the common wisdom that surrounds the Industrial Revolution - that it occurred roughly between the years $1750-1850$ - is flawed, and that this time period is more accurately referred to as an episode of great intensification of a world-ecological event that began with the fall of feudalism in Europe and the appearance of a European capitalist world-economy in the long sixteenth century. Through many more successive expansions of the capital frontier, both vertically (down into the earth) and horizontally (out across the surface of the earth), the European world-economy eventually grew to what it is today, what we will refer to here as the capitalist worldecology.

\section{The Organization of the Paper}

This thesis will be argued in three distinct stages. In chapter one, the history of the defining of the Industrial Revolution will be closely looked at. This is effectively the epistemological history of the phenomenon up until the arrival of Braudel and then Wallerstein, who re-defined the concept in their work. The writings of Arnold Toynbee (the supposed inventor of the term Industrial Revolution), Adam Smith, Thomas Malthus, and David Ricardo will be looked at as the foundation to the more liberal economistic narrative of the Industrial Revolution, leading to what will be argued is the flawed assumption that it was, and remains, a unified, progressive phenomenon that happened within a specified box of time and space. We will call this the techno-economic 
narrative. Additionally, the more critical writings of Sir David Carlyle and Charles Austin Beard will be looked to for then-contemporary critiques of the dominant view of the time. As lacking as these narratives of the phenomenon are, on so many fronts, they provide much of the bases for the most accepted common wisdoms that surround the Industrial Revolution, and this techno-economic narrative is still the dominant one today.

In the first part of Chapter Two, the work of Braudel, Wallerstein, and Arrighi, among a few others, will be looked at through the prism of what I have deemed the beginning of the 're-defining of the Industrial Revolution'. Wallerstein, in particular, added a tremendous set of tools for the examination of the Industrial Revolution, because his work made irreducibly clear that the rise of the capitalist world-system is synonymous with the rise of the geographical expansionist tendencies of the capitalist mode of production, tendencies that were greatly exaggerated in the eighteenth and nineteenth centuries. What he did was identify the transition from feudalism to capitalism as a "socio-physical conjuncture," (1974: 35) something nobody until that point had done. According to Moore, "In Wallerstein's hands, modern relations of capital and class shaped, and in turn were shaped by, transformations of the earth" (Moore 2002a). This is in very stark contrast to the environmental determinist approach to environmental history (Diamond 1997; Jones 1987; Landes 1998) that leaves little or no room for systemic critique. In doing this critical revision of historical capitalism, Wallerstein and others redefine the phenomenon over the very long term, what Braudel called the longue durée. By adding another five-hundred years to the study of the Industrial Revolution, or the 
concept of 'industrial revolution' more broadly, we can begin to understand the present conjuncture with more clarity.

The long view of the Industrial Revolution allows us to connect the rise of the capitalist world-system, or better yet, the appearance of said system, to the fall of feudalism. It is with this added historical clarity that I argue the Industrial Revolution must have a start date closer to this point of convergence than that of the two-century view that is usually endorsed by mainstream economic history, as well as environmental history. With that in mind, the second part of chapter two will include some of the critical reworking of the Industrial Revolution that has come from the contributions of the critical world-historians, such as Cipolla, Hornborg, Coleman, Cole, McNeill, MartinezAlier, Bunker, and Hartwell, among others.

Crucially, in the first part of Chapter Three I will attempt to bring the Industrial Revolution into the realm of the ecological by engaging a post-Cartesian ontology of 'humanity in nature' versus 'humanity and nature', a key presupposition of the worldecology viewpoint. Furthermore, this approach allows us to merge, or dialectically examine, both the economic liberalist narratives of the Industrial Revolution (Smith, Malthus, Ricardo, Toynbee, Landes, Mokyr, et al.) and the extra-ecological relational narratives (Wrigley 1988; Taylor 1970; Dowd 1971; Arrighi 1994,1998; Pomerantz 2000; Marx 1967a, 1972a, 1972b), by synthesizing the 'vertical' and 'horizontal' modes of expansion of the capital frontier.

The argument that will be made in Chapter Four is that by sifting the presuppositions of the two competing narratives of the Industrial Revolution - each with 
their redeeming points and their disqualifying points - through the set of presuppositions of the world-ecology synthesis, what we are left with is a re-definition of the Industrial Revolution that is drastically different from all preceding narratives.

My guiding assumption is that this critical re-definition can hold great potential for developing more accurate speculation about future socio-ecological transformations over time and space. Perhaps it goes without saying that there are more narratives of the Industrial Revolution than the ones I have extracted here, but as will be explained in the coming chapters, the insinuation is that these are two of the most dominant narratives that exist. And by filtering them through the world-ecology synthesis, we are able to then begin the process of giving a more historically accurate and ecologically relevant definition, one that can serve a larger purpose in future politico-economic analysis, for its temporality changes to become both current and futurist. After all, is not Brazil in the midst of an 'industrial revolution' as we speak? Or might we better say in the midst of the continuance of the Industrial Revolution? Is not India? China? And what might we say about the temporal-spatial advent of the digitization of capital? Questions of this sort will be addressed in the final chapter of the paper.

Lastly, by making the leap to a post-Cartesian view of the human/nature divide, or the 'society/nature binary' as it is often called, the historicity of the Industrial Revolution as it is usually interpreted becomes suspect. Was not the wheel an industrialization revolution? The use of water for power? This is the terrain on which Braudel and Wallerstein cause us to question the very idea of industrialization itself, immediately rendering the use of "the" as suspect, and the use of 'revolution' as problematic, but not 
unjustified. However, for our purposes, we will not suggest doing away with the Instead, we will simply expand, more accurately, upon why the is used. If we include all of these previous industrializations in the record of the historical development of capitalism, how is the Industrial Revolution affected as a social scientific phenomenon? That, I argue, is a key question of historical significance.

This paper is Part I of what will be a much larger project, a project that I argue is of taproot importance to our further understanding of the current global crises - crises that are all simultaneously political, social, and ecological. The world-ecology synthesis is a budding paradigm of its own that contains within it all the tools to develop a theoretical praxis for the analysis of historical capitalism free of the many faults of the dominant narratives of the Industrial Revolution outlined herein. 


\section{CHAPTER ONE: Tracing the history of the conceptualization of the Industrial Revolution}

Like Jelly Roll Morton's infamous self-designation as 'the inventor of jazz', it is usually Toynbee who is most often pointed to as the inventor of the Industrial Revolution, originating in his famous Lectures on the Industrial Revolution of the Eighteenth Century in England. This is, however, far from correct, just as Morton's proclamation, which really belongs to the slave musicians of New Orleans. Nearly forty years before Toynbee's use of the term, none other than Friedrich Engels used the phrase in explaining a social and economic change of historical significance 'with the full force of a revolutionary event' (Himmelfarb 1984: 282). Engels did this first in his essay The Condition of England, which was published in 1844 and then again in 1845 as part of his groundbreaking book The Condition of the Working Class in England, an important precursor to much of his work that would later come in concert with Karl Marx, together forming much of the nineteenth century antithesis to the dominant thesis of 'economic liberalism', which we will engage momentarily. Though his work was not translated into English for another forty years, it is Engels that brought to life the idea of the Industrial Revolution as a whipping post for the political left (Coleman 1992). However, before we can get into Marx and Engels and the other Marxist/Socialist and/or sociopolitical arguments against the sunshiny linear economistic views of the Industrial Revolution we must first deal with the history of the term itself, as shown by its most dominant historical narratives. 
While Engels might be the first to use the phrase extensively, and in an overtly sociopolitical way, he was certainly not the first ever to use the phrase, or to coin it. That distinction goes to the French, during the political revolutions of 1789 and 1830, where the new machinery used for cotton-spinning (the 'spinning jenny') and Watts' invention of the steam engine in 1780 were engaged in an article with the title 'Grande Révolution Industriellè' (Bezanson 1922). There were several others who used the phrase (Blanqui, Briavoinne, et al.), but it was really Engels who first dug into the mythology of the Industrial Revolution. The Condition of the Working Class was the first of its kind, a critical interpretation of the actually existing conditions of labourers during the rise of industrial capitalist society, particularly in the factories of Manchester, England - the site of the most egregious expropriation of human nature documented by that point in the historical record. While his contribution is well-documented and respected today it was certainly not Engels who got to define the phenomenon. For better for worse, it was Toynbee.

It was 'principled social critique' (Shapiro 1989) that eventually gave rise to the critical thinking of the great Charles Austin Beard, who remarked, "Though the Industrial Revolution opened the way for the production of the means of life without the consumption of all of human energy, man, startled and stunned by the sudden changes in the methods of working and living, was unable to organise his life so that all might share in the benefits of the new inventions... It called into existence suddenly the factory towns, with the want of corporate life, their vile sanitary conditions, and filthy hovels... it seemed as if man had become utterly powerless to adjust himself to the new conditions, 
to conquer and control them as he had the forces of Nature" (Beard 1901: 2-3), speaking of it as an 'industrial convulsion', and a 'demolition of the old order'. Beard (with the great assistance of his wife Mary) is a great exemplar of the fact that not all of English humanity was behind the great acceleration that the Industrial Revolution represented to most. Another important then current contribution to the critical interpretation of the Industrial Revolution is found in the writing of Sir David Carlyle, a renegade thinker of the day who openly challenged many of the defining contributions of Adam Smith, such as the principle of 'supply and demand' and his relative inattention to the issue of labour and wages (Bodwitch and Ramsland 1961, 96). As we can see from these two rather irreverent thinkers, the Industrial Revolution was not a unified event, in the sense that all of society in England was whole-heartedly behind it. To the contrary, one could easily argue that it was the strategic opinion-making of an extremely privileged minority of the time. the captains of industry wrote the narrative to support the ends of capital accumulation, liberation from societal obligations, and all the other liberal notions of the nineteenth century capitalist mindset. As usual it was a case of the wealthy few writing then current history as though the poor and the indigent did not exist.

Regardless of when the term first came to be, and who first spoke it, to speak of the Industrial Revolution is to speak at once about a socio-economic phenomenon that brings with it an implied, but far from precise definition, and of something horribly under-examined in economic and world-history. And it might be stated that any worthy politico-economic theory becomes unworthy if it employs a manufactured historicity that supports false notions of modernity. How is it possible that a phenomenon as influential 
as the Industrial Revolution can remain so unsettled in both its definitional and temporal soundness? This is one of the key questions that arose when I began researching the phenomenon. Even a terse reading of economic history brings forward a vision of the Industrial Revolution that is linear in scope, geographically unified, and generally understood as a causal-mechanistic story of how the modern (meaning 'industrialized') world came to be (Toynbee 1956; Hartwell 1967a; Landes 1969; Thompson 1973; Mokyr 1990), and the backstory that the postmodern era rests upon (Apter 1965).

The inevitable starting place for tracing the history of the conceptualization of the Industrial Revolution is with a critical look at the differences between three distinct terms: industrialization - industrial revolution - the Industrial Revolution. Neither one of the three are the same, yet each contains a bit of the other two. To industrialize is merely to invent methods of producing the means of subsistence at a faster, or at least in a more efficient (in terms of human or animal labour power) way. Lynne White Jr. gives a great account of industrialization as technological invention by pointing out that, "Between the first half of the 6th century and the end of the 9th century Northern Europe created or received a series of inventions which quickly coalesced into an entirely novel system of agriculture" (White, Jr. 1963: 277). The inventions White wrote of are "the heavy plough, the three-field rotation system, open fields for cattle, the modern harness and horseshoe," according to Wallerstein (2011: 52-53). In this sense, the invention of the water wheel, or the use of water to power wooden machines, was also a form of industrialization, as was the harnessing of fire for cooking, and the wheel for transport of heavy weight. Of course, we run the risk of building a kind of simplistic linear logic akin 
to the 'progression of man' over time and space with this kind of chronological tale of important inventions, i.e. industrializations. However, the point here is to show that the word industrialization is a relatively new word for an ancien regime. In other words, industrialization is not necessarily the marker of impending economic growth, in either the short or long term. The invention of the pulley system, for example, could not logically be argued as an industrialization that led to great expansions of wealth, but it could be pointed to as a great expander of the quality of life of the people who now could get their water from a well, versus walking for miles with goat bellies full to the brim, slung over their shoulders. In the least, even these early industrializations can at least be credited with increased life and space-making capabilities, making them not altogether different from other later industrializations. The main difference may simply lie in that they were not made under specifically capitalist arrangements of society. That would not come until the fall of European feudalism, as I will show in the next few chapters.

There is a great obsession in the writing of history, as it relates to the Industrial Revolution, an obsession with the concept of economic growth. The idea of industrialization is as ancient as the human need for invention, which we all know is the proverbial outcome of necessity. When the word revolution is added, we find not a view of collective social unrest for systemic legitimacy, or even a crying out for society to progress past its current conditions, but rapid economic growth. Marx and Engels (also quite linear in their understanding of the Industrial Revolution as a tool for increasing the efficiency of production at the expense of human labour power) wrote in the Communist Manifesto that, following the downfall of feudalism, "Manufacturing no longer was able 
to keep up with [this] growth (of population). Then, steam and machinery revolutionized industrial production" (Marx and Engels 1964: 59)(emphases added). Like the early Marx and Engels, most of the writing of the day, and for that matter the writing of today, in this regard, was centered on the idea of industrialization as a way to engage economic growth at a rate that was not possible in the old agrarian mode of production; not possible primarily because of ecological limitations to the accumulation of capital past a certain point. Hence, the word 'revolution' immediately takes on an economic ethos. I argue this is not the way 'revolution' should be interpreted in regard to industrialization, for what makes a particular industrialization revolutionary is in the eye of the beholder. If we go far enough back into history, the linear thesis fails to be explanatory. Production through factory organization, various sources of power in manufacturing, divisions of labour, and other factors commonly understood to be intrinsic to industrial revolution are found in Europe and many other regions long before the idea even made it into common parlance. In fact, as the great historian G.N. Clark pointed out "Historians can find an industrial revolution under almost every stone" (1953). In response to such sentiments, Allan Thompson suggests, "If the term is to be useful it must apply to a unique phase of the economic growth of a particular country" (Thompson 1973: 26). Thompson, like others obsessed with growth as the main indicator of what constitutes an industrial revolution, defines the confines of industrial revolution thusly:

In the economic sphere we are simply using a different time perspective. In economic terms the period of the classical industrial revolution was a time when economic advance produced a much more fundamental change in man's economic life than any other period of similar span, and in that sense it is a revolution - an economic revolution (emphasis added) (Thompson 1973: 26). 
And with that quote, we have uncovered one of the most salient problems in identifying an adequate definition of the Industrial Revolution - the usually unwritten rule that what is really being teased out is an 'economic revolution', not a revolution in the socioecological, political, or psychosocial aspects of the process of production and human labour therein. This leaves us with the view that industrial revolutions are primarily economic, and that basic view is what I argue has led to the capitalization - pun not intended - of the Industrial Revolution, and the subsequent time-bracketing of roughly 1750-1850. In the following chapters I will seek to clarify that what makes the industrializations of the two-century period normally depicted as the Industrial Revolution unique is that they were specifically capitalist. It was, therefore, a capitalist production revolution, one that is still ongoing.

Thompson is not alone in his addiction to seeing economic growth dynamics as the most defining characteristic of the Industrial Revolution. E.A. Wrigley, though far more nuanced in his interpretation, adhering much more to the relational form of history, bases much of his analysis on the writings of the classical economists, most notably Adam Smith. He writes:

The economic growth process that Adam Smith described was indeed a cumulative, progressive and unitary phenomenon, which embraced a variety of changes in political, legal and social structures and attitudes as well as economic change. But for reasons cogently argued by smith himself and his successors, the momentum of growth was to be expected to peter out after a time, arrested by changes endogenous to the growth process itself, and giving rise in due course to the supervention of the stationary state (Wrigley 1999: 3).

The above quote gives rise to the question of the periodization of the Industrial

Revolution. Is it a phenomenon largely constitutive of a relatively short two-century 'industrial convulsion' (Beard 1901), or is it both older and more current than that, 
starting much earlier and still under way? That is one of the central questions of this paper, and it cannot be answered without this exercise in identifying the origins of what we can call the Classical Industrial Revolution, or what I will refer to later as the linear two-century techno-economic view, one constructed upon the two presuppositions of economic growth and technological advancement as both impetuses and indicators. Just as Landes argued that "The heart of the revolution was an interrelated succession of technological changes" (Landes 1969: 2), Mokyr's technology cum evolutionary approach to the history of the Industrial Revolution also hinges upon the intersection of growth and technological advance, arguing that "some cultural, scientific, or technological ideas catch on because in some way they suit the needs of society in much the same way as some mutations are retained by natural selection for perpetuation" (1990: 276). Neither Mokyr nor Landes spends nearly enough time hashing out the many antecedents of the Industrial Revolution, and when they do, they usually argue they are relatively unconnected. This is where Thompson attempts to redeem himself by asserting that - and one can scarcely argue against this - that there was a 'revolutionary phase' of the process of industrialization writ large. However, he dares not dig into those antecedents, for they will surely negate the neat boxes of time he and others have set up as the era of the Industrial Revolution. Further, if the antecedent history is included, the phenomenon begins to look much less 'revolutionary', pointing to 'industrial revolution' as a process, and not situation. I will address this in greater detail momentarily.

This discussion of the use of the term revolution is important and demands a little more attention, for it factors greatly into the economic liberalism that is so foundational 
to the linear techno-economic treatment of historical capitalism and industrialization. The strongest challenge to the use of the phraseology of "industrial revolution" comes from the world-historians, who claim that the Industrial Revolution, particularly in England, was only possible because of the nearly 500-year history of social, political, economic, and ecological inventions and transformations along the way. This argument will find much support later in this paper. Thompson, for example, agrees that, "There were, indeed, antecedent conditions which were essential to the industrial revolution, and some of these developed over generations or centuries" (Thompson 1973: 27), but he takes the familiar escape route of arguing that if we are to take historical antecedents as the markers for the start of revolutionary periods, we are engaging in the 'fallacy' of the "implicit assumption that it is impossible to distinguish between antecedents and the 'revolution'" (Ibid). This is a clear conceptual problem for Thompson, and for that matter so many others who argue for a cliometric ${ }^{3}$ history of the Industrial Revolution, for they are running dangerously close to equating their own 'economic revolution' with social and political revolution. The above argument holds water when talking about sociopolitical revolutions, for there is clearly a point at which a revolutionary movement becomes in fact a revolution, but the water leaks out fast when we are talking about an 'industrial revolution', for that requires, among other things, a very long succession of socioecological transformations over time and space, without which their 'economic revolution' stands no chance. This is also to say nothing of the roles of slavery (Williams 1994), imperialism (Williams 1980), and accumulation of capital by dispossession

\footnotetext{
${ }^{3}$ This simply means an economics-based analysis, versus a social or purely historical-relational.
} 
(Harvey 2003; Arrighi 2011) in the development of the capitalist mode of production that made the supposed 'economic revolution' inherent in the Industrial Revolution possible.

A much better argument for the rescuing of the term 'revolution' as it is dealt with here comes from the often-overlooked work of H. L. Beales. He argued that where the Industrial Revolution is concerned:

The changes which are described as revolutionary rose spontaneously from ordinary economic practice, and they were constructive in that they gave an increased power of satisfying wants. It is impossible, too, to find a beginning or an ending of these developments. The inventions on which rested the enlargement of industrial enterprise established themselves only slowly. New economic ideas, revised economic policies, modified economic relationships, all were shaped gradually (Beales 1958: 28) (emphasis added).

It is clearly stated by Beales that his temporality of the Industrial Revolution was indeed 1750-1850, an assertion that this paper will take major issue with. However, where so many other historians have allowed that limitation to lead to a 'time-chart' (Thompson 1973) view of the development of the Industrial Revolution, in turn leading to a vulgarly simplistic economic analysis of the phenomena - usually exemplified by the fetishization of growth - Beales retains his critical mind. He argues for a view of the term revolution that is not equated with suddenness and speed, but with degree of change. In stark contrast to Thompson, he is essentially arguing there is no such thing as an 'economic revolution', for economics must by necessity be 'shaped gradually'. He also takes issue with the idea of equating political revolution, "the substitution of one system of legality for another" (Beales 1958: 30), which can be done quite fast, with industrial revolution, which he seems to argue is over a much longer period of time. But does this mean that the term revolution should be dropped from the title of the phenomenon? Consider that before the Industrial Revolution, or at least before the period 1750-1850 (as Beales sees 
it) "agriculture provided the economic basis of English life: after it, the basis was industry, extractive and manufacturing... A civilization based on the plough and the pasture perished - in its place stood a new order, resting, perhaps dangerously, on coal, iron and imported textile materials" (Ibid). This argument mustn't be dismissed. It ought to cause us to think deeply about the dominant narrative of the Industrial Revolution as a sudden, dramatic change. While it surely may have seemed that way for many in that day, we have the benefit of hindsight and therefore, of future-sight. There was no magnificently altered system of production already in place to provide that suddenness of change. To the contrary, what we might argue was suddenly changed was the viewpoints of the owners of capital. The vast majority of society was not involved with the process of industrialization in any way similar to the way the industrial class was.

\section{The Rise of Economic Liberalism}

Economic liberalism, for all intents and purposes, is the ideological canvass on which the concept under examination was, and continues to be painted by most economic and otherwise historians. While much issue will be taken with the economic liberalist worldview, I will contend that the rise of economic liberalism forms a duet with the rise of industrialism, or industrialized man. David Fusfeld tells us that economic liberalism is a theoretical movement that grew out of the short-lived but influential "physiocratic interlude" headed up by François Quesnay (1674-1774), the de facto king of the antimercantilists. He writes, in his masterful work of economic history the Age of the Economist, that the economic liberals "based their argument on the social theory that 
individual motives, however selfish they might be, resulted in benefits to society as a whole" (2002). He argues that, "From small beginnings in the late seventeenth and early eighteenth centuries, it became the mainstream of economic thought in the nineteenth century and lives on today as the classic capitalist ideology" (2002: 19), only now it is the slowly globalizing movement of American neoliberalism. The simple fact that economic liberalism is an ideology, as opposed to a theory or in some way based on historical fact, is of profound importance to the work at hand, for it plays a role in the development of the ideation of the Industrial Revolution that cannot be underestimated. The most basic tenets of economic liberalism inform most of the basic presuppositions of the linear economistic narrative that still dominates the discourse today. These basic tenets can be brought to the surface through considering the thinking of Adam Smith, Thomas Malthus, and David Ricardo, the three key figures of the rise of economic liberalism in the modern age.

What lies at the center of the argument of Adam Smith and the economic liberalism viewpoint in general, as it relates to the project at hand, is his labour theory of value. This was the first appearance of the central idea that the source of all wealth was not in fact in trade and agriculture - the source for all the earlier economic viewpoints, as well as the focus of many later Marxist rebuttals - "it was through individual effort, they argued, that production takes place and the wherewithal to satisfy human needs is provided" (Fusfeld 2002: 21). Smith's now infamous example of the 'division of labour' is in the "trade of the pin-maker" (Bodwitch and Ramsland 1961: 13). In his most 
renowned work An Inquiry Into the Wealth of Nations Smith outlines this division as follows:

One man draw out the wire, another straights it, a third cuts it, a fourth points it, a fifth grinds it at the top for receiving the head; to make the head requires two or three distinct operations; to put it on, is a peculiar business, to whiten the pins is another; it is even a trade by itself to put them into the paper; and the important business of making a pin is, in this manner, divided into about eighteen distinct operations, which, in some manufactories, are all performed by distinct hands, though in others the same man will sometimes perform two or three of them (Ibid).

The above quote illustrates the basic point, but the larger point, the head of the pin if you will, lies in the following explanation by Smith, namely that, "There are in a pound upwards of four thousand pins of a middling size. Those ten persons, therefore, could make among them upwards of forty-eight thousand pins in a day. Each person, therefore, making a tenth part of forty-eight thousand pins, might be considered as making four thousand eight hundred pins in a day" (Ibid). Herein lies the most fatal of all liberal economic assumptions - that this remarkable increase in the productive capacity of human muscle power, aided by machines, is only and always a good thing. This is the root of the modernist notion that more is better; that efficiency of production trumps quality, both in goods and in life!

In other works by Smith he takes on some of the ethical issues of the division of labour under the capitalist mode of production, but never to the point of questioning its necessity or its justness. As Hobsbawm put it, "The early observers" of the Industrial Revolution - which we must take to be Smith among others - "who concentrated their attention on the qualitatively new ways of producing - the machines, the factory system and the rest - had the right instinct, though they sometimes followed it too uncritically" (Hobsbawm 1999: 12). One could certainly call Hobsbawm's treatment a little too light- 
handed. Laissez-faire, or the principle of reliance upon the market to solve the bulk of societal problems, was to become, by the middle of the nineteenth century in Britain, as close to a form of government policy "as has ever been practicable in a modern state... Government was small and comparatively cheap, and as time went on it became even cheaper by comparison with other states" (Ibid: 211-212). Smith is given a more charitable treatment by Mathias, who focuses upon Smith's suggestion that "expansion was limited by the powers of 'accumulation'; and that capital was created by 'parsimony' sparing resources from consumption" (Mathias 2011: 88). It is no secret that Smith was not the grotesque capitalist that he is often made out to be, for he did believe in the steady state, an ongoing state of affairs that allows the economy to grow at a rate that is manageable over the long term, avoiding the overuse of 'necessary commodities', which he defined as "not only the commodities which are indispensably necessary for the support of life; but whatever the custom of the country renders it indecent for creditable people, even of the lowest order, to be without" (Smith 1776: Book V, chapter 2). Everyone did not love Smith at the time. In the immortal words of Sir David Carlyle, one of the few relative contemporaries to challenge the Smithian view, argued that, "The world, with its Wealth of Nations, supply-and-demand and suchlike, has of late days been terribly inattentive to that question of work and wages" (Bodwitch and Ramsland 1961, 96). It should be noted as well that Carlyle was far from the only dissenting voice in the rise of the industrial men and their connected organization of a society of workers, making up what has often been called the 'workshop of the world'. Let us not completely throw Mr. Smith off the train. Smith was not immune to the sufferings of the 
working class. A rarely cited piece in The Wealth of Nations goes like this: "We have no acts of Parliament against combining to lower the price of work; but many against combining to raise it" (Smith 1776: Chapter 8). He also argued that there is floor through which no workingman must fall.

A man must always live by his work, and his wages must at least be sufficient to maintain him. They must even upon most occasions be somewhat more; otherwise it would be impossible for him to bring up a family, and the race of such workmen could not last beyond the first generation (Ibid).

It is, however, the Laissez-faire contribution that Smith is best known, for better or for worse, in the minds of most who came after him. Economists and other thinkers have, since the rise of this Smithian project, continuously reified its logic whenever and however possible, into the current neoliberal tendencies of global capitalistic empire. It is another example of the often-unexpected consequences of one man's thoughts becoming the propaganda of another's intention. T.S. Ashton, for example, writing in 1948 in rebuttal to the Marxist or socialist movements of the day, stated:

It is a truism, however, that the standard of life of a nation is raised when fewer people are needed to provide the means of subsistence. Many of those who were divorced from the soil (as the stereotyped phrase goes) were free to devote themselves to other activities: it was precisely because enclosure released (or drove) men from the land that is to be counted among the processes that led to the industrial revolution, with the higher standards of consumption that this brought with it (Ashton 1948: 26).

This is the most vulgar form of capitalist logic on high display. Ashton was to become one of the most overtly supportive public intellectuals of all the tenets that even Smith argued were unjust in the process of the evolution of capitalist production.

Not only did Ashton assert the virtues of the market mentality, he actively denounced those who challenged it, as can be seen from the flippant tone of the parenthetical pieces of the above quote. Furthermore, his rather uncritical support, even in 1948, of the process of the 'enclosure' of the open fields policies of the earlier agrarian 
arrangements shows his cards. He even went as far as to call Jethro Tull, the inventor of the horse-drawn plow, a 'crank' who "set back the movement to progressive farming in many parts of England" (Ashton 1948: 27). It is interesting to note here that it was indeed the deep plowing of the horse-drawn sort that is responsible for the farmers of the English highlands uprooting, by accident, the first seams of coal and iron ore, spawning the first mining towns of England (Nef 1967). This must make us wonder about the historicity of Ashton's claim about Tull, but it does not take away the veracity of the argument Ashton levied against the near mythical figure. Ultimately, Tull was one of the first agricultural thinkers to challenge the idea of crop rotation, in favor of what he called 'deep working' of the soil. It is actually well known now that deep working of the soil is indeed better for the soil in the long run. Tull claimed that through this method he was able to grow wheat for thirteen successive years on the same land, a process that was, according to Ashton, "economical of seed, but wasteful of land" (Ashton 1948: 27). The Ashton argument points directly to the influence of the agricultural implications of the economic liberalist contention, namely that the land should be made to produce more, not produce better, and that it should produce more at an increasingly faster rate. Hobsbawm takes on the issue of efficiency of production over quality of production, by pointing out the following, and it is worthy of the space:

It is often assumed that an economy of private enterprise has an automatic bias towards innovation, but this is not so. It has a bias only towards profit. It will revolutionize manufactures only if greater profits are to be made in this way than otherwise. But in pre-industrial societies this is hardly ever the case. The available and prospective market - and it is the market which determines what a businessman produces - consists of the rich, who require luxury goods in small quantities, but with a high profit-margin per sale, and the poor, who - if they are in the market economy at all, and do not produce their own consumer goods domestically or locally - have little money, are unaccustomed to novelties and suspicious of them, be concentrated in cities or accessible to national 
manufacturers... The sound businessman, if he has any choice, will produce very expensive jewelled timepieces for aristocrats rather than cheap wrist-watches, and the more expensive the process of launching revolutionary cheap goods, the more he will hesitate to risk his money it (Hobsbawm 2011: 17-18).

These 'revolutionary cheap goods' first came in the form of the industrialization of agriculture, the direct opposite intentions Tull and other agrarians of the day were proposing.

We learned quickly, after the onset of the Industrial Revolution - as it is being discussed now - that population growth, among many other reasons, made Smith's steady state economy a virtual impossibility. Thomas Malthus was a causal-mechanist and binary thinker of the highest degree, making his pronouncements extremely limited in applicability. Jason W. Moore reflects, " The problem with Malthus is that he removes scarcity from history. If you remove scarcity from the actually existing relations of power and production, then scarcity becomes abstract" (Moore 2011a). Nevertheless, his thinking did open the door to one of the most profoundly difficult issues of the Industrial Revolution and economic growth in general, changes in population. Knowing nothing about the business world, he was educated by highly paid private tutors, thanks to his upbringing in Surrey as the son of an "English country gentleman" (Bodwitch and Ramsland 1961, 49). He states, in Book I of his Essay on the Principle of Population as it affects the Future Improvement of Society (1798):

It has been said, that the great question is now at issue, whether man shall henceforth start forwards with accelerated velocity towards illimitable, and hitherto unconceived improvement; or be condemned to a perpetual oscillation between happiness and misery, and after every effort remains still at an immeasurable distance from the wished-for goal (Ibid, 49-50).

It could rightly be argued, from the vantage point of current history, that the later part of the quote was the unfortunate truth, but we will not hash that out here. Malthus was 
obsessed with the basic reality that population "increases in a geometrical ratio," while "subsistence only increases in an arithmetical ratio" (Ibid, 51). In short, food supplies will never keep pace with population growth, unless population growth keeps pace with ecological regeneration. It was, according to Malthus, impossible for man to escape his two "postulata," namely that food is inescapably necessary for human survival, and secondly, that "the passion between the sexes is necessary, and will remain nearly in its present state" (Ibid). In short, we are all doomed to overpopulation and the weakest among us are doomed to a miserable fate. Put far more bluntly, the rich get richer and the poor keep having babies. The Malthusian argument leads to a ugly worldview of prosper or die. And this is made dreadfully clear by his rather inhumane position regarding the poor laws of the late eighteenth century, arguing that if society was to collectively take from the rich to feed the poor, as a measure of controlling the inevitable decline of humanity over time by allowing for the poor a cut of the rich man's meat, the inevitable outcome would be thus: "The competition among the buyers in the market of meat would rapidly raise the price from eight pence or nine pence to two or three shillings in the pound, and the commodity would not be divided among many more than it is at present" (Ibid, 59-60). Sadly, this statement was quite correct. However, the Malthusian view is therefore devoid of any ethical concern for how to stem the tide of overpopulation and its related problems of food scarcity through institutional means. Impossibility for Malthus was the need for social and political revolution for others. Perhaps the most damning account of the Malthusian solution to the rising economic, and increasingly ecological, crises of the period, comes from Fusfeld, who states: 
Like all good conservatives in a time when serious problems abound, he found the cause of the crisis not in any recent developments or changes that might be amended by policy actions, but in large forces over which governments have little or no control (Fusfeld 2001, 40).

Malthus is still very much with us today in the deep green ecological arguments of the anti-civilizationists, or what is sometimes referred to as 'anarcho-primitivism' (Jensen 2006; Zerzan 1999; et al.), and the anti-anthropocentric ecological theorists who argue that humanity itself is to blame for the ecological crises of the current age, and that therefore humans have only one recourse for righting the course of what Fuller called 'spaceship earth': stop procreating and stop consuming. This kind of socialenvironmental determinism is as much a part of the problem as it is the solution. It is a theoretical and activist space wrought with pitfalls, but does offer much in the way of future stewardship of the planet that humanity at large can participate in. It is beyond the scope of this paper, obviously, to engage with that paradigm, but it should be noted that the populationist approach to the problem of ecosystemic degradation most certainly confuses outcomes with the origins of destructive processes. From an anti-civilizational perspective, the Industrial Revolution is the point at which humanity, undifferentiated, became the greatest threat to the earth system; a view that fits nicely with the argument of the Anthropocene put forward by geological chemist Paul Crutzen and others. ${ }^{4}$

\footnotetext{
4 The Anthropocene serves as a prime example of a dominant concept that tacitly presupposes the acceptance of the human/nature divide. As argued by Crutzen, McNeil et al (Steffen, Crutzen and McNeil 2007), the Anthropocene - which we are led to believe began with the English Industrial Revolution of the eighteenth century - marks the point at which humanity became the greatest threat to the Earth system. This paper takes issue with that general diagnosis, arguing that the Anthropogenic view of the Industrial Revolution is critically, and perhaps fatally flawed. The Anthropogenic argument that humanity is overwhelming the planet leaves out of the analysis the ecological transformations that capitalism has evolved through. Perhaps even more surprising is the fact that the Anthropocene argument does not even attempt to take the capitalist worldsystem, or capitalism itself, to task in the development of ecosystemic destruction over time and space.
} 
Unlike Malthus, David Ricardo did in fact have an understanding of the business world, so much so that he was widely known as a master manipulator of the money market, no doubt as a result of his being the son of a wealthy Dutch banker. Fusfeld refers to Ricardo as "the apostle of capital accumulation" (2001, 41). His view was one that can be characterized as a strict form of economic liberalism, fetishizing the concept of economic growth to a point of near religious fervor. Ricardo was on the side of big business in regard to the raging debate of the day, the debate over England's corn laws. By "corn" was meant wheat and all other grains, which at that time were simply referred to as corn. He argued that, "Artificially high food prices would lead to a misallocation of productive resources into agriculture and out of manufacturing, thereby hindering the nation's natural development of industry" (Ibid: 43). At this time in England especially, it was a dominant belief that only through industrialization could real economic growth be had; the kind of economic growth that provided, ironically in the case of the Malthusian argument, exponential population growth. It was argued that "England's future lay with industrial expansion, not with agriculture, and they demanded outright repeal of the Corn Laws" (Ibid: 42). It was Ricardo's influence that put in stone the central tenet of economic liberalism that prices must be kept low in order for England to sell its goods around the world. Higher prices meant reduced output, and therefore reduced profit margins - consequences are damned.

While Ricardo is regarded by many as a problematic figure because of his dogged support of the business elites, he nevertheless brought about some very important discussions about the role of land cultivation and rent that Marx would later run with, 
challenging Ricardo, but also paying homage in some cases, particularly in regard to his reworking of the Smithian labour theory of value. Both were, after all, members of the classical economics school of thought, though Marx argued for extremely different solutions to the problematics therein. Ricardo defined rent as "that portion of the produce of the earth, which is paid to the landlord for the use of the original and indestructible powers of the soil" (Bowditch and Ramsland 1961: 72). If only the soil was as indestructible as Ricardo believed it was. He argued, "When in the progress of society, land of the second degree (land being cultivated a second time in rotation) of fertility is taken into cultivation, rent immediately commences on what of the first quality, and the amount of that rent will depend on the difference in the quality of these two portions of land" (emphasis added) (Ibid: 73). Further, and perhaps most importantly, "When land of an inferior quality is taken into cultivation, the exchangeable value of raw produce will rise, because more labour is required to produce it" (Ibid). It is indeed difficult to look at the contributions of David Ricardo as anything other than a painfully optimistic, if not utopian, version of the capitalism of Adam Smith, minus the major redeeming fact, for our purposes here, of the Smithian view, that being his well-known belief in the limits to capital accumulation. Smith at least believed that there was a kind of socio-ecological barrier to the continued, unfettered accumulation of wealth that Ricardo simply saw as illogical in the face of the awesome power of the capitalist mode of production (Fusfeld 2002: 39-44). For Ricardo, the market was the all seeing eye of the future that all of society ought to want, and was coming whether they wanted it or not. 
Unfortunately, for the global ecosystem, Ricardo's inclination to believe devoutly in the regenerative capabilities of capitalist production was quite right. Williams puts it this way: "The symbols of democracy, in the English mind, are as likely to be institutions of power and antiquity, such as the Palace of Westminster, as the active process of popular decision, such as a committee or jury. A more decisive social image came from the other part of this movement: the rise of economic individualism" (Williams 2011: 131). Indeed, is not the real goal of 'economic liberalism' a kind of individualization of the human condition? Williams sheds light on this question, asserting, "Earlier forms of individualism were primarily the assertion of rights to do and say certain things - society was judged and reshaped to guarantee the exercise of this positive freedom. Modern individualism in part continues this tendency, but on the whole puts more emphasis on a negative freedom: the right of the individual to be left alone" (Williams 2011: 136); the right of the individual to be left alone to pursue his or her wants, regardless of the effects upon society, with the proverbial 'market' as the arbiter in such affairs of humanity. Again we see the undeniable precursor to today's neoliberalism.

'Modernity', as a concept, took for granted, strategically I might add, the basic reality that with the rise of the Industrial Revolution came the rise of a new kind of capitalism, one that was worldly. And at this new corporate stage, "society was no longer thought of as merely providing a market: the organization of a society itself was essentially a market organization" (Ibid). If this is the case, and I implore anyone to argue otherwise, the Industrial Revolution brought with it a kind of re-imagining of society as collectivized commodity, or modernity as the re-organization of all of human 
and extra-human natures. Where Smith and Malthus both underestimated the ability of the capitalist system to invent ways to surmount the socio-ecological obstacles to continued high-level economic growth, Ricardo was under no such illusion, for he was a deep believer in the power of the capitalist enterprise to surpass any limitations in its continued dominance. However, there was, and still is, a heavy price to be paid for this sycophantic belief in the endless accumulation of capital. The world-ecological viewpoint, highlighted in the later half of this paper, will take on this issue directly.

\section{The Socio-Cultural Revolution}

It is important that we not skip over the more socio-cultural aspects of the Industrial Revolution as well. Where industrialization is a response to socio-ecological transformations in agrarian-urban relations, resulting in the development of the capitalist world-system, modernization is the socio-cultural framework that accompanies this

collective movement. David Apter writes that, "Any material improvements in a community create a demand for more" (Apter 1965: 46). The sociopolitical elements of industrialization are most palpable in the discussion of modernization, a discourse that government - to the degree that there was any form of democratic governance in most of pre-modern English history - supported unapologetically. "Quite often the first modernizers have been those who realized that if they did not change their roles they would be forever barred from political power" (Ibid: 47). Modernism is perhaps the most powerful example of a 'regime of thought' (Foucault) that reifies the capitalist narrative. Then, as today, if government does not do the bidding of those within society who 
possess the means to accumulate capital, it runs the risk of being less effective on the global stage.

Modernization is a moot subject if we do not include the role of government in the making of economic markets. As far back as the Chinese tributary economies of the 1300 s, government in one capacity or another, has been the main engine behind the development of markets, be they import, export, or domestic. In the case of British industrial revolution - commonly argued to be the first, a concept I will take up later there is a key question to be asked, and it is done so clearly and concisely by Hobsbawm: "How did entrepreneurs come to see before them, not the modest if solid expansion of demand which could be filled in the traditional manner, or by a little extension and improvement of the old ways, but the rapid and limitless expansion which required revolution" (Hobsbawm 2011: 19). He argues that there are two essential schools of thought on this matter, and that they both suffer from the same occlusion of the obvious answer. On the one hand, some economic historians argue that it was the domestic market that built the need for an economic revolution, and on the other, it was the foreign, or export market that caused the rise in demand. Neither is correct, for it was always and remains both. The often-neglected third factor, and what I argue ought to be the first factor, is government (Ibid: 20).

Modernization, I argue, came as a result of the geographical expansion of industry and empire, usually in the form of colonization. In fact, one might argue colonization was a dependent requirement for modernization. I must be allowed to digress here slightly, for it is important that our understanding of modernization is placed in the 
framework I will be outlining later. Colonization, or the physical domination of a one society by another society's leaders, was only possible through the development of ships. Countries that had developed the ability to cross the oceans to exploit the resources of other cultures were, by definition, developed, while the exploited cultures were underdeveloped. There was, and remains, a positive relationship between the strength of a country's transterritorial infrastructure and a country's level of economic development. Few statements could be more obvious. International trade between Europe and Asia was already in full swing by the thirteenth century, led first by the Venetians and the then developing Genoese capitalism (Wallerstein 1974), and then the rest of Europe, including Britain. Cippola states, "The make-up of international trade between East and West seems to point to the thirteenth and fourteenth centuries as the period when Europe gained the upper hand. In the twelfth century the West still exported to the East mostly raw materials (iron, timber, pitch) and slaves, and imported manufactured goods and raw materials" (Cipppola 1980: 210). This was a period of global expansion of the European world-economy, symbolically represented by a cargo ship that set sail in the summer of 1338 for the East with none other than a clock, the "symbolic beginning of the export of the machinery reflecting the incipient technological supremacy of the West" (Ibid), he argues. This all points to the basic idea that modernization is but an eighteenth century term to describe industrialization, which again, I argue is as old as man. The same can be said of mechanization, which goes as far back as the discovery of the water-wheel, the pulley system, and so on. The point here is to not get bogged down by the propagandistic modernist discourse, for it is merely a relatively newer term for an aging phenomenon. 
The Industrial Revolution, as it has been discussed here thus far - in the technoeconomic realm - is perhaps better analyzed as the beginning of the modern era, for none of the characteristics of the modern era - modernization, mechanization, industrialization - actually originate even remotely at the time of the eighteenth century. As with all epoch-making or at least era-making transformations of society, there were also, dare I say revolutionary, antecedents that may be messy and unclear at times, but nevertheless are the foundations on which such monstrously gross concepts as industrial revolution rest upon. Was there not a demographic revolution, an agricultural revolution, a 'commercial revolution' (Deane 1965), and a transportation revolution (which was lightly addressed above) that all happened previous to what is commonly referred to as the Industrial Revolution? Or were all of these more minor revolutions just precursors to the big revolution that was modernity? Regardless of where we place modernity in the grand scheme of history, we can safely say that industrialization was a precursor, so it is not of great import to this paper.

What remains unquestionable at this point is that there was indeed a historically important surge in the extractive and exploitative capabilities of the capitalist worldsystem during the eighteenth and nineteenth centuries. This we can surely grant to most narratives of the Industrial Revolution. It seems, among all historical treatments, there is a no agreement on the definitive start, middle, and end - if in fact there is an end - to the phenomenon, unless one only consults liberal economic thinkers. Regardless of the dominance of what I have called the techno-economic interpretation - and it is clearly the dominant narrative today, as it was then - there are many important questions about time, 
space, and nature that have been curiously left out of the debate about the grand collective story of the Industrial Revolution. Landes argues, "The Industrial Revolution and the subsequent marriage of science and technology are the climax of millennia of intellectual advance" (Landes 1969: 555). It is, for Landes, and so many others, not the availability of cheap and indeed free labour; not imperialism and colonization; not 'natural advantages' (Mill 2004: 121-122); not 'accumulation by dispossession' (Harvey 1982, 2003); no, it is a unified, progressive advance of human ingenuity. The ecological surpluses we are afforded as members of the web of nature is taken as a given in the mythology of economic liberalism, a key point we will tackle in the final chapters.

The fetishism of economic growth, above all else, remains uniquely consistent in the techno-economic view of industrialization. It is this particular aspect of the Industrial Revolution of '1750-1850' that is still pointed to today as the classically defining characteristic. It is a mythos that continues to gain more traction by way of the neoliberal movement, which arguably began in the late 1970s; a movement that has added little and reified much about the liberal economic vision. Milton Friedman is the intellectual king of the neoliberal advance, leading a front line that began at the University of Chicago (Peck 2010). One of the most precious arguments of the neoliberal interpretation of the Industrial Revolution is Friedman's suggestion that:

The main source of the agricultural revolution (the most important antecedent to all industrial revolutions, as we will soon find) was private initiative operating in a free market open to all - the shame of slavery only excepted. And the most rapid growth came after slavery was abolished. The millions of immigrants from all over the world were free to work for themselves, as independent farmers or businessmen, or to work for others, at terms mutually agreed (1990: 3-4).

In Friedman's fanciful vision of the commodification of agriculture, slaves were made free to compete upon the wonderfully level playing field of capitalism. Their chains were 
let loose so that they could enjoy the righteousness of 'the market', an activity previously applicable only to White, rich men. As though lush grasses padded the feet the newly freed men, "Industry and agriculture marched hand in hand" (p. 4). The real growth of the Industrial Revolution, for Friedman, came not as a result of the outright theft of human labour and the free gifts of nature, but because of the newly freed men who once were in those chains. This logic does not differ greatly from the logic of relatively sudden, dramatic, unified, and progressive economic growth that is routinely associated with the Industrial Revolution of the classical mold. It is really beyond the scope of this paper, and not entirely necessary, to do a full accounting of the influence of economic liberalism in the development of the narrative of the Industrial Revolution, but once can safely say it is alive and well, and still the dominant narrative. ${ }^{5}$

Whenever one looks critically at dominant regimes of truth - of which the liberal economistic view of the Industrial Revolution certainly qualifies - they run the risk of relying upon hindsight at the expense of relationality with the then existing viewpoints. This is the impetus for the goal of revisionist history. That is, history written from the

\footnotetext{
5 There are many writers, older and more recent, who all succumb to the fetishization of 'economic growth' in their treatments of the Industrial Revolution: Milton Friedman and Rose D. Friedman. 1980. Free to choose: $a$ personal statement. New York: Harcourt Brace Jovanovich; For a view of growth in the Industrial Revolutoon that is less centered on the strange notion of 'economic freedom' one finds with the neoliberal argument, Hartwell does a better job of objectively portraying the realities of growth, though still completely dismissive of the using up of ecological surpluses afforded by nature - Ronald M. Hartwell. 1970. "Improvement Defended," in The Industrial Revolution in Britain; triumph or disaster? by Philip A. M. Taylor, Massachusetts: D. C. Heath and Company; R. M. Hartwell. 1967b. The causes of the Industrial Revolution in England. London: Methuen; Dean's analysis, while completely adherent to the idea that English industrial revolutions are the only ones that truly matter, is nonetheless very useful. She uses a lot of very good data regarding population displacement and labour indicators - Phyllis Deane. 1979. The First Industrial Revolution, 2nd ed. Cambridge, Engl.: Cambridge University Press; Both Landes and Thompson use growth and modernity as their key metrics for the Industrial Revoution, focusing little to not at all upon labour and political institutions in their analyses - David S. Landes. 1998. The Wealth and Poverty of Nations: Why some are so rich and some so poor. New York: Norton; Allan Thompson. 1973. The dynamics of the industrial revolution. New York: St. Martin's Press.
} 
perspective of what we know now - but in light of what was known then. The task undertaken here has been to outline the more established narratives of this rather ominous phenomenon we call the Industrial Revolution. The task going forward will be to revise those narratives, to fill in the gaps of the story and provide context where there appears to be none. We cannot change history, but what we can do is change our understanding of it and to explain it in a way that does not lead directly to the reification of its dominant discourses without critical questioning of their accuracy and causally connected implications. 


\section{CHAPTER TWO: Industrial Revolution over the Longue Durée}

To discuss civilization is to discuss space, land and its contours, climate, vegetation, animal species, and natural and other advantages. It is also to discuss what humanity has made of these basic conditions: agriculture, stock-breeding, food, shelter, clothing, communications, industry, and so on. - Fenand Braudel (1993: 9-10)

In the previous section I intended to engage a brief review of the development of what might be called the dominant narrative of the Industrial Revolution, one entangled within the linearity of the ideology of economic liberalism. In so doing, I also traced the phrase Industrial Revolution back to the French Revolution, but noted that it was indeed Toynbee who has been historically given the credit for its grand entrance onto the stage of world history. Toynbee in fact gave us his definition of the Industrial Revolution in his Lectures on the Industrial Revolution, its 'essence' being "The substitution of competition for the mediaeval regulations which had previously controlled the production and distribution of wealth" (Toynbee 1884: Lecture VIII, pp. 85-93). This neatly packaged view of what is an ineluctably complex phenomenon is what I have opted to identify as the techno-economic narrative of the history of the Industrial Revolution. It is, for all intents and purposes, still by far the most dominant narrative of the Industrial Revolution one is likely to encounter in the fields of political science and economic history - the main arenas in which it is most often discussed.

In order to better understand the present we often have to look deeper into the past. When we do that in this case, we find a much more relational, and very long-term method of looking at this gross concept. Particularly in the realm of political theory where so little has been attended to regarding industrialization - there is a common 
disease of writing and thinking that assumes history progresses in neat little time-boxes of 50-100 years. This adherence to short-form linear history, in no small part, stems from the increasing pressure to ask smaller and smaller questions, for academic research is typically funded by those who want profitable (in more ways than one) answers in the shortest possible time. Ian Shapiro explains, "Acknowledging the relational character politics brings with it a theoretical holism that threatens our jobs in the intellectual division of labour, for it implies a need for substantive interdisciplinary knowledge" (Shapiro 1989). One could very easily replace the word 'politics' in the above quote with 'industrialization', the Industrial Revolution, 'revolution', and so on. Looking at history, not as broken snippets of a much longer story, but as complex assemblages in the larger web of life over space and time, allows us to begin to construct historical narratives that are far more explanatory. As stated by Wallerstein, "The past can only be told as it truly $i s$, not was. For recounting the past is a social act of the present done by men of the present and affecting the social system of the present" (1989: 9). Following this beat, we can say that looking at the temporalities of the various narratives of the Industrial Revolution critically can uncover new ways of seeing ongoing industrialization and capitalism, in both the historical and future tenses. The 'present' thus becomes a kind of melding of the past and foreseeable future.

In his infamous essay History and the Social Sciences: the Longue Durée, French world-historian Fernand Braudel dropped a pin-pulled grenade in the center of the social scientific community as it stood in 1958 , stating,

Nothing is more important, in our opinion, than this living, intimate, infinitely repeated opposition between the instantaneous and the time that flows slowly. Whether we are dealing with the past or the present, an awareness of the plurality of temporalities is 
indispensable to a common methodology of the human sciences" (Lee 2012: 243) (emphasis added).

This article was in fact where Braudel's usage of the term longue durée first appears. Whereas so many historical writers base their temporal frames on intervals of '10, 20, or 50 years', Braudel seeks to see time in what used to be referred to as 'episodic historical time'. "No matter the designations," he argues, "we shall center our discussion on these two poles of time, the instantaneous and the long-term" (Ibid: 244). Not to put too fine a point on the matter, he continues:

Take the word "event" ... by the perhaps contrived game of "causes" and "effects" dear to historians in the past, it can include a period far longer than its own occurrence. Indefinitely stretchable, the event becomes linked, by design or by chance, to a whole chain of events, of underlying realities that then become impossible, it seems, to disentangle, one from the other" (Ibid: 245).

When we employ Braudel's idea of the longue durée we begin to see such magnificent subjects as the Industrial Revolution, and industrialization more generally, in an entirely new light. Further, his critical interpretation of the 'event' is crucial to our eventual world-ecological re-defining of the phenomenon as something more akin to a 'worldecological event', which we will tackle later. The concept of revolution has a long history of being 'infinitely stretchable' in regard to the various temporalities it is examined within. ${ }^{6}$

The writing of history over the very long term is at the core of viewing industrial revolutions as intertwined with much larger systems. More precisely, by viewing the Industrial Revolution in this way, we begin to see the semi-autonomous characteristics of what Wallerstein calls a world-system. In fact, the Industrial Revolution is quite intrinsic to much of the work of Wallerstein and to what has become widely known as world-

\footnotetext{
${ }^{6}$ We need only remind ourselves of the great work of Raymond Williams in The Long Revolution, as well as the numerous writings of Marx and Engels that refer to the great Socialist revolution being a never-ending, always evolving process that has no identifiable beginning and end.
} 
systems analysis. It is utterly important to spend some quality time examining Wallerstein's explanation of the development of the world-systems approach to the analysis of world-historical events, transitions, epochs, or whatever other terms we may want to use.

In the late fifteenth century and early sixteenth century, there came into existence what we may call a European world-economy. It was not an empire yet it was as spacious as a grand empire and shared some features with it. But it was different, and new. It was a kind of social system the world has not really known before and which is the distinctive feature of the modern world-system. It is an economic but not political entity, unlike empires, city-states and nation-states. In fact, it precisely encompasses within its bounds (it is hard to speak of boundaries) empires, city-states, and the emerging "nation-states." It is a "world" system, not because it encompasses the whole world, but because it is larger than any juridically-defined political unit. And it is a "world-economy" because the basic linkage between the parts of the system is economic, although this was reinforced to some extent by cultural links and eventually... by political arrangements and even confederal structures (Wallerstein 2011: 15).

This rather long quote is warranted on two accounts: First, it clearly displays what a 'world-system' is and is not, and second, it opens up the Industrial Revolution to the real discussion of its historical antecedents that were only briefly mentioned in the previous chapter, precisely because the classical view of the Industrial Revolution near totally discounts these antecedents in its development. In short, it allows us to begin looking at the phenomenon as part of a much larger, longer-acting, and still ongoing world-system. When the long form of history is employed there arises much contention in regard to describing the industrial revolutions that came before the Industrial Revolution. It will be argued herein that the Industrial Revolution was a period of great intensification of the extractive and exploitative capabilities of the then already raging capitalist European world-economy that arose with the fizzling out of European feudalism. Wallerstein explains,

It was in the sixteenth century that there came to be a European world-economy based upon the capitalist mode of production. The most curious aspect of this early period is 
that capitalists did not flaunt their colors before the world. The reigning ideology was not that of free enterprise, or even individualism or science or naturalism or nationalism. These would all take until the eighteenth or nineteenth century to mature as world views... The distinctive feature of a capitalist world-economy is that economic decisions are oriented primarily to the arena of the world-economy, while political decisions are oriented primarily to the smaller structures that have legal control, the states (nationstates, city-states, empires) within the world-economy (Wallerstein 2011: 67).

In this sense the Industrial Revolution is clearly a 'take off' of a sort, but not of industrialization or the capitalist world-system (for they were already there), but of the dogmatic subject social construct we refer to as modernity.

The hardheaded focus upon industry as the child of man's conquest over nature via the commingling of science and technology stems directly from central ideations of liberalist economic thought, bordering on capitalist propaganda. Writing about the central conflict of the 'modern age', Robert M. Young argued, "In many ways, we think of our humanity as something different from, as over against, the concept of nature. This 'over-against-ness' is one of the pervasive trends in the Western and intellectual traditions. Humanity, we like to think, is not merely a natural phenomenon. Yet we believe deeply, if we take science seriously, that there is nothing about man which is not, at least in principle, explainable by the concepts and methods of the natural sciences" (see Benthall 1974: 235-74). We must admit, however, that even the 'natural sciences' are at first manifestations of the human imagination and humanity's quest to build explanatory models for what otherwise appears chaotic. Modernity, critically gazed upon, is wholly dependent upon a religion-like belief in natural scientific answers to questions that are primarily socioeconomic, and as I have thus far been laying out, also ecological. Perhaps the worst aspect of this sycophantic trust of 'science' over all else is that the scientizing of society, if you will, turns science into politics ('political science') and politics into 
science. Trent Schroyer, whom Young called a disciple of Habermas, argued, profoundly, that "Contemporary science and technology serve as a new strategy for legitimating power and privilege" (1971: 297-321, esp. p. 297). "Scientism," argued Habermas, "means science's belief in itself: that is, the conviction that we can no longer understand science as one form of possible knowledge, but rather must identify [all] knowledge with science," and that "the scientistic image of science has become, a dominant legitimating system of advanced industrial society" (1968: appendix), or what, in light of this paper thus far, can be called the world-system of capitalism.

Economic growth is, for better or for worse - and I argue for the worse - seated at the center of the vast majority of interpretations of the Industrial Revolution, past and present. However, as was mentioned previously, the economic growth, even of the late eighteenth and nineteenth century, was anything but uniform and progressive, leaving ample room for re-interpretation. Nevertheless, Hartwell, for instance, states that the "essential character" of the Industrial Revolution is "the sustained increase in the rate of growth of total and per capita output at a rate which was revolutionary compared with what went before" (Hartwell 1967a: 8) (emphasis added). 'Revolutionary' in this sense clearly seems to mean drastically different from what came before. Otherwise, the use of the word is incorrect, for the 'sustained increase in the rate of growth' was over a very long, slow curve, stretching over more than one hundred years. Further, the growth that Hartwell suggests is only historically evident in Europe and America at that time, and it is scarcely unified and progressive, especially previous to the twentieth century. So not only does that view limit the geographical scope of the phenomenon drastically, but it 
also assumes a England-centric vision of history, negating the previous two-centuries of boom and bust all over the rest of the continent, as well as some areas of South America and North Africa (Moore 2003a, 2003b, 2002a, 2010a, 2010b; Braudel 1972a, 1972b, 1973, 1982; et al.). Holland, for example (though it is often in contention whether or not Holland was really a nation-state with the relative autonomy of the Dutch Republic), was certainly more 'modern' than England was during most of the long seventeenth century, which we might logically nail down as $1550-1750$. 'Economic specialization', a certain requirement for increasing the rate of economic growth from a liberal capitalist standpoint, ${ }^{7}$ was already, previous to the industrial revolutions of England, very advanced in the realm of industry and agriculture. Holland, according to Wrigley, "was the common carrier of Europe."

Her cities were numerous and prosperous, and the percentage of the population living in towns was higher than in England and far higher than in most other countries ... Capitalism was perhaps less impeded by legal and institutional handicaps than anywhere else. Real wages were the highest in Europe throughout the later sixteenth and seventeenth centuries, and for much of the eighteenth century also. And yet there was no early industrial revolution in Holland: indeed it was unusually late in making an appearance there (1988: 103).

The above quote brings two contradictions of the classical view of the Industrial Revolution to the forefront: First, it documents that the phenomenon was anything but a purely English one. Second, it shows that industrialization does not require an increase in the rate of economic growth (Deane 1979), as much as it requires an increase in the efficiency of food production to feed the industrial labour pool.

There was an array of industrial revolutions - or large advancements in the machinery of production - between the eleventh and fifteenth centuries that all failed to

\footnotetext{
${ }^{7}$ Here I am thinking of Smith and Ricardo, and of course the modern neoliberal economistic thinkers, such as Hayek, Stigler, and Friedman who came much later, but nonetheless expanded upon Heyek and Stigler's reactionary anti-socialist econometrics.
} 
bring about the economic boom that the Industrial Revolution is so famous for. Braudel has written at length on the conundrum, for example, of the 'mill revolution' of the twelfth and thirteenth centuries, namely that of why "the exceptional conditions which were combined in fifteenth-century Milan (including 'a whole range of mechanical devices which would actually be developed during the next four hundred years, including electricity, most of which developed by or influenced by the work of Leonardo da Vinci) failed to create any such need or demand" (emphasis added) (Braudel 2011: 550) for further industrial revolution. Why did it not go on and thrive the way the English revolution did? In typical fashion for Braudel, a wonderfully disobedient thinker, he follows this question with another set of questions, all of which have yet to be adequately answered, or even followed up on by most of the rest of the historical writing since his death, making his work all the more important to the present period:

Was it not [rather] Milan's misfortune to be so close to Venice, yet so far from sharing Venice's dominant position? And not to be a port, with access to the Mediterranean and the international export trade, free to experiment and take risks? Is the failure of Milan's 'industrial revolution' perhaps proof that an industrial revolution, as a total phenomenon, cannot be built up entirely from within, simply by the harmonious development of the various sectors for the economy; that it must also be based on command of external markets - the sin qua non of success? (2011: 552)

What Braudel brings brilliantly into the picture is that of the need for 'external markets' to the advancement of any industrial revolution past the social and ecological boundaries of a given territory. This is one major difference, if not the major difference between the Industrial Revolution and industrial revolution more generally.

One affect, if you will, of engaging the Industrial Revolution over the longue durée is that we are forced to see space-making and life-making activities over time as much more slowly evolving than most of us would like to believe. By looking at history 
in slow motion, we begin to see the socio-ecological transformations that have driven most of the age-making demographic, economic, and technical revolutions that led up to the subjective human construct we call 'modernity'. Bruadel's discussion of daily life in history is quite explanatory here. He called "everyday life" the "shadowy zone ... lying underneath the market economy: this is that elementary basic activity which went on everywhere and the volume of which is truly fantastic," arguing that "[This is the zone in which] the difficult assembling of a number of parahistoric languages take place demography, food, costume, lodging, technology, money, towns;" the basic material structures of life that establish a "limit, a ceiling which restricts all human life ... [which] separates the possible from the impossible" (Braudel 1981: 23, 27). As explained by Moore, "Braudel believed that historical analysis should begin not with the rapidity of social change, but with the slowest moving processes" (Moore 1997). However inconvenient this kind of historical narrative is to current scholarship, what it does allow us to do is critically re-examine the techno-economic and otherwise liberal narratives of industrialization inclusive of the 'socio-ecological transformations' (Moore 2007, 2008, $2009,2010 \mathrm{a} / \mathrm{b} / \mathrm{c} / \mathrm{d}$ ) that have always inspired geographical expansions of the 'capital frontier' (Arrighi 1994, 2008), as far back as one is willing to travel.

Geographical expansion, usually through means of state-directed actions, are always at once ecological and social, an historical realism that Smithian logic, "with rising demand driving the geographical expansion of a reified 'Europe'," (Moore 2010a) was conspicuously incapable of incorporating into its narrow economistic narrative. "Ecological contradictions mobilized by the expansion of commodity production and 
exchange," argues Moore, "implied and indeed necessitated regional ecological crises. These were resolved, recurrently, through renewed geographical expansion" (Ibid). Resource frontier expansion is as old as humanity itself; a means of overcoming regional ecological crises often resulting from small increases in population and corresponding to dominant agricultural regimes (Hughes 2001; Elvin 2003). History over the longue durée allows us to see these geographical expansions in a way that linear economistic history does not, holistically. Where agrarian histories written from agrarian viewpoints leave out much of the sociopolitical implications and impetuses of food regimes, Braudel's historical methodology and Moore's world-ecology synthesis - which we will engage deeply in the next chapter - brings to the forefront of the discussion of industrialism, modernity, and power, the always and forever expanding commodity and resource frontiers (Moore 2002a, 2010a, 2010b), frontiers that far preceded the capitalist worldsystem, but nevertheless frontiers that the system evolved through.

\section{The fall of Feudalism and its Crises}

With the fall of feudalism in Europe, a new and vastly different economic organizational apparatus began to develop. Feudalism was not 'pre-capitalism' or 'proto-capitalism' as is sometimes argued, it was indeed 'real capitalism' (Moore 2002a). It can much more accurately be viewed as a "series of tiny economic nodules whose population and productivity were slowly increasing, and in which the legal mechanisms ensured that the bulk of the surplus went to the landlords who had noble status and control of the juridical 
machinery" (Wallerstein 2011: 18). The surplus was only useful to the lords if it could be sold, so unsurprisingly, towns began to spring up around the need for artisans and other makers of various products to sell their goods to very small minority of people who could afford to buy them. Out of this small group grew a kind of merchant class made up of representatives of the lords, charged with selling off the surpluses of their indentured peasants, and another group made up of those peasants who managed to hold enough of their production beyond payments to the lords to sell it on what was essentially a localized market system (Wallerstein 2011; Marx 1967b, 1973, 1978d; Moore 2002a). According to Daniel Thorner, "We are sure to deceive ourselves if we think of peasant economies as oriented exclusively towards their own subsistence and term "capitalist" any orientation towards the "market." It is more reasonable to start by assuming that, for many centuries, peasant economies have had both (a market economy in the towns and a subsistence economy in the peasant communities) orientations" (parenthetical emphasis added) (Thorner 1964: 422). Marx identified this new development as an 'irreparable rift in the metabolism between town and country', a concept we will engage momentarily. While trade was, contrary to popular belief, quite important during even the most intensive periods of the feudal era, it was rather limited, and this led to many problems that the relatively atomized feudal estates were incapable ultimately of handling. Most critical was the falling rate of raw inputs against a growing urban population.

There are other interpretations of feudalism that must be understood here as well, for feudalism will play a major part in the development of the next chapter. Lefebvre saw it as "the hierarchical relationship between a lord and his vassals" (1976: 122), an 
obviously parsimonious definition at best. Similarly, Kaye argues, the history of that time "was not just written from the perspective of the top but was also limited to studies of the top" (Kaye 1984: 73). Marc Bloch (1961) and Rodney Hamilton (1949, 1973, 1985) were both world-historians who challenged this rather narrow view of feudalism. While they acknowledged that "feudal Europe was not all feudalized in the same degree or according to the same rhythm and, above all, that it was nowhere feudalized completely" (Bloch 1961: 445), they attempted to broaden the conception such that the "principle feature was the domination of the rest of society, mainly peasants, by a military landowning aristocracy" (Hilton 1976: 30). Moore notes, "This broader conception of feudalism has strongly influenced the world-historical perspective since the 1970s," but "one major exception to this generalization is Giovanni Arrighi" (Moore 2002a). He argues that while feudal relations are

no doubt relevant to an understanding of English, French, Polish, Swedish and many other "national" histories of the European world, they nonetheless are largely if not entirely irrelevant to an understanding of the origins of world capitalism for the simple reason that world capitalism did not originate with the economic activities and social relations [of territorial Europe]. Rather, [capitalism] originated in the interstices [the city-states] that connected those territorial organizations to one another (Arrighi 1998: 126).

Even though Arrighi's understanding of feudalism is more limited than some others, in fact more similar to the earlier simplifications, this was historically strategic and I argue brilliant, for he was attempting to "exclude urban centers in order to designate them prime movers in the transition to capitalism" (Moore 2002a); brilliant because it highlights the economic discrepancies between town and country. Capitalism was built by towns that were built upon the backs of the people of the country. Of this there cannot be much in the way of dispute. However, Moore takes issue with Arrighi on this front, 
asserting "this line of argument tends to reproduce a sterile dualism, pitting the capitalist city against the feudal natural economy" (Ibid). The base point that Moore is asserting here is that "if the broader conception of feudalism is deployed, city and countryside, market and production, are viewed not in isolation but rather dialectically" (Ibid). This is a worthy argument, for Arrighi avoids engaging the dialectic on multiple fronts in most of his work, leading to a kind of strict history that leaves little room for nuance. And supporting that idea, Dale Tomich sees production and exchange as "points of departure" for the examination of large-scale "social economies" (Tomich 1997: 299). On the other hand, by separating out the feudal towns from the rural countryside, as Arrighi did, we can arguably engage the dialectic in a geospacial analysis of the development of feudalstage capitalism.

Situating the "struggle for feudal rent" (Hilton 1976b) as the center of the feudal crisis allows us to begin to look at the socio-ecological implications of the eventual fall of feudalism, or what Moore calls "feudalism's long march toward ecological crisis" (Moore 2002a). That was a march that began with three hundred years of "rapid population growth, leading to new settlement throughout central and eastern Europe" (Ibid), the precursor to the eventual growth of the capitalist world-economy. The feudal worldeconomy was limited geographically in regard to trade. The merchants of the day primarily traded locally, with a small group of long-distance traders opening up new routes, but they traded still mostly in luxury goods meant for the landed classes. 'Bulk trade' (raw materials) was only possible "with the expansion of production within the framework of the modern world-economy" (Wallerstein 2011: 20), which would not 
come for some time. Essentially, trade was limited to merchants who thrived not necessarily on high profits, but upon "those who could extend favor and protection," according to Lattimore (1955: 124-125). It is this limited trade organization that began to erode the foundations of the feudal economy in Europe, leading to what Moore and others call 'the crisis of feudalism'. However, there is much disagreement on what exactly makes up the crisis - if it was ecological, political, or economic. I argue, in concert with Moore and Wallerstein, that it was all of the above.

It is important to note that while feudalism fell rather quickly, trade was actually expanding as the feudal order began to grind down to a halt. Towns began to be formed and populations began to grow and migrate toward those towns. The more this spacemaking continued, the more the feudal system began to fall. At the same time, other associations were in the making, associations that would ultimately become guilds, or relatively autonomous associations among workers, artisans, and other craftsman. Along with these new associative structures came what Cipolla asserts was an "urban revolution" (Cipolla 1994: 79), followed by the development of the commune, which he identifies as, at that time, "nothing more than the sworn association of citizens" (Ibid). An interesting difference between how Cipolla writes about the rural-urban divide and how Braudel and Wallerstein approached the issue is found in how he writes about the marked differences between 'towns' and 'cities'. "Towns had existed in ancient Egypt, as in the classical world of Greece and Rome. In the Middle Ages, towns existed in China as well as in the Byzantine Empire. But the cities of medieval and Renaissance Europe were quite different from the towns of other areas and times" (Cipolla 1994: 120). In the 
Byzantine Empire "merchants, professionals, and craftsmen" were not elevated to any kind of social prominence, as was the case with the rise of the towns in England. While towns had existed throughout much of human history, towns as unique centers of differentiated social organization and status did not arise until eleventh to thirteenth century, precisely during the height of feudalism. The towns people developed in this time a separateness, exemplified not only by the classic moats and gates that separated towns from rural villages, but they "evolved their own culture and their own values... The emergence of European towns... was not a spin-off of regional evolution. It was rather the expression of a cultural and social revolution which was based in the towns" (Cipolla 1994: 120). In other words, there was not a unified change in the way society was organized, either from the towns out to the rurals or from the rurals to the towns. On the contrary, this was very much a development of the indignation of the 'feudal establishment' toward outsiders.

The rural-urban divide, often written as an affect of the Industrial Revolution, is clearly, like industrialization itself, a long-term development. Towns, as far back as the early feudal period, were, to the people of Europe from the eleventh to the thirteenth centuries what America was to Europeans in the nineteenth century. The town was the "frontier," a new and dynamic world where they would find opportunities for economic and social advancement, and where there would be ample reward for initiative, daring, and hard work. "Stadtluft machts frei" (town air makes one free) it was said in German" (Ibid: 119). What Cipolla is bringing to light is that the rural-urban divide is by far not a creation of the Industrial Revolution, but a social revolution that took place over many 
hundreds of years. And this aligns with Marx's concept of social metabolism, in which he examines the problems that arise as a result of the obvious rifts between production in the rural areas and in the urban. Cipolla gives us the precursory story to the Marxian analysis of post-feudal society and its bourgeoning capitalist world-system, and the socioecological crises that would soon come.

Silver Mining: a signaling of the development of early capitalism

Spanish silver mining in the sixteenth century stands a great example of how the capitalist system utilizes the 'spatial fix' of geographic expansion of resource and capital frontiers in order to transcend ecological boundaries to economic growth (Moore 2010a). By the mid-sixteenth century, Europe's great silver and otherwise mining frontiers of Saxon and Bohemia had already begun to break down in dramatic fashion, hastened by the rise of the Potosi, a very high up mountain city in the Andes. The massive 'discovery' of Cerro Rico - one of the most prolific mines in history, one that still produces silver today - was a 'discovery' only in the modern sense of useful finds in the search for the continued appropriation of natures 'free gifts' (Marx 1967, III: 745). The mining of the Andean mountains in during the long sixteenth century created some of the most serious rifts in the metabolism between town and country. The process of silver mining itself actually created these rifts, for the miners lived in town centers, while the labourers lived in what amounts to squalor. More bluntly, the conquerors of the Andes, coming in the form for Spanish mining merchants, lived in the city of Potosi, while the conquered were left to fend for themselves in the countryside. In short, the miners were an 'occupying 
force' the Andeans had rarely dealt with, for the British model of colonization was a gradual occupational one, while the Spanish model was one of sudden impact (Portes 1977, 61; Mumford 2004). In short, it is important to remember that in the process of geographical expansion of the both the commodity and resource frontiers (Moore 2010a) metabolic rifts between town and country are not only created, but virtually cemented in the local cultures of those occupied territories.

Marx, as told by Moore, argued that the "'diaspora of silver' had an epochal role as a 'highly energetic solvent' of seigneurial and peasant forms of production" (2010a). Just as 'Spanish Peru after 1545' was remade in Castile's imperial image, Portes was just the next stop on the long train of resource and capital expansion. It was indeed the beginning of the virtually self-replicating system of supposedly endless accumulation that the capitalist ideology would later treat as an unquestionable regime of truth. More directly, the entire mining frontier - which continues on today - is the prime example of ever-increasing rifts between town and country that arguably started in Latin America, but have continuously expanded out in rhizomatic fashion 'at the scale of the worldeconomy' (Moore 2010a). One could easily take the country/town divide and extend that to the global divide between the then New World and the presumably Old World. "The New World accounted for 74 per cent of the world's silver production in the sixteenth century" (Barrett 1990, 225), and Potosí's project was seven times larger than Zacatas, one of the largest mines in Mexico (Brading and Cross 1972, 571; Garner 1988, 911). Furthermore, there was a massive influx of Indian labourers in the early sixteenth century, who specialized in a style of smelting that used small 'wind-ovens' that worked 
well in high altitude areas, that the Spaniards were able to pay the relatively high transactions costs with the pure silver they accumulated through their domination of the coca leaf trade (Cobb 1947, 117-99; Cole 1985, 3-4). This, however, ultimately lead to a completely untenable labour arrangement in Potosí, in which by 1561, there was a 94 per cent drop in Indian employment in the area, with only 300 labourers working the mines, while the Indian population of Potosí was 20,000 (Cole 1985, 4).

The important point here is that the silver commodity frontier devoured human bodies through labour exploitation as much, and arguably faster and more efficiently, as it did the physical landscape upon which the mining was exercised (Moore 2010a). An anonymous figure in 1603, as cited by Moore (2010a), gives a story that is not unfamiliar to anyone who has visited the mountains of Appalachia:

Even though today, because of all the work done on the mountain, there is no sign that it ever had a forest, when it was discovered it was fully covered with trees they call quinoa, whose wood they used to build the first houses of this settlement ... On this mountain, there was also a great amount of hunting of vicuñas, guanacos and viscachas, animals very similar to the rabbits of Spain in their fur and meat, but with a long tail. There were also deer, and today not even weeks grow on the mountain, not even in the most fertile soils where trees could have grown. This is the most frightening, because now the mountain is covered with loose gravel, with little or no fertile land, crossed with sterile mineralized outcroppings (emphasis added).

It is with only the most minor stretch that we can suddenly see in bright lights the fact that socio-ecological crises are the very heart of commodity and resource frontier expansions. Nature's 'free gifts' are the most costly attributes of early capitalism. It is only through the systemic expropriation of human and extra-human natures that capitalism is allowed to progress in its speed and depth of extractive capability, which I have herein argued is at the heart of the Industrial Revolution. In this view we could easily call the Industrial Revolution a world-ecological event. And it also must be 
pointed out that human nature was the first nature to be forcibly extracted by the initial urge for capital accumulation, accumulation that was first based on the pursuit of power (Moore 2002a, 2002b, 2010a, 2010b). We are witnessing much of the same kind of appropriation by dispossession (Harvey 2003) rampant in the early silver frontiers of Latin America in West Virginia and Kentucky today, where rural coal mining towns have been completely decimated by the mountaintop removal process, leaving nothing but undrinkable water and miles wide cesspools where lush green forested mountainsides used to lie (Marley and Fox 2014). These zones of capitalist waste are growing rapidly in both core and periphery landscapes.

In the preceding sections I have attempted to outline two distinct approaches to writing the history of industrial revolution, one focused upon the shortest possible time spans (the 'classical' or two-century approach, which I have referred to as the technoeconomic viewpoint) and the other upon the longest (the longue durée). The former lends itself to viewing the Industrial Revolution as a unified, progressive phenomenon that took place over two centuries beginning in 1750, coinciding with the rise of coal use in England and Watt's invention of the steam engine. Further, it negates, by necessity, many of the antecedent industrial revolutions that made massive fossil boom of the late seventeenth and eighteenth centuries possible. The latter, on the other hand, is naturally geared toward viewing the Industrial Revolution as a constituent phase - though a very important and powerful one - of a much longer, disunited, not always linearly progressive, systemic series of booms and busts that began roughly with the fall of feudalism in Europe. And crucially, that cycle is still raging on today, only we can 
scarcely understand it without this very long-term historical examination, as inconvenient as it is in our quest.

I have suggested that the Industrial Revolution might more accurately be looked at as a great intensification of the extractive and exploitative capabilities of the then already raging capitalist European world-economy. However, we cannot yet settle on a re-defining of the Industrial Revolution because there is still the question: if not the Industrial Revolution, then what? The critical world-historical approach of Braudel, the world-systems approach of Wallerstein and Arrighi, and the more linear economistic approaches of Wrigley, Landes, Cipolla, among others, all bring together one key presupposition: that we cannot analyze a gross concept like the Industrial Revolution in a way that holds sufficient explanatory power without also engaging history over the longue durée. However, particularly in the case of Arrighi, and of course the linear techno-economic analyses, ecological analyses have been curiously absent. This is not a general critique as much as a factual statement, for the people whom were existing in the time of the coming of the Industrial Revolution, as well as the antecedent industrializations that spawned it, could not have known with any certainty what was headed their way. In other words, we cannot blame the great writers of world-history for not including a parallel history of socio-ecological transformations any more than we can blame seventeenth and eighteenth century human societies for not being more cognitive of ecological limits to growth. Braudel, Wallerstein, and Arrighi were attempting to critically interpret history over the very long term, while also attempting to incorporate the vital additions of Karl Marx and Friedrich Engels, something that was not done well 
before them. Their intellectual battle was laid before them by the apparent addiction to short time spans and area specificity in historical writing, as well as a general lack of socio-economic analysis of mainstream linear historicities. Needless as it may be to say, they had a full plate.

The people of the times these writers expound upon could only scarcely have any idea of what was coming their way. Polanyi explains this conundrum well in regard to the end of the Speenhamland policy of England (what we would today call a welfare state, or perhaps a social democratic state) and the beginning of the Poor Laws following the repeal in 1795 of the Act of 1662:

But the generation of Speenhamland was unconscious of what was on its way. On the eve of the greatest industrial revolution in history, no signs and portents were forthcoming. Capitalism arrived unannounced. No one had forecast the development of a machine industry; it came as a complete surprise. For some time England had been actually expecting a permanent recession of foreign trade when the dam burst, and the old world was swept away in one indomitable surge toward a planetary economy... However, not until the 1850s could anybody have said so with assurance (Polanyi 2001: 93).

In his typically colorful language that sometimes runs the risk of being a little overly theatrical, Polanyi nonetheless uncovers that basic reality that we all have to deal with when writing history, namely that we cannot simply argue that 'if they would have just done this or that' we would not be where we are today. "In the retrospect it may seem as if they had not only attempted to the impossible but had done so by means the inner contradictions of which should have been apparent to them," argued Polanyi (2001: 93). While the hindsight argument is never of much utility, what can be done is a constant reproblematization of the complexities of history over the long run, eventually allowing us to 'write the history of the present', to steal a phrase from Michel Foucault (1977). 
The end of the Speenhamlen regime opened the door to a 'great leap forward' of the capitalist world-economy. "Parish serfdom was abolished, and the physical mobility of the labourer was restored. A labour market could now be established on a national scale" (Ibid: 92). Previous to this massive change in the organization of labour in both the rural and urban spaces, labour was organized in a top-down fashion. There was no choice in profession, as jobs were assigned according to the Poor Law authority, which "managed to keep the social fabric of village life unbroken and undamaged" (Ibid). Speenhamlen was essentially a welfare state that mandated a basic standard of living through the use of 'grants in aid of wages' (supplements to a worker's basic wage that brought them closer to subsistence), 'family allowances', and 'outdoor relief', which kept families from having to enter the workhouse against their own will. According to Polanyi, "This was a return to the regulationism and paternalism with a vengeance just as, it would seem, the steam engine was clamoring for freedom and the machines were crying out for human hands" (Ibid). In other words, the coming Industrial Revolution was in need of what Engels called the 'industrial reserve army' (Engels 1975) of the unemployed. It took an agricultural revolution, or an ecological regime change, to reproduce the primary commodities necessary to feed and house the industrial army of workers necessary to engage the new economic organization that was afoot. And it is with this agricultural revolution that enters ecology into the picture. There must be a synthesis of the linear and relational forms of economic, world, and environmental history if we are to begin to understand the complex interrelations of agro-ecological 
transformations and industrializations over the very long term, and it is this ecological revisionism ${ }^{8}$ that will take us there.

In the following chapter, I will attempt to introduce the reader to a developing paradigm-shifting framework called the world-ecology synthesis. It is an exceedingly complex, but nevertheless 'living theory' in that it is still in its early stages and is relatively non-paradigmatic, or as Wallerstein likes to say 'undisciplinary' in how it tackles the various problems of historical capitalism and world-history generally. It may be viewed as a framework for analysis that is prepared to explain the inevitable arrival of a major paradigmatic shift in the social sciences, to ecologism. The following two chapters of this paper are meant to outline how the world-ecology synthesis can possibly fill in the gaps in the narrative of the Industrial Revolution as it has so far been told, leading us closer to the ultimate goal of this work, which is a critical re-definition that can stand the test of time, and of continuous scrutiny, as any subject like this should.

\footnotetext{
${ }^{8} \mathrm{I}$ am not sure of the use of this term by others, but I intend it to mean precisely what it says, namely, that of revising history in light of new ecological knowledge. I have referred to this in other work as 'ecopolitical reality'.
} 


\section{CHAPTER THREE: Synthesizing the Vertical and the Horizontal}

The ways that we (most of us Americans?) think about or imagine nature have their roots in the origin of capitalism itself. to understand our conceptions of nature we need to understand how capitalism came into being.

- James O'Connor (1988)

The agro-ecological transformations of the long 16th century signaled not only the rise of a capitalist world-economy but equally the emergence of a capitalist world-ecology. What I am suggesting is not the interaction of world-economy in one box and a world-ecology in the other but rather a conception of capitalism in which economy and ecology are increasingly unthinkable without each other. - Jason W. Moore (2003b)

The Industrial Revolution, and the capitalist world-system to be sure, are only possible with a combination of 'vertical' (down into the earth) and 'horizontal' (out across the earth) expansions of the resource, commodity, capital, and labour frontiers (Moore 2010c). The quests for cheap land, labour, and capital form many of the paths of expansion throughout human history, but only after the fall European feudalism do we begin to see the capitalist dynamic centralize itself within the ongoing process of historical industrialization. In most every era, age, epoch, or other episodic temporality in world-history, there exists a push and pull between the resources necessary for the subsistence of society and the rate of regeneration of the ecosystems that provide them in the first place. The classical economists all dealt with this problem in one way or another, but because nature has more or less always been considered throughout modernity and arguably postmodernity, a bounty for man to consume at will, none went far enough. ${ }^{9}$ In other words, I am arguing that humans are given an ecological surplus,

\footnotetext{
${ }^{9}$ It should be pointed out, as it will in later sections of this paper, that Marx and Engels, and Polanyi much later, did go much further on this front than any other of the classical economists. Mill added much here too, but it is a bit beyond the scope of this paper to get deeply into the utilitarian argument, which in the end is still
} 
and as the methods of extraction become increasingly 'efficient', they also become increasingly destructive. Confrontations between the needs of humans and the needs of the rest of nature then begin to create what Wallerstein refers to as 'socio-physical conjunctures' (1974: 35), or what Moore calls 'socio-ecological transformations' (2002a/b, 2003a/b, 2010c, 2013a/b/c, 2014a/b) over space and time, brought about by agricultural regime changes and ecolological crises. The vertical and the horizontal must be discursively synthesized if we are to better understand this still growing phenomenon of capital frontier expansion. In the classical and neoclassical approaches to economic history, particularly in regard to its connection to environmental history, there has been strong attention paid to the economic benefits or costs of vertical expansion (coal, precious metals, natural gas), but comparatively very little attention paid to the horizontal expansions of not only the resource and raw material frontiers, but the labour frontier (slavery).

Examples of the challenges these socio-physical conjunctures create abound throughout human history. In the early eighteenth century, England, for example, was the wheat capital of the world, and the breadbasket of Europe. However, as O'Brien reminds us, food prices in the late eighteenth century began to rise dramatically, "by 200 per cent", which was many times faster than the then current industrial price index (1985: 776). Moore offers a cohesive argument about how England went about facing the dangers of rising food prices and increasing labour productivity involving both 'vertical' and 'horizontal' fixes.

based primarily on an input/output kind of analysis in regard to the human-nature relationship, with humanity still held far above nature. 
Land productivity could have been increased, given the best practices of the period, but only through labour-intensification, and this would have contracted the reserve army of labour, at precisely the moment when it was most needed for industry and empire. The solution was ultimately found in two great frontiers, which yielded two great sources of windfall profit. The first frontier was vertical, moving into the Earth to extract coal. The second was horizontal, moving across the Earth to produce wheat, especially in North America. When another 'great depression' arrived in the 1870s, the era's rapid industrialization was possible on the basis of cheap food, delivered by the co-operative labours of both frontiers, at the same time as mass starvation in South Asia and China and genocide in North America (Moore 2010c).

This crucial period came during the early English industrial revolution, coinciding with the relative exhaustion of the agricultural revolution that took place between 1763 and 1815, a revolution that saw massive enclosures of communal agrarian land that was repurposed for agro-economic growth of potato and maize, the chosen food of the industrialists. The result was not only larger agro-unemployment, leading to essentially forced employment in town centres, but devastation of the health of the soil. It was actually a period of agricultural 'deceleration' - bringing with it lower overall labour productivity, rising cereal prices (now the main source of sustenance for the working class), and increasingly polarized classes of workers and owners (Slicher van Bath 1963; Abel 1980; Jackson 1985). This was, in Moore's terms, "the signal crisis of one ecological regime, and it threatened the rise of industrial capitalism (hence Ricardo's fear that rising food prices world throttle industrialization)" (Moore 2010c). One of the limited ways of England digging itself out of this hole was actually to dig deeper, finding coal, and spread out wider, finding wheat and all sorts of other commodities from the Americas, as highlighted in the above quote. Not to put too fine a point on the notion of 'vertical' expansion of the raw materials frontier, Moore argues:

The ecological surplus is... delivered through some combination of capitalized production (e.g. farm mechanization) and the appropriation of nature as 'free gift'. Energy-intensive agriculture, for instance, develops by appropriating biophysical natures formed over long 
geological time (water and oil pumped from aquifers and fields). In this way, intensive capitalization and extensive appropriation form a dialectical unity (Moore 2010c).

As the title of this paper alludes to, in order to more fully understand the industrializations that preceded the Industrial Revolution, we must find a way to synthesize, or dialectically unify, both the vertical and the horizontal forms of frontier expansion. Otherwise, we are destined for incompleteness in our analysis. This synthesization forms a kind of ecological futurism that I argue is necessary if we are to eventually answer to the socio-physical conjunctures of the present era.

Jason W. Moore minces no words when suggesting that the world-ecology synthesis is an attempt at a 'paradigm shifting methodology'10, in that it is moving toward what may be argued as the logical next step in the analysis of historical capitalism over the longue durée. I argue that it is less a methodology than a framework for the analysis of 'humanity in nature', analysis that takes ecology as its starting point, for the ecological is the impending paradigm shift that Moore's and other's theoretical ruminations are attempting to build an analytical language for. That next step is to bring into dialectical unity 'the accumulation of capital, the pursuit of power, and the production of nature', seeing them not as discrete areas of analysis, but "differentiated moments within the singularity of historical capitalism" (Moore 2011a). In short, it is a paradigm shift away from the less nuanced Marxist views of the division of labour, if you will, into a more cohesive 'synthesis' of the ineluctably intertwined chaos of 'humanity' and 'nature', making it possible to cross the Cartesian line between the two. While it is well-

\footnotetext{
${ }^{10}$ This information was gleaned from conversation with Jason W. Moore during a visit to Binghamton University where he teaches in the Department of Sociology. It can rightly be argued however that it is not really a methodology as much as a paradigm shift to the ecological where there was previously little to no ecologically-motivated analysis involved.
} 
known by many, and highlighted in this paper, that the Marxian canon - particularly the earlier pieces - does in fact take a more unified position in regard to the human-nature relationship, there is at times a kind of fogginess to that distinction. Marx's views on nature can very easily be misinterpreted, and often is by would-be Marxists, as one in which humanity is not inherently intertwined with the rest of nature, but acting upon nature. By taking the step of declaring one's ontological position to be 'post-Cartesianist', one can counteract the common misconceptions of ecological Marxism. It is, in that sense, that the world-ecology framework is, beyond all else, a post-Cartesian one, for it is analysis of historical capitalism as though humans are members of the global ecosystem, as opposed to its controllers and beneficiaries. By making this jump, we remain deeply rooted to the Marxist tradition, but we are freed from the constraints of the more parochial iterations of historical materialism, and its perceived determinism.

The Marxian canon is of taproot importance to this project, as well as to the world-ecology viewpoint, but like all frameworks of analysis, it cannot be expected to contribute to the explanation of every construct of the human mind. It can, however, offer some explanatory notes to many of humanity's most dominant pressures. It is descriptive to remind ourselves of Hegel's most basic contribution to Marx and beyond, namely that all ideas evolve through history by way of a remarkably simple formula: thesis - antithesis - synthesis. ${ }^{11}$ In this sense, we can clearly see, both from what has been

\footnotetext{
${ }^{11}$ While the 'triad' of thesis - antithesis- synthesis actually originates with Fichte, it was Hegel who centered his whole theoretical approach upon it. Where Hegel thought there was a final state to the debate (the synthesis) and indeed 'the end of history', Marx and others who developed it into dialectical materialism argued for a much less deterministic treatment of the idea. Marx in fact argued in the Grundrisse that there could be yet another step, which is the 'negation of the negation'. This simply meant that where the 'synthesis' negates the non-workable pieces of the dyad thesis/antithesis, the next stage would be to negate the synthesis itself, implying a never ending historical progression.
} 
covered thus far, and from a little forethought, that in regard to the Industrial Revolution Smith, Malthus, and Ricardo represent the 'thesis'; Marx and Engels represent the 'antithesis', with Braudel, Wallerstein, Arrighi, and perhaps Harvey extending it greatly; and I shall dare to argue that Moore represents the early arrival of the long-overdue 'synthesis'. Where Braudel takes Marx's 'town-country' antagonism to a whole new level, combining a "sophisticated, multilayered treatment of historical time with a dynamic conception of town and country on multiple geographical scales" (Moore 2003b), Wallerstein takes Marx's critique of capitalism all the way to the world-system formulation - accomplishing what many say was on Marx's writing docket at the time of his death, while still translating the incomparable agro-ecological work of Braudel into more directly politico-economic terms. The world-ecology framework is a knowledge movement geared toward bridging the mythical divide between society and nature, through the theory of capitalism as world-ecology. To see how, and why this must be done, we have to look at three closely intertwined concepts: accumulation, agricultural revolution, and socio-ecological crisis.

\section{On Accumulation}

Marx's 'general law of accumulation' argues that ' the rate of profit is inversely proportional to the value of raw materials' (1967: 111). The reader may want to say that a few times before moving on. The value a society places upon raw materials - the stuff of energy creation, and hence the original source of all capital - must drop in order for capital to accumulate. Moore identifies this as Marx's 'theory of underproduction crisis' 
(Moore 2010), and it brings to light the fact that so many readers and indeed adherents to the Marxian cannon fail to realize that he did not only offer a theory of 'overproduction' to which we are all keenly aware of in the form of 'surplus capital', but that he also offered a theory of 'underproduction'. All throughout Volume III of Capital, Marx eludes to a problematic push and pull between the 'overproduction of machinery', and the 'underproduction' of raw materials (Marx 1967, 119). Applying this to the Industrial Revolution, Moore asserts, "The achievement of the Industrial Revolution was to reverse the greatest problem of early capitalism - the underproduction of basic inputs, especially fuel, fibres and timber, for the centres of commodity production" (Moore 2007, 2010a/b). What might be most important about recognizing Marx's theory of underproduction is that in doing so, one is also acknowledging what lies underneath much of Marx's analysis is an inherent ontology of 'humanity in nature'. That is, at no point does Marx write about society and nature as though they are discrete spaces, though he often treats them as discrete subjects of analysis. To the contrary, there is constant reference to the 'intercourse' between 'man and soil' as the source of all capital (Marx 1967a/b, 1973, 1978a, 1978d). To conflate the intercourse between humanity and soil with the relationship between humanity and nature undifferentiated is not only a creative reading of Marx, but is bordering on disingenuousness. In the work of both Marx and Braudel the 'socio-ecological antagonisms embedded in the rise of capitalism' (Moore 2003b) are intimately related to the ever-present antagonisms of town and country. Still there are detractors to this idea. O'Connor, for example, argues:

There are no Marxist accounts of the roles of cultural and ecological changes in the transition from one mode(s) of production to another (others). Cultural changes brought about by the Reformation and the Counter Reformation and ecological change and 
destruction brought about by medieval methods of agriculture, energy production, and construction are all played down or ignored in Marxist accounts of the transition from feudalism to capitalism in Europe (O'Connor 1998: 38).

Not only is this criticism a bit hardheaded, especially considering when Marx was writing, but it is a less than charitable reading of the Marxian treatment of human-nature relations. Marx was not 'ignoring' the ecological changes, he was simply not equipped to analyze them at the level they needed to be. After all, the word 'ecology' barely made the academic lexicon by the time Marx and Engels were doing their work, and certainly it was not applied to the human. For that he relied upon Justus von Liebieg, and to some extent Charles Darwin (Foster 2000). Instead, what Marx was focused on was how in fact these ecological regime changes were affecting the way in which humans 'reproduced the means of subsistence' in the post-feudal order versus other periods (Marx 1973).

At the risk of finding ourselves in the black hole of the debate over how to value labour, we must nevertheless engage how labour was appropriated and valued in its more primitive sense, for the agricultural revolutions of the long sixteenth century (circa. 14501640) and the long seventeenth century (circa. 1550-1750) were only possible through a rapid increase in agricultural productivity. David Harvey outlines an important point about Marx's views on the accumulation process within his broader analysis of the 'value of labour power':

Marx rejects outright all formulations that immutably fix the value of labour power (such as the physiological subsistence wage) or the share of variable capital in total output (such as the so-called 'labour-fund' theory) on the grounds that 'capital is not a fixed magnitude, but is a part of social wealth, elastic and constantly fluctuating', and that labour power forms one of the 'elastic powers of capital' which must likewise be construed to be in perpetual flux (Capital, vol. 1: 609) (Harvey 2006: 55). 
The banking of labour power is only possible by a differentiation between certain forms, and the abstraction of that labour power into something not necessarily immediately transferrable. That abstraction is considered by Marx to be a 'social process'. In a footnote of Capital, vol. 1, he states "we are not speaking here of the wages or the value that the labourer gets for a given labour time, but of the value of the commodity in which the labour is materialized" (p. 44), for there was not yet a separated market for one's labour power. It was, and arguably remains, a 'social process that goes on behind the backs of the producers'. That social process is one in the same with the social process of the valuation of commodities on the market. One does not buy a commodity based upon the amount of labour time embedded in the object. This has, since at least the early phases of feudalism, not ever been the case. Valuation is always a case of social negotiation, usually mediated by the state in coalition with the owners of the capital necessary to pay forward the costs of reproduction of current labour and future labour. In the current version of capitalism, the value of a commodity is so far removed from the value of embedded labour, one can scarcely consider it. A fine way to accumulate labour power, or what Marx referred to as 'abstract labour', is by transforming the way in which food is processed.

We must examine, briefly, the role of abstract labour in the process of capital accumulation. "Abstract labour comes into being," according to Harvey, "through a process that expresses the underlying unity of both production and exchange under a specific capitalist mode of production" (2006: 59). This is a profoundly important aspect 
of decoding the exceedingly complex network of relations between labour, production, accumulation, and distribution. As stated in the Grundrisse, abstract labour -

develops more purely and adequately in proportion as labour loses all the characteristics of art; as its particular skill becomes something more and more... irrelevant, and as it becomes more and more a purely abstract activity, a purely mechanical activity, hence indifferent to its particular form (p. 227).

In other words, as labour becomes nothing more than the process by which commodities are produced, it thereby becomes an abstract idea, something only socially embedded in commodities, versus something mathematically or otherwise objectively implied and accounted for, beyond the basic reproduction of the worker. In essence, the new method of measuring labour productivity is through the neoliberal concept of units of labour cost, as opposed to units of labour embedded. In the old agrarian societies, labour was precisely the way in which goods were valued, whether overtly or less directly implied in the exchange. Previous to the use of the money-form of value, we could actually say that the labour embedded in the production of any exchangeable good was the maker for said good's value. This is precisely what changed when labour was extracted out of the equation of how to negotiate prices. If workers could be fed, clothed, and housed - hence reproduced - at a lower cost by feeding, clothing, and housing them more cheaply, the owners of capital could therefore produce more, faster, without the need to reproduce more workers. The labour of the stamper becomes equivalent to the labour of the undertaker, as long as both the stamper and the undertaker can be reproduced for the same amount. However, what remains in question is the amount of production garnered from each of the labourers. "Indifference to specific labours corresponds to a form of society in which individuals can with ease transfer from one labour to another, and where the specific kind is a matter of chance for them, hence the indifference... Such a state of 
affairs is most developed in the most modern form of existence of bourgeois society - in the United States" (Marx 1973: 104-05). This all spells the death of 'skilled labour' and the birth of 'simple labour', which we can simply identify as generalized labour, for it denotes the kind of labour that requires no advanced skills.

The advent of advanced agro-economic development during the long sixteenth century is precisely the point at which labour begins to be so homogenized that it ceases to be a defining factor in production beyond the basic question of whether a particular producer has enough available labour, versus the right kind of skills necessary for that labour. It is, for all intents and purposes, the beginning of the alienation of one's labour to the process of social valuation of the commodities it produces. On this issue, Marx states in Capital, Vol. I:

Some people might think that if the value of a commodity is determined by the quantity of labour spent in it, the more idle and unskillful the labourer, the more valuable would his commodity be, because more time would be required in its production. The labour, however, that forms the substance of value, is homogeneous human labour, expenditure of one uniform labour-power... The labour-time socially necessary is that required to produce an article under the normal conditions of production, and with the average degree of skill and intensity prevalent at the time (p. 39).

When the agricultural production regimes of pre-eighteenth century industrializations are changed for the agricultural regimes of post-enclosure, we begin to see a massive concentration of labour in towns and centres. "Private property exists only where the means of labour and the external conditions of labour belong to private individuals" (Ibid: 761). Agriculture itself went from being primarily collective, and in some cases rather anarchistic, in pre-feudal Europe, to primarily enclosed and organized by private capitalist interest, bolstered by the state - wherever there was a discernable one, clearly marking the beginning of a long capitalist revolution. Coinciding with the rise of 
feudalism, coming directly out of what Marx called the 'second form of property ownership' (Marx 1978d), we see the advent of the 'landed', the 'third form'. "Like tribal and communal ownership (the second form), it is based again on a community; but the directly producing class standing over against it is not, as in the case of the ancient community, the slaves, but the enserfed small peasantry" (Ibid: 153). There was, as of yet, no discernable division of labour. Eventually this would change, but not without multiple agricultural revolutions, allowing for a level of specialization not possible, nor necessary before.

Withe rise of feudalism came the rise of a great many problems, usually beginning with labour. There can be little debate over the very basic fact that with most any social formation, labour is organized in a way that is supportive of the established forms of property, profit and power. O'Connor gives a very solid overview of some of the less desirable labour attributes of the feudal era:

In the European feudal epoch, the serf form of labour produced unique patterns of land use and ecological change. On their own lands, serfs were relatively good farmers; on the demesne of lord's land, where they were forced to work to produce a surplus to maintain a landed aristocracy and feudal superstructure, more often than not they seemed to have worked poorly, and the demesne suffered ecologically... In early feudalism, when meat and grain were produced for local markets or direct consumption, most commons were maintained in a relatively healthy ecological state (1998: 26-27).

The organization of labour, particularly that which is attached to the cultivation of soil and its crops, has had throughout the history of humanity a profound effect on the longevity of chosen production methods. As O'Connor astutely reminds us, "Slave labour gives you one kind of nature; serf labour another kind" (Ibid: 27). Feudalism, in this sense, is again very interesting and troubling, because the labour of the serf is akin to that of the slave, at least in regard to the rights of the workers to the fruits of their 
labours. Of course, we cannot compare European feudalism with American chattel slavery, for there are geopolitical powers and physical domination at play there that were not as overt in the eleventh to sixteenth centuries. On this front, the New World stood on its own as the world's most advanced slaving frontier, thus the most brutal, profitable, and lacking of respect for labour. This is precisely why we must look deeper at the ecological footprint, if you will, of the mode of organization of labour in a given historical period. Obviously, it is way beyond the scope of this paper to go into much depth on that front, but what we can do is look precisely at the fall of feudalism, just toward the middle of the fifteenth century, for that is when the feudal ordering of labour upon the land began to fall apart. It is a story that begins with agricultural revolution.

\section{On Agricultural Revolution and 'Metabolic Rift'}

An 'agricultural revolution' is not to be confused with farmers revolutionizing the mode of production to their benefit, for it is precisely the opposite. Agricultural revolutions typically occur because the owners of agricultural capital require an intensification of the production process in order feed the growing industrial army of workers. To understand this piece of historical capitalism, we have to engage what John Bellamy Foster has called Marx's theory of metabolic rift'.

The interactive relationship between humans and nature; the dance between matters, is the root of what Marx referred to as social metabolism, or Stoffwechsel (Marx 1967, 1978d) when describing the 'social metabolism' of the commodity exchange process, or the process of the movement of commodities from hands who have no use for them to hands that do. Matter, for Marx is constantly reinforced in his theory of social 
metabolism as the most important constituent element of the social process of production, even referring to it as the "social circulation of matter (Ibid)." This is, for Marx, not only an exchange between labourer and purchaser, but initially between raw matter (extrahuman nature) and human matter (nature inclusive of humans); it is the process of humans shaping matter into useful objects through the utilization of their own labourpower. Simply put, the interaction between human matter and non-human matter can be examined as a metabolic relationship that exists between the human and the non-human, or between the sentient and its negation. The discursive paradigm of metabolic relations between "town and country," as Marx understood it, is a very useful platform for learning to view capitalism as world-ecology. More importantly at this juncture, this view of social metabolism brings to the light the complex social assemblages between humans, labour, soil, and eventually machinery.

Stoffwechsel is the most evident start to Marx's underlying knowledge framework of humanity's interactive relationship with nature, but it is equally necessary to look, if only tersely, at the conjoined concept of an 'irreparable break' in the social metabolism, what John Bellamy Foster et al refer to as a rift. ${ }^{12}$ The term rift occurs but once (and only in the Penguin Classics version of Capital, Volume III) in all of Marx's writings. I choose to use the phraseology of "an irreparable break in the coherence of social interchange" as my point of departure. Regardless of the particular interpretation of the Marxian view of social metabolism one takes, it is of central import to the discussion at herein:

\footnotetext{
${ }^{12} \mathrm{It}$ is important to note here that the term "rift" is used the Penguin Classics version of Capital, Volume III. It is my contention that the International Publishers version is far superior and more accurate to the original intent of Marx, because it is in fact a direct reprint of the original Engels edition. In the work of John Bellamy Foster, Richard York, et al, otherwise known as the metabolic rift viewpoint, they take the term presumably from the Penguin Classics version.
} 
Small landed property presupposes that the overwhelming majority of the population is rural, and that not social, but isolated labour predominates; and that, therefore, under such conditions wealth and development of reproduction, both of its material and spiritual prerequisites, are out of the question, and thereby also the prerequisites for rational cultivation. On the other hand, large landed property reduces the agricultural population to a constantly falling minimum, and confronts it with a constantly growing industrial population crowded together in large cities. It thereby creates conditions which cause an irreparable break in the coherence of social interchange prescribed by the natural laws of life. As a result, the vitality of the soil is squandered, and this prodigality is carried by commerce far beyond the borders of a particular state (Liebieg) ${ }^{13}$ (Marx 1974: 813) (emphases added). ${ }^{14}$

This is a clear indication that he believed the conditions already present created the break, and these conditions were exacerbated by the advent of private land ownership, which he saw "as a barrier and hindrance to agriculture" (ibid) itself. I argue, in concert with Moore, that we ought not assume Marx suggested that there is a grand metabolism as put forward by Foster et al. To the contrary, I posit that Marx saw humans and nature as discrete subjects of analysis only in a dialectical sense. That is, in the end of the dialectical inquiry, he returns to a 'humanity in nature' ontology, as opposed to the 'humanity plus nature' ontology.

What today we might call rural to urban labour migration, is what Marx pointed to as the irreparable break in the metabolism between society and the natural laws of life. In other words, the break is between humans and the laws of nature, not between humanity and nature itself. This may constitute a hair-splitting argument, but it is the splitting of the hair of a mammoth. Most importantly, this seemingly minor differentiation between whether Marx argued from an ontological positioning of

\footnotetext{
13 Refers to Justus von Liebieg, who was an agricultural chemist whom Marx was rather obsessed with around the time he wrote much of Volume III of Capital.

14 The irreparable break is easily interpreted in ways not clearly meant by Marx. Differentiation among the modes of production and the relations of labour between town and country is engaged head on by Marx, but what remains in question is if he was also asserting that this break constituted a rift in what could be understood as a grand metabolism between two discrete systems. Of equal import in the above passage is that he points to 'the conditions that cause' this break.
} 
'humanity in nature' or 'humanity plus nature' is crucial to building an interpretation of Marxian social metabolism that is most applicable to the problems of postmodern history, and historically accurate to the best of our efforts to understand his work a century and a half later. Marx states in The German Ideology, that:

The first premise of all human history is, of course, the existence of living human individuals. Thus the first fact to be established is the physical organization of these individuals and their consequent relation to the rest of nature. Of course, we cannot here go either into the actual physical nature of man, or into the natural conditions in which man finds himself - geological, orohydrological, climatic and so on. The writing of history must always set out from these natural bases and their modification in the course of history through the action of men... The way in which men produce their means of subsistence depends first of all on the nature of the actual means of subsistence they find in existence and have to reproduce (emphasis added) (Marx 1978, 149-50).

It is clear in this passage, perhaps more so than in others, that he clearly viewed humanity as part of nature, not as apart from nature. "All production is appropriation of nature on the part of an individual within and through a specific form of society," (Marx 1973, 87) he argued. Therefore, following the beat of Marx, we cannot afford to underestimate the importance of the way in which the reproduction of the means of subsistence is achieved.

In light of the 'underproduction of basic inputs' we must ask how that underproduction is to be transcended in a way that does not either decrease the rate of production or require a rise in the cost of labour. On this point, Marx adds much to the discourse, particularly in his work on rise of machinery and the resultant alienation of man's labour, and the connected surpluses that go to Mr. 'Moneybags' (Marx 1967a, 1973). In other words, while he laid out the basic tenets necessary to understand that there was in fact a negative relationship between the rate of commodity production and that of the replacement of the necessary raw materials for said production, he nevertheless did not move to the obvious next step, which was to devise an ecological 
theory of capitalism, and hence O'Connor's critique of pre-ecological Marxism above.

This is where the work of Moore and others is adding to the impending paradigm shift.

Moore states,

The English agricultural revolution of the long seventeenth century - our classic frame of reference - was not 'simply' the expression of convertible husbandry, new drainage systems and so forth, but could only proceed on the basis of a double movement of geographical expansion: an 'inner' conversion of nitrogen-rich pasture into arable land (therefore opening an expansive nitrogen frontier) within England (Overton 1996); and an 'outer' conversion of the English Caribbean into plantation monocultures, in sugar above all (Dunn 1972). English, then British, capitalism thrived on the basis of this double movement. The Industrial Revolution took shape on its basis, the first movement issuing labour surpluses (Brenner 1976), the second, capital surpluses (Blackburn 1997) (Moore 2010c) (emphases added).

Changing the complex ecosystem of a grazing pasture into land meant for the commercial production of commodity crops is the production of nature in motion. That is, only with massive alterations in the agro-ecological make-up of land, can the rate of accumulation of capital rise, while also sustaining the necessary rise in labour power. We might say that the whole history of the development of capitalism rests upon the reorganization of agricultural, and therefore food, regimes toward profit-seeking ends. As the great Karl Polanyi once stated, "What we call land is an element of nature inextricably interwoven with man's institutions. To isolate it and form a market for it was perhaps the weirdest of all the undertakings of our ancestors" (1992: 187). This is exactly what we are talking about when we are converting field ecosystems into ecosystems of agronomic production. O'Connor writes, "From one perspective (that of the capitalist), ecology is subordinate to human ecology; from another (the ecological Marxist), human ecology i subordinate to ecology. This suggests that there is some kind of dialectical relationship at work between human production and nature's production, or human economy and "nature's economy" (1998: 25). I would take that one step further and suggest that human production is 
nature's production, for one is impossible without the other. All of the raw materials needed for the expansion of production are eco-dependent, which is to say, none of them can be created out of nothing. They must all be extracted from something in order to be used to create something else. Man cannot make matter, only shape it.

The role of agricultural regimes, and particularly agricultural regime changes, cannot be overemphasized in our quest to better understand the rise of the Industrial Revolution. From an agricultural standpoint, that 'rise' has taken place over a much longer span of time than most historians are prepared to accept. Braudel's conception of 'agricultural choice' (1977: 11) is explanatory here, for he point out that there are clearly certain crops that have been chose over others, and for clear reasons that connect with the rise of the capitalist world-economy. Wheat, rice, and maize - "the 'plants of civilization'" (Ibid: 107) - "exerted a strong influence over the fate of European, East Asian, and American civilizations," further argued by Braudel (1977: 11-12):

Europe chose wheat, which devours the soil and forces it to rest regularly; this choice implied and permitted the raising of livestock. Now, who can imagine the history of Europe without oxen, horses, plows, and carts? As a result of this choice Europe has always combined agriculture and animal husbandry. It has always been carnivorous. Rice developed out of a form of gardening, an intensive cultivation in which man could allow no room for animals. This explains why meat constitutes such a small part of the diet in rice-growing areas. Planting corn is surely the simplest and most convenient way to obtain one's "daily bread." It grows very rapidly and requires minimal care. The choice of corn as a crop left free time, making possible the forced peasant labour and the enormous monuments of the Amerindians. Society appropriated a labour force that worked the land only intermittently (Braudel 1977: 11-12).

Braudel's larger point was not to simply explain why certain foods became staples as opposed to others in certain parts of the world. His point was to show that agronomic choices lead to changes in socio-ecological organization. Rice, for example, "holds the world record for the amount of manhandling it requires," he argued (1981: 145). 
Changes in agricultural regimes naturally lead to changes in food regimes, often amplified or instigated by state intervention. In the case of China, they have historically been able to keep a large portion of the population rural, because of the demand for labour in the rice-growing regions. A single hectare of wheat planted in 18th-century France yielded 1.5 million calories for human consumption, while in East Asia that same hectare, but of rice, yielded 7.35 million calories (Ibid: 151).

There is, crucially, a biophysical feedback loop between changes in agricultural regimes and the health of the soil, as there is between the health of the soil and the health of a given society. Disruptions in this process can lead, and have led over the course of history, to countless crises. In the case of wheat, the chosen crop for most of Europe in the early run up to the Industrial Revolution, Braudel argued that its "unpardonable fault was its low yield; it did not provide for its people adequately" (1981: 120), and it tended, as it does still today, to completely ruin the soil, robbing it of all the necessary nutrients needed for its own regeneration. But alas, it was a dominant crop regime that aided in the accumulation of power. Because wheat fields must constantly be rotated, year after year, the only way to avoid always having fields in fallow was to introduce increased productive grazing. And with this change to the agricultural regime, Europe found itself with "considerably greater" animal power "than Africa's and Eurasia's other civilizations, not to mention the America's" (Ibid: 341-352). This was, according to Moore, "a decisive advantage in (and even impetus to) Europe's conquest of the New World (2003b). In short, wheat, and the other new crops that were being developed to feed the growing army of industrial workers - an army that was increasingly beginning to travel long 
distances under the auspices of colonization - were one way to transcend the ecological limitations to capital accumulation.

It is crucial at this point that we turn back to sixteenth century Dutch capitalism, for the dominance of the Dutch world-economy at that time was only possible as a result of a massive advance in shipbuilding technology, technological advancement that could only be achieved with the abundant supply of, you guessed it, 'Norwegian wood'. Norway is famous for their hardwood trees, and even to this very day, the Norwegians make some of the sturdiest and most sea-worthy wooden ships in the world. Moore states,

Wherever Dutch capital set ashore, it set in motion new commodity frontiers in grain and timber... One needn't postulate a continental forest crisis to see that these commoditycentered environmental transformations were implicated in recurrent waves of capitalist expansion across northern Europe. These transformations owed much to the remaking of the New World political ecologies - not only through the connection with silver frontiers ${ }^{15}$, but also thanks to a trans-Atlantic trade pivoting on the sugar/slave nexus (2010b).

The movement of Dutch shipbuilding prowess across the greater Atlantic, fueled by the New World and its connected slave trade, leaves little to the imagination as to how in fact the capitalist frontiers of the 'pre-industrial' world were so greatly expanded in the North Atlantic. We see here both the horizontal expansion of the slave and shipbuilding frontiers, as well as the vertical expansion of the silver frontier, thanks to the colonization of the New World. Let us also be reminded that the previous silver frontier was in the Andean mountains, so this was, even then, nothing new.

The advancement of the Dutch went hand in hand with the agricultural revolution of the North Atlantic in the sixteenth century, a revolution that stretched all the way to

\footnotetext{
${ }^{15}$ See Chapter three.
} 
the Danzig region of Norway, where the wild, relatively untouched hardwood rainforests began to be scientifically organized to produce the woods the Dutch shipbuilders so badly wanted. All of this, again, coincided with the New World silver and sugar frontiers, both of which were dependent upon free labour. But perhaps even more important was the fact that the socio-physical conjunction of the silver and sugar frontiers and the Dutch agricultural revolution was able "to drive forward a series of cascading environmental transformations, widening and deepening a specifically capitalist geography of production and exchange in the North Atlantic" (Moore 2010b), all long before the Industrial Revolution was even remotely imaginable. Nevertheless, the growth rate of this period of Dutch capitalist expansion is quite amazing even by today's standards, and even by the standards of the late eighteenth and nineteenth century. The expansion of Dutch shipbuilding between 1500 and 1700 remains legendary, for its tonnage increased by ten times, but also coincided with a massive penetration into southern Norway, a clearcutting the Norwegians have yet to completely recover from (Sella 1974; Unger 1992, 260-1). Norway essentially became a harvesting center for Holland's timber needs after 1570 , but it did not last much longer. Norway itself began to run out of timber (implicating another potential ecological crisis) and began harvesting from Poland and Lithuania to feed the Dutch demand, demand that was based on the development needs of the New World (Malowist 1960: 36, 39). Channu is content to take that argument much further, arguing that 'a crisis of timber' in the 'great structural crisis' of the seventeenth century Atlantic: 'Was not this crisis of timber an important characteristic of the general crisis that joins these tow centuries' (Channu 1960: 43; Moore 2010b: 199)? The 'great 
structural crisis' of the seventeenth century is strong language indeed. So we must ask, why is it we have so rarely heard anything about this in politico-economic discourse? I don't propose to have a succinct answer, but the question nevertheless must be addressed somehow, somewhere. This paper is at least a start to a potential dialectic.

Lastly, lest we go too far down the rabbit hole that is the development of Dutch capitalism, we must look at the socio-ecological transition that came about as a result of the Dutch advances across the North Atlantic. The first great logging boom of the modern era was created as a result of the advance of Dutch capital (Sevetdal and Grimstad 2003: 14). Norway's logging boom started in the 1550's with the arrival of the Dutch on her southern edge. 'Sawmills spread like wildfires', quickly wiping out many key forests. Moore summarizes the nature of the Dutch miracle thusly:

It was a virtuous circle with a vicious underbelly. For the socio-economic history of Dutch success was enabled by a socio-ecological history of productivity and plunder in one resource frontier after another. This was decisive to the emergence of the Global North Atlantic. It was a logic of ecological hit-and-run. Hit where the ecological wealth was most accessible (cheapest), extract it as fast as possible, then move as quickly as possible once declining ecological returns registered falling profitability (2010b).

The Dutch miracle of the seventeenth century, to take the colorful phraseology of A.D. Chandler, falls into the grouping of "economies of speed" (1977). Economies of speed depend upon resources that evolve through geological time, not human social time. It is a temporal trap that is nearly impossible to surmount without the outright stealing and expropriation of both human and extra-human nature.

By the middle of the seventeenth century Dutch timber imports from Norway 'declined from 130,000 lasts, approximating 260,000 tons, to just 38,000' (Sicking et al. 2004: 7). The Dutch began to experience a kind of economic stagnation they had not seen in over one hundred years, so much so that they event began to employ classic 
mercantilist policies to keep the Norwegian timber flowing directly to them, and only them. It was arguably a power play, for if Norwegian wood were to go anywhere else, Dutch economic hegemony in Europe would be directly challenged. The Rhine valley, the original locality for wood resources, was encumbered by the complexity and high taxation (in the form of tolls) of the river routes, so it is no surprise that Norwegian and Baltic timber displaced it. However, the problem that arose was becoming evident in Norway's reduced timber output. It was a century-long exploitation of Norwegian wood that made the Dutch miracle possible, and as early as the 1660s, we begin to the socioecological effect. In short, "Denmark was, in other words, a kind of poor man's Spain; Norway, a Scandinavian Peru," according to Moore (2010b). "Thus did the political ecology of world power in the eighteenth century reinforce and reproduce the tendency towards the 'sequential overexploitation' (Gadgil and Guha 1992) of one commodity frontier after another" (Ibid). It is ultimately through this example of Dutch economic hegemony in the sixteenth and seventeenth century that we can begin to view capitalism not simply as an economic system, but a system for organizing the available ecosystemic and human resources geared toward a system of endless accumulation of capital. The seeming inability of postmodern society to organize itself thusly is a crisis in itself, for we are in the midst of several mass extinctions events (Lewontin and Levins 2007: Ch. 8).

Socio-Ecological Crises and the Rise of the Capitalist World-System 
In the postmodern age, crisis has taken on a strange and messy composition, in that it means entirely different things to different people in different subsets of global nature. We will not figure out here, within the necessary confines of this paper, definitively what 'crisis' is or is not. What we can do however is to coalesce around a central understanding of the idea that easily travels in both 'social' and 'ecological' space. Moore states that "The signifier 'ecology' (and its cognates such as ecological regime), refers to a holistic perspective on the society-environment relation in a way very close to how the philosopher-botanist Theophrastus deployed the Greek word oikeios: 'to indicate the relationship between a plant species and the environment' (Hughes 1994: 4, emphasis added). The relations are at the centre. If organism and environment constitute the parts, ecology signifies the whole that emerges through these relations" (Moore 2010b).

Further, what Moore wants us to do is to re-think how we 'think capitalism' (Ibid), and the connected concepts of modernity, colonialism, and the other 'master processes' (Tilly 1984) that make up world-history and the myriad transformations along the way.

It can rightly be asserted that agricultural revolutions usually precede ecological crises. By 'agricultural revolution', I mean something not altogether different from the conventional view of industrialization, in that it is signifies the replacement of one dominant form of agricultural production with another. Moore argues that, "The crucial point is that each agricultural revolution moves beyond a series of modest technical adjustments that yield incremental gains to realize a great leap forward in the provision of cheap food, thereby enabling a revolutionary expansion (and subsequent, low-cost reproduction) of the world proletariat that accompanies a new long wave" (Moore 
2010c). What now becomes clear is that at the root of the agricultural revolutions of the long seventeenth century, and all the ecological crises that followed, is one central idea that Moore calls 'the four cheaps' - cheap labour-power, food, energy, and raw materials $(2012,2014 b)$. Every revolution in agricultural production was, and is, based upon the capitalist necessity of these 'four cheaps'. "Capitalism's basic problem is that capital's demand for cheap natures rises faster than its capacity to secure them" (Moore 2012), again bringing to the forefront of our discussion Marx's 'general law' of 'overproduction', which we can recall is also his theory of 'underproduction' (Marx 1977: 376). In the case of agricultural revolution, there is an overproduction of machinery that can speed up the process of cultivation of soil, and therefore the commodities of agro-industrialism, while there is an underproduction of the basic raw materials necessary for the production of the machines, and indeed the workers who will produce them and eventually use them in the very factories that replace their agrarian lifestyles.

Taking things to a much more present tense, there is perhaps no greater example of an agricultural revolution, as explained by Moore above, than what is frequently referred to as the Green Revolution of the 1960s. Leading up to the globalization of the American Green Revolution blueprint, we took our cues from the post-Second World War revolution in agriculture that came about in the mid-1950s, with the passage of 'US Public Law 480' in 1954, as with Khrushchev's dogged pushing forward of Soviet cereal grain production in 1953. The American style Green Revolution not only continues today at the hands of transterritorial mega-corporations like Monsanto, Cargill, Dow and others, but even during the massive global recessions of the 1970s, the 'national farm 
sectors' that the Green Revolution brought on line provided continuously strong yields for the next decade. And it was that success that the neoliberal agribusiness sector was able to capitalize on via the development of new global 'agro-export zones' (McMichael 1997, 1998; Tilman et al. 2002). This confirms Moore's basic hypothesis that "a revolutionary expansion of the food surplus" came "during a revolutionary expansion of the world proletariat" (2010c). If this is not enough to persuade the reader, consider the fact the average real price of rice, maize and wheat plummeted 60 percent between 1960 and the turn of the century, while the world trade of staple foods like rice, maize and wheat tripled between the years 1952-72 (FAO 2002: 11; Warman 2003: 203). In this sense, Green Revolutions have their own longue durée, and that is evidenced by the 'sociophysical conjuncture' of the fall of European feudalism and the rise of the European world-economy, the certain precursor to Wallerstein's capitalist world-system and Moore's 'capitalist world-ecology' (2003b, 2007, 2010c/d, 2011b, 2014b).

Now we return to the crisis of feudalism. Only very rarely, within the worldhistorical discussion of the transition from feudalism to capitalism have the socioecological paradoxes of the medieval expansion been adequately taken into account. It may in fact be more accurate to say that socio-ecological contradictions have played the role of ghost in the machine of historical capitalism. As Moore (2002a) suggests, Wallerstein probably went the furthest in this regard, as he carefully narrated the crises of the fourteenth century as a "socio-physical conjuncture" (1974: 35). However unique and important that phraseology may seem, it did not go far enough, for he did not seek to challenge the rather determinist notions of the dominant narratives of deep green 
environmental theory and history, pointing to "some combination of climate and topography... as major factors in the "rise of the West" (Moore 2002a). The 'rise of the West' mentality leads not only to letting all of the rest of history off the hook for the development of historical capitalism and all its socio-ecological mishitting, but it also continues the vulgar notion of humans acting upon nature, as opposed to acting within nature, as part of the intricate web of life. It may sound like some kind of hippie notion of being 'one with nature', but I assure the reader, it is far more than that. The worldecological viewpoint being put forward by Moore and others begins with a 'humanity in nature' ontology, as mentioned earlier. This is a point I will take up at length in the next chapter. In short, the world-ecology viewpoint puts forward the notion of 'capitalism as world-ecology', versus the more normal structuration of capitalism as simply an economic system with an attached environmental history.

The theoretical transition between a capitalist world-system and a 'capitalist world-ecology' is an exercise in unraveling closely interrelated and interdependent processes and systems within the larger web of life. That transition, I argue, has been underway for some time, but because it has happened primarily within the worldhistorical perspective, spearheaded by Braudel and Wallerstein, we have seen very little movement within what we might call the politico-economic sphere. Strangely, it has also not taken hold in any truly noticeable way within what environmental history and redgreen political theory, where there is more interest in regional and local treatments of capitalism and ecology than in globalist treatments. Chew and Friedman suggest that within the world-historical perspective, there is a rather broad consensus that 
Wallerstein's appropriation of Braudel abstracted environmental questions in favor of social history (Chew 1997, 2001; Friedman 2000). Moore's analysis of Wallerstein over two decades has painted quite the opposite picture, suggesting that not only did Wallerstein incorporate Braudel's historical materialism in general, but that he built that into a "world capitalist development in ways that deepened our understanding of capitalism as an ecohistorical system - as world-ecology as well as world-economy" (Moore 2003b). Moore's world-ecology synthesis is the theoretical name for, among other things, the process of taking Wallerstein's "Marxist economic history and Braudelien environmental history" and enriching that combination with a "reexamination of Marx's analysis of capitalism's socio-ecological contradictions" (Ibid), which is precisely what so few supposed 'Marxists' have attempted to do. One of the most important contributions of the world-ecological perspective is its technique of backtracking into the core Marxian literature to uncover, and in many case recover, what is undoubtedly an ecological basis to entire Marxian canon. We owe a debt of gratitude to the work John Bellamy Foster and the purveyors of the metabolic rift school of thought, but as mentioned early on, it does not go nearly far enough. The world-ecology framework utilizes the best parts of Foster et al argument, but without the convenient negation of the negation of the assumption of a human/nature divide, or what we have also called the 'society/nature binary'.

We cannot, however, leave it that. The implications of an ontological positioning of 'humanity in nature' are numerous, and while well beyond the scope of this paper, we can look at the effect it may have on what Marx called 'socially necessary labour time', 
and other such constructs of what Moore logically refers to as 'abstract social natures'. This is a crucial dialectic of the world-ecology framework. Humanity plus nature can only equal nature, for the latter is a product of the former, and as we have been examining, the former is a producer of the latter through agriculture, labour-power, and commodification. We have smoothed out the edges of this idea throughout the paper, but it is important that we not leave it less than clear. Commodification is the preferred method of the capitalist to reduce socially necessary labour time while still increasing the rate of production per unit of labour-power input. Here we are again reminded of Marx's basic observation that capitalist production tends to overproduce the machinery of production, while under-producing raw materials, ${ }^{16}$ or the substances of the reproduction of the means of subsistence. We need not look any further than the fossil fuel industries for evidence. We build giant excavating dump trucks that are larger than many buildings, which clear the tops of mountains (usually following a dynamite explosion) of the 'waste soil' so that we can get down to the oil and minerals contained deep inside the mountain. Once this 'mountain-top removal' process is completed, the process of capitalization ensues, and within a few years, often less, all the jobs are gone and the mountain's previous ecosystem is never restored (Marley and Fox 2014). ${ }^{17}$ The world-ecology synthesis seeks to clarify capitalization by suggesting that it is "the reduction of sociallynecessary labour time through commodification" (Moore 2013c), and appropriation as

\footnotetext{
16 Underproducing is another way of saying 'not replenishing'.

17 Other examples abound of this phenomenon of producing the mechanisms of resource extraction, including the production of labour, but simply moving on after the point of extraction, never to return those materials back into the earth. In the case of 'working forests' in Oregon and Washington, in example, there has been a concerted movement to replenish the forest after logging, but this is only done at the level of planting new trees, which does little to nothing to rebuild the forest floor, the most important piece of the forest ecosystem in terms of longevity.
} 
"the maximization of unpaid work in service to capitalization" (Ibid). The cooking, cleaning, and child-rearing that was so ubiquitous to the classic 1950s housewife model of American culture is probably the finest example of the importance of unpaid labour to the advancement of the capitalist project, other than slavery.

The post-Cartesian frame has a direct impact upon how we view socially necessary labour time, particularly in regard to unpaid work like that of the 'homemaker'. As Moore states, "This is a simplified model, a "first cut" if you will. We are excavating the fundamental historical dynamics of capital accumulation as a pattern that operates through the specifically bundled relations of human and extra-human nature (the law of value)" (Ibid). If the capitalist can appropriate elements of what we call nature and use those elements to capitalize, thus speeding up the process accumulation more generally, then the same could be said of the backyard gardener, the homemaker, the child-rearer, and whatever other work is useful of nature but not regenerative of nature. The Four Cheaps, argues Moore, "could be restored only partly through innovations within established zones of commodity production; historically, they also depended on new strategies of appropriation, on new frontiers" (2013c), as so much of this paper has already alluded to. In short, we cannot discount the importance of how we think about the metabolism between humans and the rest of nature.

Even though Marx and Engels made this relational subject area a central tenet to much of their earliest work, particularly on the part of ecological Marxists, and even more so on the part of politico-economic thinkers, this piece of the Marxian canon - most notably found in the Grundrisse and Capital, Volume III - has been conspicuously left out 
of most analyses of industrialization and its constituent elements. ${ }^{18}$ The biological and otherwise sciences have also done a remarkably inferior job of addressing the dialectic of humanity in nature versus humanity plus nature. The whole history of social scientific thinking is rotten with false dichotomies.

In the following chapter, the penultimate chapter of this work, I will seek to lay out some of the most basic tenets of the world-ecology viewpoint as I understand them from my reading of Moore's work, as well as that of Braudel, Wallerstein, Arrighi, Harvey, O'Connor, and all the other writers featured thus far. There are at this point no experts on the world-ecology synthesis except for Jason W. Moore, but as I write this paper, he has yet to put out an article or textbook that outlines the entire framework from top to bottom, so this does leave his work open to much criticism, but also to new ways of explaining his work in other ways, while perhaps adding to it. My intention in the following chapter is simply to make a contribution to that process by providing a worldecological redefining of the concept of the Industrial Revolution, a definition that the world-ecology framework may begin to adopt over time, and of course advance along the way.

\footnotetext{
${ }^{18}$ Importantly, many theorists argue that a direct de-emphasization of nature, or ecology, is central to the Marxian ethos; that there existed no discernable critique of industrialization as a desirable or undesirable process. I argue this negation is not so central to the Marxian framework, and that can be easily seen through the numerous writings of Marx on social metabolism, as outlined earlier. Marx and Engels were products of their social, political, and economic surroundings, so it ought come as no surprise that taking control of the reigns of capitalist industrialization and utilizing its power for the building of a 'dictatorship of the proletariat' was the only logical way forward against the counter-revolutionary force of capitalism. To write off Marxism and Socialism as inherently anti-ecological is both misguided and dangerous, for there is ample reason to suggest that many tenets of the Marxist/Socialist frameworks (as evidenced herein) hold great promise for addressing today's socio-ecological crises.
} 


\section{CHAPTER FOUR: A world-ecological re-defining of the Industrial Revolution}

And as with all historiographical fads, the endless contortions engaged in to save the thesis dilute its explanatory power.

- Ian Shapiro (1989)

Early capitalism was indeed real capitalism. Early modern capitalism's ecological regime was on premised on a highly effective combination of military conquest, the vigorous geographical extension of commodity production directly and indirectly, the creation of financial structures that radically accelerated turnover time and sustained economic interdependence on a globalizing basis, and the maximization of technological development oriented towards

geographical expansion. Early capitalism was based on a globalizing ecological strategy that emphasized the radical expansion of the arena for commodity production and market exchange. - Jason W. Moore (2010b)

Writing history equates to principled narration of phenomena across zones of time and

space. The central principle that attends to the narration of historical capitalism, and

therefore the Industrial Revolution, within the world-ecology viewpoint is the perspective of 'capitalism as world-ecology' (Moore 2010a/b):

At heart, this perspective offers a simple proposition: capitalism does not act upon nature so much as it unfolds through nature-society relations. It is a protest against, and an alternative to, the Cartesian worldview that puts nature in one box, society in another (2009c, 2010b). This alternative views the great movements of modern world history industrial and agricultural revolutions, successive 'new' imperialisms, social revolutions, the formation and development of the world market - as socio-ecological projects and processes aimed at reconfiguring nature-society relations within their respective fields of gravity. 'Nature', no longer a passive substance upon which humanity leaves its footprint, becomes an active bundle of relations formed and re-formed through the historically and geographically specific movements of humans with the rest of nature. Capitalism, as world-ecology, first emerged during the tectonic shift in the Atlantic world's locus of power after 1450. It was a shift from power over territory to power over the fruits of commodity production and exchange (Moore 2010b).

In short, 'capitalism as world-ecology' allows us to view historical capitalism as it

actually happened, not as it was supposed to have happened, according to its most grand

purveyors. Further, it examines historical capitalism as environmental history, versus the environmental history of capitalism. 
We have so far examined two distinct, though interrelated narratives of the Industrial Revolution, while alluding to a third, which I will examine momentarily. The first - the one still the most dominant in politico-economic and otherwise historical discourse - is the techno-economic narrative. There are some basic tenets easily extracted from the leading thinkers of this viewpoint, namely that:

1. The Industrial Revolution was a unified, progressive phenomenon that happened during a specific span of time of 1750-1850 (Toynbee 1844; Ashton 1948; Mathias 1969; Thompson 1973; Hartwell 1990).

2. Modernization, or the culmination of the technological advancement and human progress over millennia, is the real driver of the economic and otherwise transformations of the late eighteenth and nineteenth century (Apter 1965; Landes 1969; Mokyr 1990).

3. The 'economic revolution' (Thompson 1973) of the time is considered to be evidence of the rightness of the Smithian liberal economistic argument that "individual motives, however selfish they might be, resulted in benefits to society as a whole" (Fusfeld 2002: 20) (also see Smith 1776; Apter 1965: 46; Bowdich and Ramsland 1961: 12-35, 70-81; Friedman 2002)

4. A view of 'nature' as the provider of 'ecological surpluses' (Moore 2010c) or "the four cheaps" (cheap labour, cheap energy, cheap food, and cheap resources) (2012, 2014b). Also, the view that 'society' is ontologically separate from 'nature'. All of the above tenets have problems of both space and time, which are partially dealt with through the historical-relational thinking of Marx, Braudel, Nef, Cipolla, and 
Wrigley, among others. Spatially, the historical-relational viewpoint adds great depth to our understanding of the importance of the expansion of commodity frontiers, especially that of labour through the slave trade and the conquests of colonization in Asia, Africa and the Americas. Temporally, historical-relational methods offer us the chance to look at history in longer spans of time, while still relating those spans to the present and future. In fact, it might be said that all great historians think in three temporal zones at all times: past, present, and future. Where the techno-economic narratives rarely look at history in less than 50-100 year blocks of time, the relational methods routinely compare blocks of several hundred years. Thus, the environmental world-historical and Marxist historical materialist narratives, together forming our second methodological approach, to the Industrial Revolution suggests that it was/is:

1. A progressive phenomenon, but not necessarily unified, and not always linear in its progressions, technologically or otherwise (Braudel 1977, 1982, 1984, 1993; Arrighi 1994; Wrigley 1988; Moore 2001b, 2003b).

2. Not always, historically, a source of economic growth; it was often the source of economic stagnation in areas where it was not increasing the rate of surplus capital formation (Mathias 1969; Deane 1973, 1979; Bunker 1994; Arrighi 1994, 1998, 2001), as evidenced by the agricultural stagnation of the early eighteenth century in England (Moore 2010b; Deane 1979; Malanima 2006).

3. Only possible with large-scale exploitation of labour (Marx 1967a, 1967b, 1972a, 1972c, 1972d; Schroyer 1971; Wallerstein 1989; Tomich 1997; Blackburn 1997; Moore 2000b, 2002a/b, 2007, 2010d, 2012, 2013c, 2014b), geographical 
expansion of the capital frontier (Moore (all); Harvey 1982, 2003, 2010a; Smith 1984; Arrighi 1994).

4. A phenomenon wholly dependent upon its historical antecedents in the form of 'agricultural revolutions' and the resultant transformations in town-country relations (Marx 1967b, 1973; Harvey 1982; Overton 1996; Foster 2000; Hornborg et al. 2007; Moore 2008, 2009, 2010c, 2011a/b, 2013b, 2014a/b; Mumford 2004). With these tenets added into our analysis of the Industrial Revolution, we move ever closer to developing what is arguably missing in the wider discourse of industrialization and historical capitalism - a way of talking and writing about economic and environmental history as though humans are not metaphysically or in any other way considered separate or hierarchically removed from the rest of nature; based on the ontological position of viewing 'humanity in nature' as opposed to 'humanity plus nature'. This post-Cartesian framework leads us to our third way. We get there first through rethinking our temporal and spatial relevancies over the very long term. Only then can we begin the process of examining the really existing history of capitalism in a way that does not see nature as merely the provider of free raw materials, and humanity as the sole proprietor of these materials. This is precisely where the world-ecology viewpoint drastically changes the confines of the narrative of the Industrial Revolution.

In the previous chapters I have pointed out some of the key differences between the established dominant narratives of looking at our phenomenon. Along the way, I 
have mentioned a few ontological fixes ${ }^{19}$ that may be employed to further examine the phenomenon in a way that is based more solidly in what we might call 'ecopolitical reality'. ${ }^{20}$ What I would like to suggest is that the world-ecology framework, or the worldecology synthesis, is a filter through which we can sift these different narratives, uncovering what is and is not explanatory in our quest to clarify and ultimately re-define the Industrial Revolution. I argue that this paradigmatic shift provides some basic tenets that form a theoretical praxis for examining it not as a unified, progressive phenomenon, but instead as a rhizomatic, expansive world-ecological event, characterized by systemic cycles of accumulation (Arrighi 1994) by dispossession (Harvey 1982, 2003, 2010a) through geographical expansions of the capital frontier (Arrighi 2007b, 2008; Moore 2008, 2009, 2010a/b, 2014b). The presuppositions of the world-ecology synthesis, as it pertains to the Industrial Revolution, are, according to the relevant literature, as follows:

1. Historical capitalism did not cause ecological crises. To the contrary, it is a system that evolved through socio-ecological crisis. Today's biospheric challenges are constitutive of the capitalist mode of production, not consequences of capitalism. "Capitalism, from its origins in the 'long sixteenth century', emerged out of an epochal ecological crisis" (Moore 2000, 2003, 2007; O'Connor 1998). Capitalism, in this view, is an industrial fix to the ecosystemic limitations of capital accumulation.

\footnotetext{
19 These include the 'humanity in nature' ontology, the theory of 'capitalism as world-ecology', and a much altered temporal treatment of the Industrial Revolution - one that sees it beginning much earlier and still with us today.

${ }^{20}$ This is a term I have used frequently in my work, thus far unpublished. While I lay no claim to its origination, I can say with relative certainty that the only other theorist of note to use the phrase is Ingulfur Blühdorn, and his use was only very casual. I point this out so as not to claim originality, but to claim regular usage.
} 
2. The world-ecology synthesis is based on a "unified theory of capitalist development... one that views the accumulation of capital, the pursuit of power, and the production of nature as undifferentiated moments within the singularity of historical capitalism" (Moore, 2011). This makes the case for the Industrial Revolution being little more than one event in this on-going process of accumulation.

3. Capitalism as a world-system appears during the 'long sixteenth century' (roughly 1450-1640), coinciding with the 'crisis of feudalism' (Moore 2002a).

4. A 'humanity in nature' ontology versus a 'humanity and nature' ontology (Marx 1967b, 1973, 1978d; O'Connor 1998; Moore 2013a/b/c, 2014a/b; Lewontin and Levins 2007; Cloke and Johnston 2005: Chapters 1, 3, 8), or what Moore calls a 'post-Cartesian' perspective of nature.

5. The capital accumulation process is dependent upon Biophysical transformations (e.g. global warming, species extinction) over time and space (Lewontin and Levins 2007: 103, 105; Moore in toto). Endless accumulation of capital is only possible if these crises are considered necessary externalities, to be dealt with through 'market-based solutions', a phrase all too common in current history.

If we consider these tenets when looking at the Industrial Revolution over the very long term, it begins to look much more like a 'world-ecological event' than 'industrial revolution'. For the modernist of the nineteenth and twentieth centuries, the phraseology of 'industrial revolution' and the mythos of the Industrial Revolution is more than 
adequate, but for the post-modernist ${ }^{21}$ of the twenty-first century, seeking a more longterm relational understanding of historical capitalism and the rise of the global capitalist system, the Industrial Revolution becomes the focal point of the analysis of the rise of the capitalist world-system. Historical industrialization can then be analyzed as, for lack of a better term, a pre-capitalist notion, for it was indeed capitalism that brought about the Industrial Revolution, what might better be referred to as 'the capitalist industrial revolution'. It is in this sense that the term 'event' is to be used relative to the longue durée. In Braudel's beautiful phrasing, "All historical writing periodizes the past, and makes choices among chronological realities, based on positive or negative preferences that are more or less conscious. Traditional history, which is oriented to brief time spans, to the individual, to the event, has long accustomed us to an account that is precipitate, dramatic, and breathless" (Lee 2012: 244). However, Braudel also posits that, "Indefinitely stretchable, the event becomes linked, by design or by chance, to a whole chain of events, of underlying realities that then become impossible, it seems, to disentangle, one from the other... within every event all of history, all of humankind is contained, and thus can be rediscovered at will" (Ibid: 245). Let us remember this view of the 'event' as we begin to conclude this paper and eventually suggest something more about the future of the Industrial Revolution.

There are three quite distinct lessons we can draw from the above analysis of the core presuppositions of the world-ecology method. First, we can no longer adhere to the two-century model of industrialization. That is, the notion that "it all began with the

\footnotetext{
${ }^{21}$ With this phrase I mean precisely the idea that we have left the historical age we call the "modern" for the new historical age we call the "post-modern." This is not to be confused with post-structuralism or French-school postmodernist theory.
} 
Industrial Revolution" (Moore 2013a). This view negates all of the agricultural regime changes and resultant socio-ecological transformations that came long before the English industrialization of the seventeenth and eighteenth century. It also negates the role of chattel slavery and slave labour in general in the development of the industrial ancien regime of the then 'New World'. And finally, it also assumes that it was indeed 'revolutionary', in the sense that it was a sudden, dramatic reorganization of society, when we know it was anything but sudden. We could also say it was not a reorganization, but an amplification of existing structures, resulting in a capitalocentric approach to production. Only the most vulgar economistic arguments put forward the idea that the Industrial Revolution was a sudden success, quickly swapping one socioeconomic organizational structure with another.

Second, 'industrial revolution' undifferentiated is an entirely different animal than the Industrial Revolution, for the latter - while only possible with the former - is situated within a capitalist infrastructure that did not appear until long sixteenth century, as I have argued thus far. Therefore, again, we cannot accept the two-century model, for we would be engaging in a cherry-picked history of world-historical industrialization; a process that began long before capitalism made its mark upon humanity. To be clear, the Industrial Revolution is not only a machine revolution, or the latest in a long line of other industrial revolutions as suggested by Braudel, but more precisely an ongoing revolution that originated through specifically capitalist relations of land, labour, and resources.

At this very moment China and Russia have coalesced around an energy strategy as a way of continuing China's ongoing industrialization and Russia's desire to have more 
global input. It is a development that some have suggested challenges the dominance of the US export market for LNG (liquefied natural gas), a market the US is clearly banking upon. The United States runs the potential to lose billions of dollars in profits because it has not kept up with export demands, while the Russo-China energy deal becomes another hurdle the US must jump in order to increase its global competitive edge in what is clearly the beginning of a new global energy bubble. According to Richard Martin of Forbes Magazine, "Competition in the international gas markets is bound to heat up, and the United States may have already missed its opportunity for an LNG export bonanza. Expanding pipelines, more export terminals, and better technology for liquefying and shipping natural gas will all help globalize the natural market, in the way the crude oil market is already globalized. Already, the relatively low price that China will pay for Russian gas (around $\$ 350$ per thousand cubic meters, analysts estimate) is putting downward pressure on higher prices for Japan and South Korea."22 China and Russia, along with all the other quickly industrialization nations of the global south and east, have no reason - particularly within a capitalist world-order - to hold economic allegiances to the United States. This is not only happening in Eurasia, but all over the world, where the periphery countries are increasingly doing what they must in order to grow economically, in spite of the socio-ecological limitations to said growth. It is the same ongoing story that began with the fall of European feudalism.

\footnotetext{
22 Richard Martin, "Russia-China Gas Deal Narrows Window for U.S. Exports." http://www.forbes.com/sites/pikeresearch/2014/05/30/russia-china-gas-dealnarrows-window-for-u-s-exports/. Accessed on July 9, 2014.
} 
Third, if we assume a 'humanity in nature' ontology, we are forced with even more historical impetus to examine the earliest examples of geographical expansion, and the quest for capital accumulation that came with them. Ecological change does not adhere to human-invented temporal histories, so with every major expansion we must look back much further to find the origin of said expansion. This is, again, why the twocentury model of modernity - industrial society, industrial civilization, industrial capitalism (Moore 2013a) - must be thrown out in favor of a four century one. In short, our 'humanity in nature' ontology causes us to rethink the origins of our socio-ecological processes, for if we do not, we run the risk of confusing 'environmental' outcomes with processional origins. I argue, in congruence with Moore, that this is one of the prime faults of the 'economic' paradigm in general. For the endless accumulation of capital can only happen if humans are thought to be unaccountable to the ecological surpluses garnered from extra-human nature. As Keynes once quipped, "Practical men, who believe themselves to be quite exempt from any intellectual influences, are usually the slaves of some defunct economist" (Fusfeld 2002: 1). The irony here is that the 'defunct economist' is also the slave to a defunct vision of the way in which humans reproduce the means of subsistence over historical time and space.

The world-ecology synthesis is indeed both linear and relational, for history does in fact line up in linear fashion in some cases, and it is impossible to imagine a plausible historicity of the Industrial Revolution that is not always relational. However, both are nonetheless lacking in their ability to address the socio-ecological foundations of industrialization in general, and even less so in regard to the Industrial Revolution. 
Therefore, they leave unanswered a basic question: If the industrializations of the fifteenth through seventeenth centuries are included in the Industrial Revolution, does that de-legitimize the term, or does it begin to re-define it? I argue it is the latter, with one major caveat. That is, where Braudel suggests that there have been 'four successive industrial revolutions' (1999: 374), with the coal revolution of the late seventeenth and eighteenth centuries being a key indicator, I argue there has really only been one 'industrial revolution', and it is the Industrial Revolution, re-defined as the ongoing capitalist revolution that began during the long sixteenth century. What I have herein referred to as 'industrializations', Braudel and Wallerstein refer to as 'industrial revolutions'. Therefore, I have sought to identify the revolutionary aspect of the industrializations that began in the fifteenth century as capitalist, in that it was indeed the emergence of the capitalist European world-system that separates that period from all the previous periods of industrialization, going all the way back to even the most rudimentary.

I have taken the basic presuppositions of the dominant narratives of the Industrial Revolution, and then filtered those them through those of the world-ecology synthesis, hoping for an updated definition that can be applied to further research that does not depend upon extra-ecological interpretations of capitalist industrialization. My hypothesis was that this filtering process would lead a more clarified explanation of the Industrial Revolution as essentially a capitalist revolution. I believe that the work contained herein does indeed point in that direction. Furthermore, this analysis contributes to the development of world-ecological interpretation of industrialization over 
the very long term, as well as the above critical re-framing of the main subject at hand, while accurately assessing the rise of capitalism - a key foundational piece to our understanding of both phenomena. As of the date of this writing, nobody, including Moore, has yet attempted to critically re-interpret the Industrial Revolution through the world-ecology lens.

\section{General Theoretical Model}

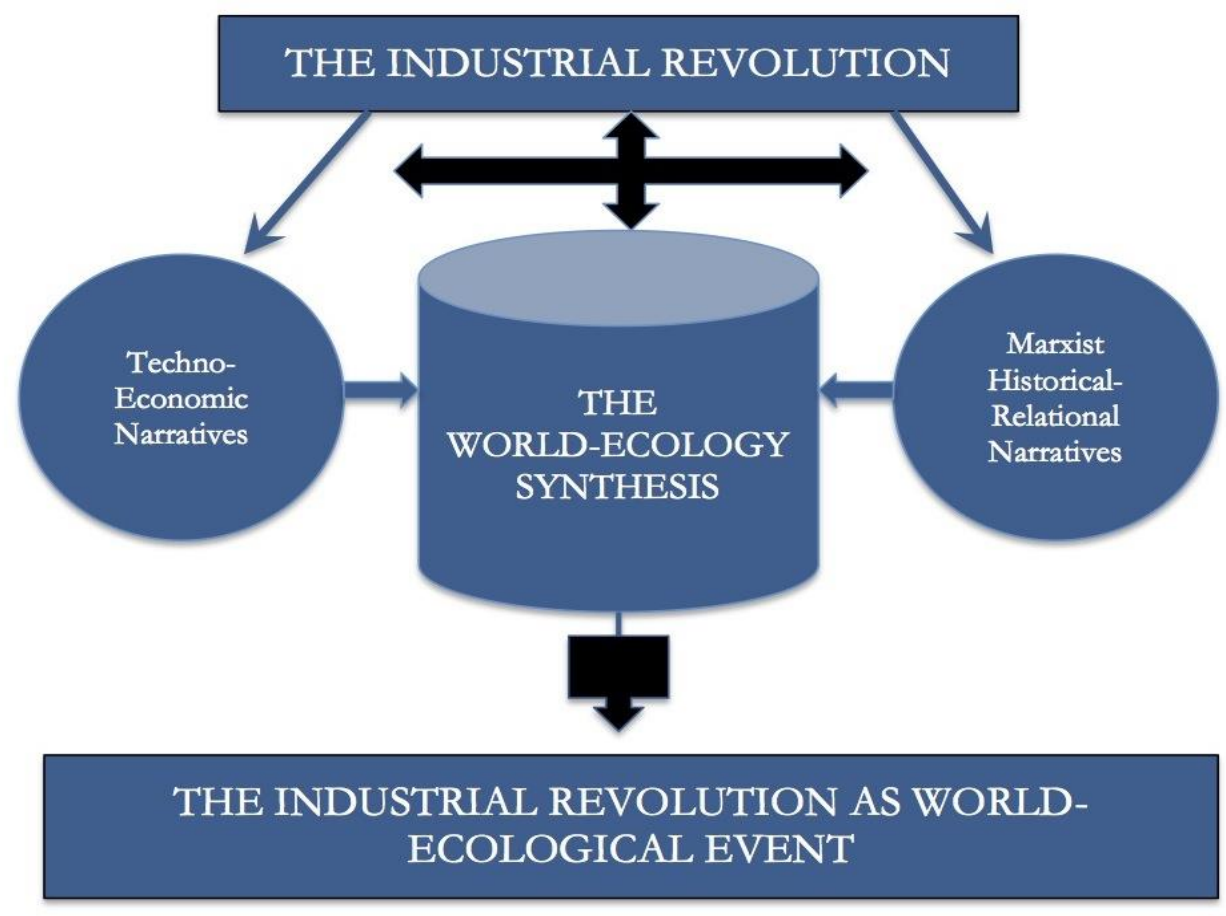

[Figure 1]

The graphic above is meant to give a visual representation of the overall thesis and hypothesis of this paper, outlining the filtering process described earlier. The research undertaken here has led me to precisely the place I believed I would end up, with a critical re-definition of the Industrial Revolution is an ongoing capitalist revolution that involved a period of great intensification during the seventeenth and eighteenth 
centuries for sure, but was, crucially, part of an ongoing world-ecological event that began with the fall of feudalism in Europe and the beginning of the capitalist worldsystem in the long 16th century. Of equal importance is the role of what I have referred to as 'historical industrialization', meaning the various individual industrializations along the way - water, coal, steam, and perhaps natural gas. ${ }^{23}$

Human socioeconomic systems not only depend upon the 'four cheaps' as a method of expanding the capital frontier - effectively engineering a more capitalocentric ecosystem - but that very dependence alters, often irreversibly, the global ecosystemic balance. Capitalism is effectively a system for organizing nature in service to capital, thus it is seen as a world-ecology. By expanding the world-system idea to include ecological dynamics, we begin to develop a view of "nature as matrix, rather than resource zone and rubbish bin" (Moore 2013c). Can it not be argued that viewing nature in this way necessarily challenges the very taproot notion of capitalism, endless accumulation of capital? Moore argues, "Through its alliance with state-machineries, imperialist power, and bourgeois knowledge, capital has proven adept at overcoming real, or impending, "bottlenecks" to renewed accumulation. The frontier has therefore been capitalism's way of paying the bills that run up across successive long centuries of accumulation" (Ibid). In short, the theory of capitalism as world-ecology engages the necessary synthesis of the idea of vertical expansion and horizontal expansion. The former is unavoidably ecological in scope, while the latter is social, economic, and political. Only by merging these two ideas can we begin to see the world-system, as it is

\footnotetext{
${ }^{23}$ This is an assumption at this point, for there is little evidence that natural gas has a long life ahead of it as a prime source of fuel. Nevertheless, the capitalist world-system is already clutching around the expansionary realities of this source, expansion that are both vertical and horizontal.
} 
really operating now, and the socio-ecological transformations that the current worldecology evolved through, leaving us with the knowledge that nothing is not ecological. 


\section{CHAPTER FIVE: CONCLUSION}

The response to a demand that is unrealizable within bourgeois society has been to claim that really new social relations are biologically impossible because human nature is continuous with

a competitive, aggressive, self-oriented, and self-aggrandizing nature built into our nonhuman ancestors by evolution. Nothing really new arose in the evolution of the human species. We are simply "naked apes" possessed of our own species-specific form of unchanged and deeply entrenched animal natures, so attempts to change social arrangements are delusory.

- Richard Lewontin and Richard Levins

Production, then, is also immediately consumption, consumption is also immediately production. Each is immediately its opposite.

- Karl Marx

I know things older than competition and scarcity, abundance for the people who live sustainably; older than free markets, poverty, profit, toxic logic and the magic of an unknown universe... I know a land that's older than borders. Primordial borders gave birth to the landwalkers. Their arrogance made them a casualty of greed. Now they can't sustain life poisoned and mistreated.

- Brian Lozenski, aka MC Brihanu of the band Junkyard Empire

What began in the western world is now another BRIC $^{24}$ in the wall of the facade of the ongoing industrial revolutionary march toward what increasingly looks like a heightened state of global ecosystemic crisis. The momentum of global economic concentration of power is shifting east and south. Brazil and Russia have already established close trade ties, as has China with Russia, with India making stronger movements toward various modernizations. Thus, there cannot be any illusions that the Industrial Revolution stopped in the middle of the twentieth century. Industrialization has been with us from the beginning, so unless we strip the Industrial Revolution of all temporality, we must accept that something drastic changed at some point in the longue durée of worldhistorical industrialization. In this regard, this paper has argued two key points: First,

${ }^{24}$ Brazil, Russian, India, and China. 
that what changed was capital and how it was accumulated; and second, that this change did not happen overnight. To the contary, it began with fall of European feudalism nearly two centuries earlier, during the long sixteenth century. There can be no doubt that there was a massive intensification of industrial infrastructure and technological prowess during the eighteenth and nineteenth centuries. However, we also cannot doubt that the mad pace of industrialization that began with the Industrial Revolution's early phase has not slowed, and arguably is speeding up on multiple fronts.

The increasing speed of the melting of the Greenland Ice Shelf threatens to heat up the Cold War into a full-blown World War III kind of scenario. Why? Because roughly 30 percent of the world's remaining natural gas is underneath that territory, a territory that the Russians, Norwegians, and Americans all think they ought to control. ${ }^{25}$ The world-economy itself has suffered what some have begun to call the Great Stagnation. ${ }^{26}$ If we think back to our discussion of early English industrialization, we will remember that the holy grail of 'economic growth' was rarely unified and progressive. Like the ecosystems that economic growth relies upon, growth patterns are frequently obtuse and sudden, as are recessions and stagnations. What makes this period in history different, however, is that there has never been so obviously a global economic shift, both downward, in the sense of recession and stagnation, and outward in the sense of geographical reach. Christine Lagarde, the Managing Director of the IMF, asserted in a major speech in China nonetheless, on November 9, 2011 that, "The global economy has

\footnotetext{
${ }^{25}$ For more information on this new development see the June 6, 2014 episode of the show VICE on HBO (http://www.hbo.com/\#/vice/episodes).

26 "From the Great Recession to the Great Stagnation," Forbes, October 10, 2011, http:// forbes.com; tyler Cowen, the Great Stagnation (New York: Penguin, 2010).
} 
entered a dangerous and uncertain phase. Adverse feedback loops between the real economy and the financial sector have become prominent. And unemployment in the advanced economies remains unacceptably high," and that "Asia is not immune" to these problems. ${ }^{27}$ One could also look at that speech and see little more than fear at the very obviously faltering American economic hegemony that so many in the world have relied upon since at least the 1970s. After all, does it not fit perfectly the neoliberal narrative of economic growth that there is no better time to revolutionize industry and profit handsomely from it than during a time when the proverbial industrial reserve army is at its largest and most desperate?

The Industrial Revolution is one of humanity's most troublesome inventions. Maybe 'invention' is not the right word, or is it? Is not the concept of industrial revolution itself the same as the concepts of freedom, liberty, power, agency, justice, and all the other contestable gross concepts of the social scientist; that is, a concept meant to evoke a certain ideation, and therefore an invention of the human mind, like the great inventions of the industrialists? There can be no reasonable doubt that the Industrial Revolution is another of these gross concepts that will forever go on being debated, so let us not get too hung up on settling the score in relation to definitional clarity. Instead, what this paper has been not so subtly suggesting is that how we think the phenomena under examination is always as important, if not more so, than what we think some given phenomenon is or is not. I have attempted to show that this is not a new conundrum either.

${ }_{27}$ Christine Lagarde, "An Address to the 2011 International Finance Forum," Beijing, November 9, 2011, http:/ /imf.org. See also C. Ryan Knight, "Dark Clouds, Over the Boat: On China, Production, and Fiancialization," November 11, 2011, http://lecoupdoeil.wordpress.com. 
With the Industrial Revolution, we are forced to see humanity at both its greatest and its absolute worst. Man's ${ }^{28}$ negation of the ecosystemic realities of the development of historical capitalism into the monstrosity that it is today serves as perhaps the greatest example of his prowess toward self and other destruction. Nevertheless, it is the future we must deal with, now that we have at least a modicum of collective understanding of the ecological affect of capitalism's continuous march toward and through crisis. As the great Daniel McKinley once wrote in the now biblically important text The Subversive Science, "A true account cannot fail to honor mankind, but one wants no shallow anthropocentrisms masquerading as ecology" (Shepard and McKinley 1969: 351). The world-ecology synthesis is one way of seeing and thinking that is anything but an ecological masquerade party. To the contrary, I believe it represents the most important step forward we social and politico-ecological thinkers can make toward the goal of revising history through the lens of ecopolitical reality, and therefore potentially revising how we understand the past and envision the future.

Showing the world-ecology synthesis as a viable method of radically reanalyzing our phenomenon, and maybe even paradigm-shifting mode of analysis, however, is not the goal of this paper. The worthiness of the framework ought to be clear by now; of this I'm reasonably certain. Of much more importance is the use of it to look at the Industrial Revolution through the context of 'capitalism as environmental history', versus 'environmental history of capitalism'. This has not yet been accomplished, and I argue what we have here is a start. Our goal is thus also to ecologize, if you will, our way of

\footnotetext{
28 And in this case I do mean 'man' as opposed to women, or humanity undifferentiated, because as the historical record clearly shows, it is rarely women we have to thank for this epochal oversights that cause the ecological crises through which capitalism so powerfully developed.
} 
seeing such ideations as the Industrial Revolution, for it is the 'ecological' and the 'worldsystemic' that has been so curiously, and I argue detrimentally, left out of the long historical discourse of historical industrialization, with only the exceptions of those thinkers I have attended to throughout this paper. With this world-ecological reanalysis of industrialization over the very long term, viewing humanity in nature versus against, above, added to or in any other way not fully integrated, we can begin to put two very dominant, yet terribly problematic, arguments to bed, once and for all: the Anthropocene and what I have referred to as the human/nature divide. Moore argues, "The problem today is the end of the Capitalocene, not the march of the Anthropocene. The reality is not one of humanity "overwhelming the great forces of nature" (Steffen, et al., 2011), but rather one of capitalism exhausting its cheap nature strategy" (2013c). It might also be argued that utilizing the world-ecological synthesizations (humanity and nature, capitalization, accumulation, etc.) we can also rid ourselves of the mostly absurdist 'ecosystem services' argument. ${ }^{29}$ While it is true that every form of production requires the taking of 'services' from the ecosystem, what Moore et al have called 'ecological surpluses', in order to produce commodities, without a post-Cartesian framework employed in such analysis, we are doing little more than succumbing to some kind of

${ }^{29}$ 'The 'ecosystem services model' of analysis takes a grossly dualist perspective on nature, seeing humanity as the beneficiaries of ecological materials in 'service' to humanity, services we are supposed to replenish not through our social and ecopolitical systems, but through some kind of human obligation. In the end, it is often argued that market-based solutions are the only logical path toward ecosystemic regeneration. See, for example the following works: Heal, G. M. 2000. Nature and the marketplace: capturing the value of ecosystem services.

Washington, D.C.: Island Press; Kareiva, Peter M. 2011. Natural capital: theory \& practice of mapping ecosystem services. Oxford [England]: Oxford University Press; LaRocco, Gina L., and Robert L. Deal. 2011. Giving credit where credit is due increasing landowner compensation for ecosystem services. Portland, OR: U.S. Dept. of Agriculture, Forest Service, Pacific Northwest Research Station. http://purl.fdlp.gov/GPO/gpo9767. All of these titles are clearly based upon economic liberalist approaches, approaches that I argue do nothing to challenge the inherent contradictions of the world capitalist system that are outlined in this paper. 
vulgar input/output kind of economic analysis that is far from the actually existing reality that ecosystems operate under.

After all of this analysis of the past, and our brief encounters with the present (if there really is such a thing for our purposes), we are left with the question of what might the future look like? If we put on our ecological futurist hat, we can argue that if we continue on the road we are on, we may likely end up where we are headed - the collapse of the global capitalist system. The global ecosystem, and particularly its smaller ecosystems of scale, is no match for the counter-revolutionary powers of the capitalist world-system, particularly in times of global stagnation. But then again, capitalism itself is a construct of the human mind, and a system of the human collective conscience, one that is simultaneously dependent upon ecological crises. In other words, our study of the Industrial Revolution shows us that capitalism, as a system for organizing all of nature (human and extra-human), has built within itself its own counter-revolution against its perceived revolutions of capital expansion. All we can do here is to admit that it is indeed possible to completely alter the way in which we humans interact with the rest of nature, and such changes have potentially profound consequences for how states, societies, and individuals interrelate within the larger web of life in the future.

The Green Revolutions continue and the drumbeat of cheapening the abstracting of ecological surpluses in the cause of capital accumulation bangs on without remorse. Nothing less than global antisysemic revolution against the capitalization of all of human and extra-human nature is needed if we are to stand a chance at coping with the inevitable march of the capitalist world-system toward mounting crises. "As opportunities for 
accumulation by appropriation contract, we would expect to see a profound shift from spatial to temporal fixes (Harvey 1989), moving from the appropriation of space to the colonization of time: the greatest strength of neoliberal financialization" (Moore 2013c), only the latest in the historical development of new tools of extraction and exploitation.

The 'vertical' expansion of the capital frontier, particularly coal, natural gas, and oil continues unabated in both the periphery and the core, only the core countries are running out of the drug regime necessary to continue life as we know it for the long term. Therefore, the 'horizontal' expansion also continues, and it is just as bloody and merciless as it has ever been. However, by first accepting that these expansion are in fact how historical capitalism has evolved over time and space, and then by attempting to merge our understandings of these methods of expansion, we begin to see things on the worldecological scale. The Four Cheaps (cheap labour-power, energy, resources, and materials) no longer can be maintained in the way they have for centuries. Monsanto, Cargill, Dow Chemical, and Koch Industries, among many others, sing a different tune, but that is not because they know better than us. It is a case of strategic engineering of public opinion at a level perhaps never seen before, for they manufacture the consent of the governed by literally bankrolling the levers of governance, looking more and more like what Sheldon Wolin calls inverted totalitarianism, where the private begins its dictatorship over the public (2008).

While reconciling the problem of 'Four Cheaps' seems increasingly difficult in the hyper-capitalized and financialized current world-economy, Moore suggests that looking at the 'cyclical rise and decline of the Four Cheaps' offers us a way to identify a 'point of 
entry into a deeper, world-ecological, understanding of historical capitalism' (2013c). My contribution to the opening of that doorway is by hopefully bringing into much sharper focus the ideation of 'the Industrial Revolution'. If we see industrialization as beginning many hundreds of moons before English society was anything but a free-riding shadow of the world-economy, and the period $1750-1850$ as a uniquely spirited drive by the captains of industry to accumulate unprecedented stores of capital - a drive still vociferously under way today - a window can be opened, shedding necessary sunlight upon the cruelly complex patterns of 'development' in the global East and South. As I wrote earlier, it is yet another BRIC in wall of industrial development.

The challenge mounted by this paper is against the dominant regimes of knowledge and truth that serve as sharp tools of reification for the global capitalist system, the Industrial Revolution being perhaps the most subversive historical construct of them all. It remains tragically under-examined, and therefore we must argue that further research must be conducted in this area, and not all of it need be theoretical. Industrialization is alive and well in what could call the new New World, but with this paper and the connected work of the world-ecology community, its controlling stake in our understanding of historical capitalism over the very long term can be overthrown by a new way of seeing capitalism not as merely an economic system, but a system for organizing every aspect of human and extra-human nature in service to capital accumulation. Closely, and critically examining the ongoing process of industrial revolution in Brazil, Russia (perhaps re-industrialization would be the operative term here), China, India, and increasingly South Africa, must be the next stage of this research. 
One cannot re-invent the wheel; only repeat the processes of its conception and realization, with the best possible outcome being another wheel, not likely a better one. The ongoing capitalist industrial revolution, or the Industrial Revolution, ought to become a key point of convergence for any worthy discussion of the political, social, economic, and ecological implications of putting together current and future social scientific puzzles. Perhaps what we have done here is simply show, in historical terms, that the capitalist world-system has reached its apex; that capitalism's cheap nature strategy is no longer viable, and that the future is a future of capitalistic decline. What remains to be adequately questioned, however, is what this might mean for the development of global anti-systemic movements away from this quickly sinking ship. In the next phase of this work, I intend to ask that very question, while analyzing the various ways in which resilience and human/nature co-evolution can exist free of seeing nature as man's free resource as both provider of all life and dustbin of all of the waste of capitalism's overproduction of commodities and underproduction of ecosystemic harmony. 


\section{RESOURCES}

Abel, W. 1980. Agricultural Fluctuations in Europe. New York: St. Martin's Press. Apter, David E. 1965. The Politics of Modernization. Chicago: University of Chicago Press.

Arrighi, Giovanni. 1994. The Long Twentieth Century: money, power, and the origins of our times. London: Verso 1998. "Capitalism and the Modern World-System: Rethinking the NonDebates of the 1970s. Review, 21 (1), 113-129. 2001. "Braudel, Capitalism, and the New Economic Sociology. Review, 24 (1), $107-123$. . 2002. "Lineages of Empire". Historical Materialism. 10 (3). . 2005. "Through the Prism of Slavery: Labour, Capital, and World Economy". American Journal of Sociology. 111 (3). . 2007a. "Globalization and the Race for Resources". Contemporary

Sociology. 36 (1). . 2007b. "States, Markets, and Capitalism, East and West". Positions.15 (2). . 2008. "Adam Smith and China: Lineages of the Twenty-First Century". Critical Asian Studies. 40 (2).

Ashton, T. S. 1948. The industrial revolution, 1760-1830. London: Oxford University Press.

Barham, Brad, Stephen G. Bunker, and Denis O'Hearn. 1994. States, firms, and raw materials: $\quad$ the world economy and ecology of aluminum. Madison, Wis: University of Wisconsin Press.

Barrett, W. 1990. "World Bullion Flows, 1450-1800," in The Rise of Merchant Empires, ed. J.D. Tracy, 224-54. Cambridge: Cambridge University Press. Barry, John. 2012. The politics of actually existing unsustainability: human flourishing in a climate- changed, carbon-constrained world. New York: Oxford University Press, USA.

Beales, H. L. 1958. The Industrial Revolution 1750-1850. New York: Augustus M. Kelley Bookseller, Reprints of Economic Classics.

Beard, Charles Austin. 1901. The Industrial Revolution. London: Swan Sonnenshein \& Co., Lim.

Benthall, Jonathan. 1974. The Limits of human nature; essays based on a course of lectures given at the Institute of Contemporary Arts, London. New York: Dutton. Berger, Peter L. 1986. The capitalist revolution: fifty propositions about prosperity, equality, and liberty. New York: Basic Books.

Bezanson, Anne. 1922. "The Early Use of the Term Industrial Revolution," Quarterly Journal of Economics 36, pp.343-49.

Blackburn, R. 1997. The Making of New World Slavery. London: Verso.

Bloch, M. 1961. Feudal Society (Vol. 1\&2) (L.A. Manyon, Trans.). Chicaco: University of Chicago Press. 
Bowditch, John, and Clement Ramsland. 1961. Voices of the industrial revolution. Ann Arbor: $\quad$ University of Michigan Press.

Brading, D.A. and H.E. Cross. 1972. "Colonial Silver Mining." Hispanic American Historical Review 52 (4): 545-79.

Braudel, Fernand. 1972a. The Mediterranean and the Mediterranean world in the age of Philip II, Volume I. New York: Harper \& Row.

.1972b. The Mediterranean and the Mediterranean world in the age of Philip

II, Volume II. New York: Harper \& Row.

1973. Capitalism and material life, 1400-1800. New York: Harper and Row. 1977. Afterthoughts on material civilization and capitalism (P.M. Ranum,

Trans.). Baltimore: Johns Hopkins University Press.

1981. The Structures of Everyday Life: the Limits of the Possible. (S. Reynolds,

Trans.) New York: Harper \& Row.

1982. Civilization and capitalism, 15th-18th century, Volume I. New York:

Harper \& Row.

1984. Civilization and Capitalism: 15th-18th Century, Volume III. New York:

Harper \& Row.

1993. A history of civilizations. New York, N.Y., U.S.A.: A. Lane.

Brenner, R. P. 1976. "Agrarian Class Structure and Economic Development in PreIndustrial Europe." Past \& Present, 70: 30-75.

Chew, S. 1997. "For Nature: Deep Greening World-Systems Analaysis for the 21st

Century," [electronic version]. Journal of World-Systems Analysis, 3 (3): 381-402. 2001. World-Ecological Degradation. Walnut Creek, CA: Alta Mira.

Chinn, Menzie D. and Jeffry A. Frieden. 2011. Lost Decades. New York: Norton. Cipolla, Carlo M. [1976] 1993. Before the Industrial Revolution: European society and economy, 1000- 1700. New York: Norton.

Cloke, Paul and Ron Johnston. 2005. Spaces of Geographical Thought. London: SAGE Publications.

Cobb, G., 1947. Potosí and Huancavelica. Economic Bases of Peru, 1545-1640. Ph.D. dissertation. Department of History, University of California, Berkeley.

Cole, J.A., The Potosí Mita, 1573-1700. Compulsory Indian Labour in the Andes.

Stanford, CA: Stanford University Press.

Coleman, D. C. 1956. "Industrial Growth and Industrial Revolutions, "Economica, n.s., XXIII, No. 89, 1-22. 1992. Myth, History and the Industrial Revolution. London: Hambledon Press.

Dean, Phillis. 1973. "The role of Capital in the Industrial Revolution," Explorations in Economic History, X, 3, 349-364. 1979. The First Industrial Revolution, 2nd ed. Cambridge, Engl.: Cambridge

University Press.

Diamond, J. 1997. Guns, Germs, and Steel: The Fates of Human Societies. New York:

Norton.

Dobson, Andrew. 2007. Green Political Thought. New York: Routledge.

Dowd, Douglas Fitzgerald. 1971. The state, power and the industrial revolution, 1750-

1914. [Ann Arbor, Mich.]: Union for Radical Political Economics. 
2000. Capitalism and its economics: a critical history. London: Pluto Press.

Dunn, R. S. 1972. Sugar and Slaves. New York: W.W. Norton.

Elvin, M. 2003. Retreat of the Elephants. New Haven, CT: Yale University Press. Engels, Frederich. 1975. The Housing Question. Moscow: Progress Publishers.

Eversley, D. E. C. 1967. "The Home Market and Economic Growth in England, 175080," in E. L. Jones \& G. E. Mingay, eds., Land, Labour and Population in the Industrial Revolution. London: Edward Arnold, 206-259.

FAO. 2002. World Agriculture. Towards 2015/2030. Rome: FAO.

FAO. 2009. "FAO Food Price Index (FFPI)" (http://maps.grida.no/go/graphic/faofood- price-index-ffpi) accessed 16 May 2014.

Fehér, Ferenc. 1990. The French Revolution and the birth of modernity. Berkeley: University of California Press.

Foster, John Bellamy. 2000. Marx's Ecology: materialism and nature. New York: Monthly Review Press.

2013. "Marx and the rift in the universal metabolism of nature". Monthly

Review. 65 (7): 1-19.

Foucault, Michel. 1977. Discipline and Punish. New York: Vintage Books. . 1982. "The Subject of Power," Critical Inquiry, Vol. 8, No. 4, pp. 777-795.

Fusfeld, David. 2002. The Age of the Economist. Boston: Pearson Education. Hall, Peter A. eds. 1989. The Power of Political Ideas: Keynesianism across Nations. Princeton: Princeton University Press.

Hartwell, R.M. 1967a. "Introduction," in R.M. Hartwell, ed., The Causes of the Industrial Revolution in England. London: Methuen, 1-30. .1967b. The causes of the Industrial Revolution in England. London: Methuen. 1967c. "The Causes of the Industrial Revolution: An Essay in Methodology," in $\quad$ R.M. Hartwell, ed., The Causes of the Industrial Revolution in England. rev. ed. London: The Historical Association. .1970. "The Great Discontinuity: Interpretations of the Industrial Revolution," Historical Journal (New South Wales), I, 3-16. . 1990. "Was There an Industrial Revolution?" Social Science History Vol. 14, No. 4 (Winter, 1990), pp. 567-576 Harvey, David. 1982. The limits to capital. London: Verso. 2003. The new imperialism. Oxford: Oxford University Press. 2006. David Harvey: A Critical Reader, Edited by Noel Castree and Derek Gregory. Malden, MA: Blackwell Publishing . 2010a. The enigma of capital: and the crises of capitalism. Oxford [England]: Oxford University Press. .2010b. A companion to Marx's Capital. London: Verso. 2013. A companion to Marx's Capital, Volume 2. London: Verso. Heaton, Herbert. 1932. "Industrial Revolution," Encyclopedia of the Social Sciences, Vol. VIII. New york: Macmillan, 3-13.

Hilton, Rodney. 1976a. Introduction. In R. H. Hilton (Ed.), The Transition from Feudalism to Capitalism (pp. 9-30). London: New Left Books. 
Himmelfarb, Gertrude. 1984. The idea of poverty: England in the early Industrial Age. New York: Knopf.

Hobsbawm, E. J. 1962. The Age of Revolution, 1789-1848. New York: Mentor. . [1968] 1999. Industry and Empire: The Birth of the Industrial Revolution.

New York: New Press.

Hopkins, Terence K., and Immanuel Maurice Wallerstein. 1996. The age of transition: trajectory of the world-system 1945-2025. London: Zed Books.

Hornborg, Alf, John Robert McNeill, and Juan Martínez Alier. 2007. Rethinking environmental history: world-system history and global environmental change.

Lanham: AltaMira Press.

Huber, Matthew T. 2013. Lifeblood Oil, Freedom, and the Forces of Capital.

Minneapolis: University of Minnesota Press.

http://public.eblib.com/EBLPublic/PublicView.do?ptiID=1362028.

Hornborg, Alf, John Robert McNeill, and Juan Martínez Alier. 2007. Rethinking

environmental history: world-system history and global environmental change. Lanham: AltaMira Press.

Hughs, J.D. 2001. An Environmental History of the World. New York: Routledge. Jackson, R. V. 1985. "Growth and Deceleration in English Agriculture, 1660-1790." Economic History Review, 38: 333-51.

Jensen, Derrick. 2006. Endgame. New York: Seven Stories Press.

Jones, E.L. 1987. The European Miracle: Environments, Economies, and Geopolitics in the History of Europe and Asia (2nd ed.). Cambridge, UK: Cambridge University Press.

Kaye, H. J. 1984. The British Marxist Historians. Cambridge, UK: Polity.

Knowles, L. C. A. 1926. The industrial and commercial revolutions in Great Britain during the nineteenth century. London: G. Routledge \& Sons.

Kuehls, Thom. 1996. Beyond Sovereign Territory. Minneapolis: University of Minnesota Press.

Lattimore, Own. 1955. "The Frontier in History," in Relazioni del X Congresso de

Science Storiche, I: Metodologia-Prolemi generali - Scienze ausiliare della storia.

Firenze, Italy: G.C. Sansoni.

Landes, David S. 1969. Prometheus Unbound. Cambridge: Cambridge University

Press.

1998. The Wealth and Poverty of Nations: Why some are so rich and some so

poor. New York: Norton.

Lefebvre, G. 1976. The Wealth and Poverty of Nations: Why some are so rich and some so poor. New York: Norton.

Lee, Richard E. 2012. The longue durée and World-Systems analysis. New York: State University of New York Press.

Lewontin, Richard and Rochard Levins. 2007. Biology Under the Influence: Dialectical Essays on Ecology, Agriculture, and Health. New York: Monthly Review Press. Luxemburg, Rosa. 1968. Accumulation of capital. New York: Modern Reader Press. 
Malanima, Paolo. 2006. "Energy crisis and growth 1650-1850: the European deviation in a comparative perspective." Journal of Global History 1 (March 2006): 101-121.

Malowist, M. 1958. "Poland, Russia, and the Western Trade in the 15th and 16th Centuries." $\quad$ Past \& Present, 13: 26-39.

Mantoux, Paul. 1928. The Industrial Revolution in the Eighteenth Century, 2nd rev. ed. London: Jonathon Cape. 1961. The industrial revolution in the eighteenth century: an outline of the beginnings of the modern factory system in England. London: Jonathon Cape. . 1973. Capital, Credit and Enterprise in the Industrial Revolution," Journal of European Economic History, II, 1, 121-143.

Marley, Ben and Samantha Fox. (Forthcoming). "Exhausting Socio-Ecological Relations: Conditions of Economic Viability in the Era of Mountaintop Removal in West Virginia"Journal of World-Systems Research. Marx, Karl and Friedrich Engels. [1888] 1964. The Communist Manifesto. New York: Pocket Books.

Publishers. [1847a] 1966. The Poverty of Philosophy. New York: International . [1847b] 1967a. Capital, Unabridged: A Critical Analysis of Capitalist Production, Volume One, Edited by Frederick Engels. New York: International Publishers New World Paperback. . [1939] 1973. The Grundrisse: Introduction to the Critique of Political Economy. Middlesex, $\quad$ England: Penguin Books Ltd. . [1847c] 1967b. Capital, Volume III, Edited by Frederick Engels. New York: International Publishers New World Paperback. . 1977. Capital, Vol. I. New York: Vintage. . [1972a] 1978a. "Economic and Philosophic Manuscripts of 1844." The MarxEngels Reader. Ed. Robert C. Tucker. New York: W.W. Norton \& Company, pp. 66125. [1972b] 1978b. "Theses on Feuerbach." The Marx-Engels Reader. Ed. Robert C. Tucker. New York: W.W. Norton \& Company, pp. 143-145. . [1972c] 1978c. "The Grundrisse." The Marx-Engels Reader. Ed. Robert C.

Tucker. New York: W.W. Norton \& Company, pp. 221-293. . [1972d] 1978d. "The German Ideology." The Marx-Engels Reader. Ed. Robert C. $\quad$ Tucker. New York: W.W. Norton \& Company, pp. 146-200. Mathias, Peter. 1969. The First Industrial Revolution. London: Methuen. McMichael, Phillip. 1997. "Rethinking Globalization." Review of International Political Economy, 4 (4): 630-62. .1998. "Global Food Politics." Monthly Review, 50 (3): 97-111. . 2008. "Global Development and the Corporate Food Regime." Research in Rural Sociology and Development, 11: 269-303. McNeill, J. R. 2000. Something New Under the Sun: An environmental history of the twentieth century. New York: Norton. 
Mokyr, Joel. 1990. The lever of riches: technological creativity and economic progress. New York: Oxford University Press.

Moore, Jason W.1997. "Capitalism over the Longue Duree: A Review Essay." Critical Sociology 23 (1997): 103.

.2000a. "Environmental Crises and the Metabolic Rift in World-Historical

Perspective." Organization \& Environment 13 (2000): 123.

2000b. "Sugar and the expansion of the early modern world-economy:

commodity frontiers, ecological transformation, and industrialization". Monthly

Review. 23 (2000)(3): 409-433.

2001a. "Capital, Territory, and Hegemony over the Longue Duree." Science \& Society. 65 (4) (2001): 476.

.2001b. "Globalization in Historical Perspective." Science \& Society. 65 (3)

(Fall 2001): 386.

. 2002a. "The Crisis of Feudalism: An Environmental History." Organization \& Environment 15 (3) (Sept 2002): 301-322.

2002b. "Remaking Work, Remaking Space: Spaces of Production and

Accumulation in the Reconstruction of American Capitalism, 1865-

1920". Antipode. 34 (2) (March 2002): 176.

. 2003a. "The Modern World-System as environmental history? Ecology and

the rise of capitalism". Theory \& Society. 32 (3) (June 2003): 307.

. 2003b. "Capitalism as World-Ecology: Braudel and Marx on Environmental

History." Organization \& Environment 16 (4) (Dec 2003): 431-458.

.2007. Ecology and the rise of Capitalism. Thesis (Ph.D. in Geography)--Univ.

of California, Fall 2007.

2008. "Ecological Crises and the Agrarian Question in World-Historical

Perspective". Monthly Review: An Independent Socialist Magazine. 60 (6) (Nov

2008): 54 .

2009a. "Madeira, sugar, and the conquest of nature in the "first" sixteenth century". Review : a Journal of the Fernand Braudel Center. 32 (4) (2009): 345-390.

.2009b. '"The Wilderness Has Been Taken from the Forests": Modes of

Extraction in the Making of the Modern World'. Paper presented at the first

Wrold Conference on Environmental History, Copenhagen, 3-7 August 2009.

.2009c. 'Ecology and the Accumulation of Capital: A Brief Environmental

History of Neoliberalism'. Paper presented at the conference 'Food, Energy,

and Environment. Crisis of the Modern World-System', Fernand Braudel Center,

Binghamton, New Hork, 9-10 October; available at http://jasonwmoore.com . 2010a. "Amsterdam is Standing on Norway, Part I: The Alchemy of Capital, Empire and Nature in the Diaspora of Silver, 1545-1648". Journal of Agrarian Change. 10 (1) (Jan 2010): 33.

2010b. "Amsterdam is Standing on Norway, Part II: The Global North

Atlantic in the Ecological Revolution of the Long Seventeenth Century". Journal of Agrarian Change. 10 (2) (April 2010): 188. 
. 2010c. "The End of the Road? Agricultural Revolutions in the Capitalist

World- $\quad$ Ecology, 1450-2010". Journal of Agrarian Change. 10 (3) (Jul 2010): 389.

2011a. "Transcending the Metabolic Rift: a theory of crises in the capitalist world- ecology." The Journal Peasant Studies 38 (1) (Jan 2011): 1-46.

.2011b. "Wall Street as a Way of Organizing Nature." Upping the Anti: A

Journal of Theory and Action, No. 12, May 2011, Toronto, Canada.

www.uppingtheanti.org.

. 2011c. "Ecology, Capital, and the Nature of Our Times," Journal of World-

Systems $\quad$ Analysis 17 (1), 108-47.

2012. "Cheap Food \& Bad Money." Review, 33 (2-3): 125-161.

. 2013a. "Anthropocene or Capitalocene? The Value of Nature and the Nature

of Value in the Capitalist World-Ecology," unpublished paper, Department of

Sociology, Binghamton University.

.2013b. "Metabolic Rift or Metabolic Shift? From Dualism to Dialectics in the

Capitalist World-Ecology," unpublished paper, Department of Sociology,

Binghamton University.

. 2013c. "The End of Cheap Nature: Or, How I Learned to Stop Worrying

about 'The' Environment and Love of the Crisis of Capitalism," unpublished paper, Department of Sociology, Binghamton University.

. 2014a. "Transcending the Epistemic Rift: Historical Capitalism and the

Restructuring of Nature," unpublished paper. Department of Sociology,

Binghamton University. 2014b. Ecology and the Accumulation of Capital. New York: Verso.

Mumford, J.R. 2004. Vertical Empire: The Struggle for Andean Space in the Sixteenth

Century. Ph.D. Dissertation. Department of History, Yale University.

Nef, John U. 1957. Industry and government in France and England, 1549-1640.

Ithaca, N.Y.: Great Seal Books.

Row. 1960. Cultural Foundations of Industrial Civilization. New York: Harper \&

1964. Conquest of the Material World: Essays on the Coming of Industrialism.

Cleveland: Meridian Books

O'Brien, Patrick. 1985. "Agriculture and the Home Market for English Industry, 1660-1820." English Historical Review, 100: 773-800.

O'Brien, Patrick and Caglar Keyder. 1978. Economic Growth in Britain and France

1780-1914. London: George Allen \& Unwin.

O'Connor, James. 1998. Natural Causes: Essays in Ecological Marxism. New York: The Guilford Press.

Overton, M. 1996. Agricultural Revolution in England. Cambridge: Cambridge

University Press.

Panitch, Leo. 2010. "Giovanni Arrighi in Beijing: An Alternative to

Capitalism?"Historical Materialism. 18 (1): 74-87.

Peck, Jamie. 2010. Constructions of neoliberal reason. Oxford: Oxford University Press. 
Plumb, J. H. 1950. England in the Eighteenth Century, Pelican History of England, Vol. 7. Harmondsworth, Engl.: Penguin.

Polanyi, Karl. 1944. The great transformation. New York: Farrar \& Rinehart, Inc. Polanyi, Karl, in collabouration with Abraham Rotstein. 1966. Dahomey and the Slave Trade. Seattle, WA: University of Washington Press.

Pomeranz, Kenneth. 2000. The great divergence: China, Europe, and the making of the modern world economy. Princeton, N.J.: Princeton University Press.

Portes, A. 1977. "Urban Latin America," in Urbanization in the Third World, eds. J. Abu- Lughod and R. Hay, Jr., 59-70. Chicago: Maaroufa.

Schroyer, Trent. 1971. "The Critical Theory of Late Capitalism," in Fisher, the Revival of American Socialism: Selected Papers of the Socialist Scholars Conference, ed. George Fisher (Oxford University Press, New York), pp. 297-321.

Scott, James C. 1998. Seeing like a state: how certain schemes to improve the human condition have failed. New Haven: Yale University Press.

Sella, D. 1974. "European Industries 1500-1700." In The Fontana Economic History of Europe II, ed. C.M. Cipolla, 354-426. New York: Fontan/Collins.

Shapiro, Ian. 1989. "Gross Concepts in Political Argument," Political Theory, Vol. 17, No. 51, pp. 51-76.

Sicking, L., H. de Bles and E. des Bouvrie, eds. 2004. Dutch Light in the 'Norwegian Night'. Hilversum: Uitgeverij Verloren.

Slicher van Bath, B. H. 1963. The Agrarian History of Western Europe, 500-1850 A.D. New York: St. Martin's Press.

Smith, Adam. [1776] 1955. An inquiry into the nature and causes of the wealth of nations. Chicago: Encyclopædia Britannica.

Smith, John Maynard. 1986. "Molecules Are Not Enough," review of The Dialectical Biologist, London Review of Books 6 (Feb).

Smith, N. 1984. Uneven Development. New York: Blackwell.

Sevetdal, H. and S. Grimstad. 2003. "Norwegian Commons: History, Status and Challenges." Paper presented to the First International Workshop on CoGovernance, University $\quad$ of Western Cape, South Africa, 7 October 2003.

Steffen, Will, Paul J. Crutzen, and John R. McNeill. "The Anthropocene: Are Humans Now Overwhelming the Great Forces of Nature," AMBIO: A Journal of the Human Environment, Vol. 36, No. 8, (2007): 614-621.

Taylor, Philip A. M. 1970. The industrial revolution in Britain: triumph or disaster? Lexington, Mass: $\quad$ Heath.

Thompson, Allan. 1973. The dynamics of the industrial revolution. New York: St. Martin's Press.

Tilly, C. 1984. Big Structures, Large Processes, Huge Comparisons. New York: Russell Sage.

1990. Coercion, Capital, and European States. Cambridge, MA: Blackwell. Tocqueville, Alexis De. [1835][1840] 2001. Democracy in America. New York, NY: Singnet Classic. Tomich, D. 1997. "World of Capital/Worlds of Labour: A Global Perspective," in J. R. Hall (Ed.), Reworking Class (pp. 287-311). Ithica, NY: Cornell University Press. 
Toynbee, Arnold. 1884. Lectures on the Industrial Revolution. London: Rivington Press.

1956. The industrial revolution. Boston: Beacon Press.

Unger, R. W. 1992. "The Tonnage Europe's Merchant Fleets 1300-1800." The American Neptune, 52 (4): 247-61.

Wallerstein, Immanuel Maurice. [1974] 2011. The Modern World-System I: Capitalist agriculture and the origins of the European world-economy in the sixteenth century. New York: Academic Press.

.1989. The Modern World-System III: The second era of great expansion of the capitalist world- economy, 1730-1840s. San Diego: Academic Press.

.1999. The end of the world as we know it: social science for the twenty-first

century. Minneapolis: University of Minnesota Press.

Press.

2004. World-systems analysis: an introduction. Durham: Duke University

White, Jr. Lynn. 1963. "What Accelerated Technological Progress in the Western Middle Ages?" in A. C. Crombie, ed., Scientific Change. New York: Basic Books. Williams, Eric. [1944] 1994. Capitalism and Slavery. North Carolina: The University of North Carolina Press.

Williams, Raymond. The Long Revolution [1961] 2011. Cardigan: Parthian. 1976. Keywords. New York: Oxford University Press.

2001. The Raymond Williams Reader. Edited by John Higgins. Oxford:

Blackwell Publishers.

Williams, William Appleman. 1980. Empire as a Way of Life. England: Oxford University Press.

Wolin, Sheldon S. 2008. Democracy incorporated: managed democracy and the specter of inverted totalitarianism. Princeton: Princeton University Press. Wrigley, E. A. 1987. People, cities, and wealth: the transformation of traditional society. Oxford, UK: Blackwell.

1988. Continuity, chance and change: the character of the industrial

revolution in England. Cambridge [England]: Cambridge University Press. .2004. Poverty, Progress, and Population. Cambridge: Cambridge University

Press.

.2010. Energy and the English Industrial Revolution. Cambridge: Cambridge

University Press.

Zerzan, John. 1999. Against Civilization: readings and reflections. Eugene, Or:

Uncivilized Books. 